\title{
Amino Acids Bearing Aromatic or Heteroaromatic Substituents as a New Class of Ligands for the Lysosomal Sialic Acid Transporter Sialin
}

\author{
Lilian Dubois, Nicolas Pietrancosta, Alexandre Cabaye, Isabelle Fanget, Cécile Debacker, \\ Pierre-André Gilormini, Patrick M. Dansette, Julien Dairou, Christophe Biot, Roseline Froissart, \\ Anne Goupil-Lamy, Hugues-Olivier Bertrand, Francine C. Acher, Isabelle McCort-Tranchepain,* \\ Bruno Gasnier,* and Christine Anne*
}

Cite This: J. Med. Chem. 2020, 63, 8231-8249

Read Online

ACCESS | Lill Metrics \& More | 期 Article Recommendations

Supporting Information

ABSTRACT: Sialin, encoded by the SLC17A5 gene, is a lysosomal sialic acid transporter defective in Salla disease, a rare inherited leukodystrophy. It also enables metabolic incorporation of exogenous sialic acids, leading to autoantibodies against $\mathrm{N}$-glycolylneuraminic acid in humans. Here, we identified a novel class of human sialin ligands by virtual screening and structure-activity relationship studies. The ligand scaffold is characterized by an amino acid backbone with a free carboxylate, an $N$-linked aromatic or heteroaromatic substituent, and a hydrophobic side chain. The most potent compound, 45 (LSP12-3129), inhibited $N$-acetylneuraminic acid 1 (Neu5Ac) transport in a

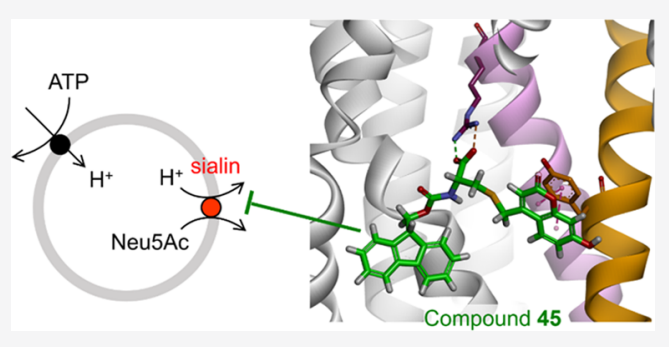
non-competitive manner with $\mathrm{IC}_{50} \approx 2.5 \mu \mathrm{M}$, a value 400 -fold lower than the $K_{\mathrm{M}}$ for Neu5Ac. In vitro and molecular docking studies attributed the non-competitive character to selective inhibitor binding to the Neu5Ac site in a cytosol-facing conformation. Moreover, compound 45 rescued the trafficking defect of the pathogenic mutant (R39C) causing Salla disease. This new class of cell-permeant inhibitors provides tools to investigate the physiological roles of sialin and help develop pharmacological chaperones for Salla disease.

\section{INTRODUCTION}

SLC17 transporters, a subgroup from the major facilitator superfamily (MFS) of secondary active transporters, are involved in the excretion of urate and other organic anions in the kidney, the uptake of anionic neurotransmitters (glutamate and ATP) into synaptic vesicles, and the export of sialic acids and acidic hexoses from lysosomes for reuse in metabolism. ${ }^{1-7}$ The latter function is ensured by sialin, a $\mathrm{H}^{+}$/ sialic acid symporter encoded by the SLC17A5 gene. ${ }^{5-7}$ Owing to its $\mathrm{H}^{+}$coupling and the steep $\mathrm{pH}$ gradient ( 2.5 units) across the lysosomal membrane, sialin actively exports sialic acids from the lysosomal lumen, thus contributing with de novo biosynthesis to their cytosolic availability. This in turn impacts the sialylation of cell surface glycoconjugates and their role in cell-cell, cell-extracellular matrix, and cell-pathogen interactions. Sialin has also been implicated in the uptake of nitrate at the plasma membrane ${ }^{8}$ and the uptake of aspartate, glutamate, and $\mathrm{N}$-acetyl-aspartyl-glutamate into synaptic vesicles. $^{9,10}$

In addition to its role in recycling endogenous sialic acids, lysosomal export by sialin enables the metabolic incorporation of exogenous sialic acids internalized by fluid-phase endocytosis, ${ }^{11}$ thus circumventing the absence of a sialic acid transporter at the plasma membrane. This endocytic route impacts human health by incorporating dietary-derived $\mathrm{N}$ glycolylneuraminic acid (Neu5Gc) into glycoconjugates.
Owing to a mutation in the cytidine monophosphateNeu5Ac hydroxylase (CMAH) gene, humans do not synthesize this sialic acid, which is abundant in other species. ${ }^{12}$ Neu5Gc is thus incorporated into human cell glycans, inducing the production of anti-Neu5GC autoantibodies associated with chronic inflammation, cancer, and atherosclerosis. ${ }^{13,14}$ This endocytic route is also exploited in glycoengineering approaches to alter cell-surface glycans with synthetic sialic acid derivatives and thereby modulate immune responses, inhibit pathogen binding, target toxins to tumors, or track cells in vivo after transplantation. ${ }^{15,16}$

The essential role of sialin in sialic acid homeostasis is also highlighted by its inactivation in two autosomal recessive genetic diseases, Salla disease and infantile free sialic acid storage disease (ISSD)..$^{5,17,18}$ Both diseases are associated with defective lysosomal export of sialic acids, ${ }^{6,7,19}$ leading to their accumulation in diverse tissues and their excretion in urine. However, they strongly differ in their clinical course and

Received: March 20, 2020

Published: July 1, 2020 
A
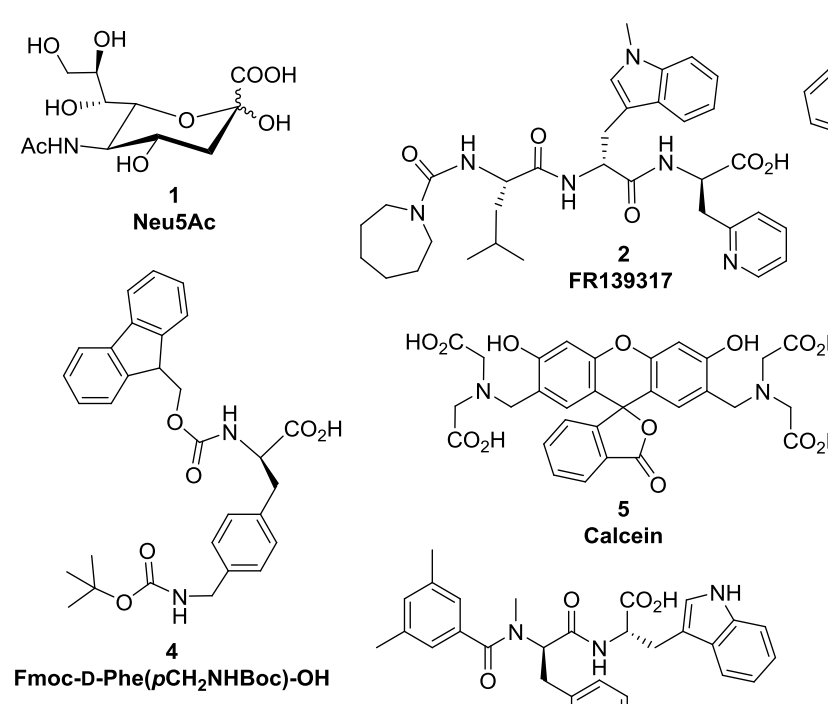

$\stackrel{2}{2}$<smiles>O=C(O)CN(CC(=O)O)Cc1cc2c(cc1O)Oc1cc(O)c(CN(CC(=O)O)CC(=O)O)cc1C21OC(=O)c2ccccc21</smiles><smiles></smiles>

Fmoc-Lys(Cbz)-OH<smiles>Cc1cc(C)cc(C(=O)N(C)C(Cc2ccc(-c3ccccc3)cc2)C(=O)NC(=O)Cc2ccccc2)c1</smiles><smiles>O=C(O)C1OCCOCCO[C@H](C(=O)O)[C@@H](C(=O)O)OCCOCCO1</smiles><smiles>CN(Cc1cnc2nc(N)nc(N)c2n1)c1ccc(C(=O)N[C@@H](CCC(=O)O)C(=O)O)cc1</smiles><smiles>NC(CCC(=O)NC(CSSCC(NC(=O)CCC(N)C(=O)O)C(=O)NCC(=O)O)C(=O)NCC(=O)O)C(=O)O</smiles><smiles>O=C(O)CN(CC(=O)O)c1ccccc1OCCOc1ccccc1N(CC(=O)O)CC(=O)O</smiles>

B
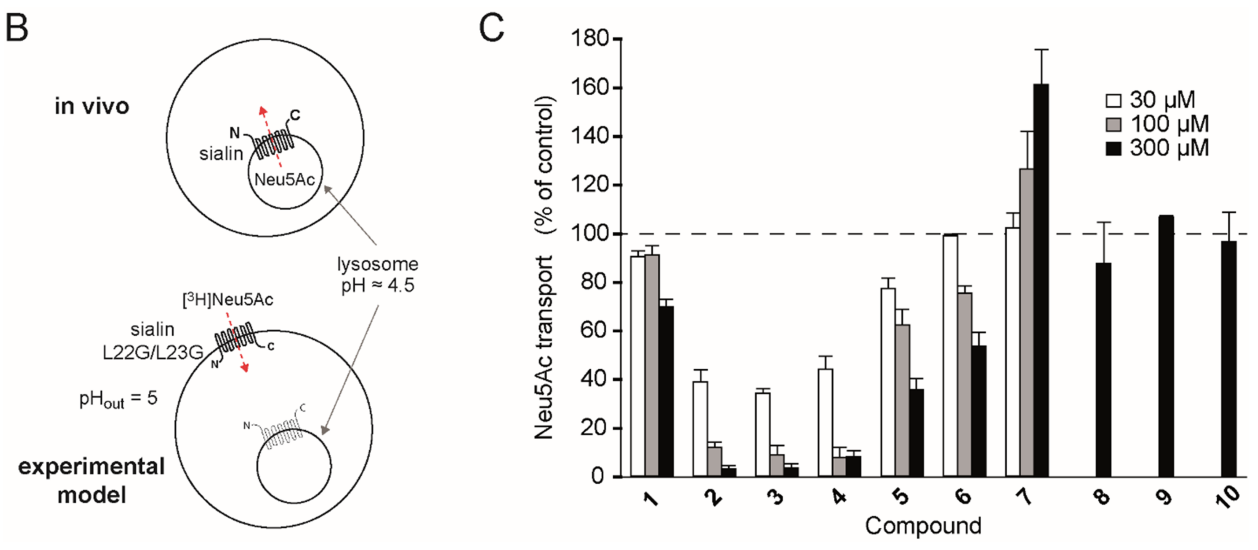

Figure 1. Identification of novel sialin inhibitors (A) structures ( 2 to 10$)$ of the best hits from a previous virtual screening. ${ }^{33}$ (B) Whole-cell assay of human sialin. Mutation of its lysosomal sorting motif redirects sialin to the plasma membrane to facilitate transport measurements. (C) Human sialin was assayed for $\left[{ }^{3} \mathrm{H}\right]$ Neu5Ac uptake at $\mathrm{pH} 5.0$ in the absence (control) or presence of these compounds (means \pm SEM of two to four independent experiments).

severity. While ISSD affects multiple organs from birth, causing death within a few months or years, Salla disease selectively affects the white matter of the brain in a progressive manner. ${ }^{17,20,21}$ Salla patients show hypotonia, ataxia, nystagmus, and delayed motor development during the first year. Psychomotor milestones, including speech, progressively worsen during infancy and childhood, leading to severe motor and cognitive deficits in adulthood. Magnetic resonance imaging shows nonspecific brain hypomyelination with a thinning of the corpus callosum. ${ }^{22}$ Current treatment is supportive.
The pathophysiology of Salla disease remains poorly understood. Sialin-defective mice studies have shown that brain hypomyelination results from defective maturation of oligodendrocytes. $^{23,24}$ However, the link between this defect and defective lysosomal sialic acid export or other transport activities of sialin ${ }^{9}$ (see ref 25) is unclear. Decreased downregulation of the polysialylated neural cell adhesion molecule (PSA-NCAM), which could delay oligodendrocyte/ axon contacts, may be involved. ${ }^{23}$ However, this decrease is limited, indicating that other mechanisms, such as impaired ganglioside metabolism, ${ }^{26}$ should contribute to the myelination defect. 
On the other hand, genotype-phenotype relationship studies have shown a clear correlation between the level of $\mathrm{Neu} 5 \mathrm{Ac}$ transport and the clinical severity induced by SLC17A5 mutations. Salla disease is almost exclusively associated with one missense mutation, R39C, in the homozygous or compound-heterozygous state, which partially impairs lysosomal targeting of $\operatorname{sialin}^{6,27}$ and decreases its transport activity to $\sim 20 \%$ of the wild-type level, ${ }^{6,7}$ whereas ISSD-associated mutations abolish either the expression or the transport activity of sialin. ${ }^{6,7,18}$ The association of Salla disease with residual sialic acid transport has been confirmed in a rare case of a patient with a homozygous K136E mutation, ${ }^{28}$ which also partially preserves sialic acid transport and lysosomal localization. ${ }^{6,-}$ The trafficking defect may result from destabilization of the $\mathrm{R} 39 \mathrm{C}$ and $\mathrm{K} 136 \mathrm{E}$ mutants and their retention by the protein quality control system. This feature along with the residual transport activity and the overwhelming predominance of the R39C mutation suggests pharmacological chaperone therapy as a promising option to treat Salla disease.

In contrast with other SLC17 transporters such as VGLUT $^{29-31}$ and VNUT $^{32}$ proteins, we lack pharmacological tools to study the cellular and physiological roles of sialin or to help rescue the R39C mutant causing Salla disease. In a previous study, ${ }^{33}$ we characterized the interaction of human sialin with synthetic sialic acids and identified one compound with $\mathrm{IC}_{50} \approx 40 \mu \mathrm{M}$, a value 25 -fold lower than the $K_{\mathrm{M}}$ for Neu5Ac. We also built a cytosol-facing homology model of human sialin based on a distantly homologous MFS crystallographic structure, the glycerol-3-phosphate transporter (GlpT) from Escherichia coli (E. coli). ${ }^{34}$ After validating the sialic acidbinding site of this model by site-directed mutagenesis, virtual screening against the ZINC database and Neu5Ac transport studies led us to identify the artificial tripeptide FR139317 as a new sialin ligand unrelated to sialic acids. ${ }^{33}$ In this study, we disclose other virtual hits from this screen and identify a novel scaffold of the sialin ligand well suited for chemical modifications. After optimization, the new ligands obtained inhibit sialin with a micromolar affinity in a non-competitive manner and one of them could partially rescue the trafficking defect of the pathogenic R39C mutant.

\section{RESULTS}

Screening and Scaffold Selection. Our previous virtual screening of a GlpT-based homology model of human sialin against a subset of the ZINC database ${ }^{35}(\sim 12,000$ compounds) identified the endothelin-A receptor antagonist FR139317 2 and eight other molecules ${ }^{33}$ (Figure 1A) as candidate sialin ligands. Transport studies confirmed 2 as a competitive inhibitor of $N$-acetylneuraminic acid 1 (Neu5Ac) transport by human sialin with a $K_{i}$ of $20 \mu \mathrm{M}$, a value $\sim 50$-fold lower than the $K_{\mathrm{M}}$ for Neu5Ac. ${ }^{33}$ We thus tested the other compounds using the same transport assay, which is based on a sorting mutant (L22G/L23G) redirected to the plasma membrane. ${ }^{6}$ In this approach, the poorly tractable lysosomal export is replaced by a whole-cell $\left[{ }^{3} \mathrm{H}\right] \mathrm{Neu}$ Ac uptake in acidic extracellular buffer to mimic the lysosomal lumen and facilitate transport measurements (Figure 1B). This technique provides higher signal-to-noise ratios than lysosomal assays with highly similar Neu5Ac transport properties. ${ }^{6}$

Among the novel virtual hits, four compounds inhibited Neu5Ac uptake and three of them, Fmoc-Lys (Cbz)-OH 3, Fmoc-D-Phe $\left(p \mathrm{CH}_{2} \mathrm{NHBoc}\right)-\mathrm{OH} 4$, and calcein 5 were more efficient inhibitors than Neu5Ac (Figure 1C). Interestingly, 3 and 4 are both amino acid derivatives with common features: the $\alpha$ amine is protected by the same hydrophobic carbamate, (fluoren-9-yl)methoxycarbonyl (Fmoc); the carboxylic acid is free; and a 4 to 6-carbon side chain bears a distal amine protected by a benzyloxycarbonyl (Cbz) or tert-butoxycarbonyl (Boc) group.

These similarities suggested a novel scaffold recognized by sialin. To test this hypothesis, we evaluated a series of $14 \mathrm{~N}$ Fmoc amino acids (11-24) in our transport assay (see structures in the Supporting Information, pp. S3-S4). N-Fmoc amino acids 11, 12, 16, 22, and 24 were prepared according to classical methods (see the Supporting Information), whereas compounds 13-15, 17-21, and 23 were commercially available. Interestingly, 10 out of 14 compounds inhibited Neu5Ac uptake with an efficiency greater than or similar to that of compounds 3 and 4 (Figure 2), thus confirming the

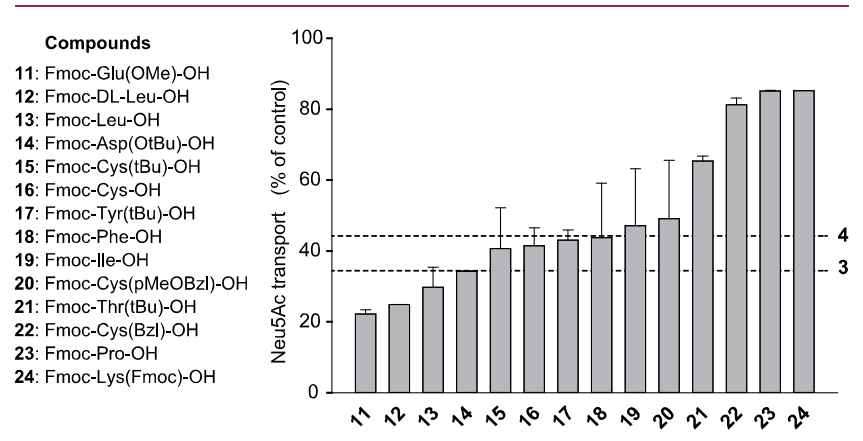

Figure 2. $N$-Fmoc amino acids $(30 \mu \mathrm{M})$ were tested for inhibition of human sialin as in Figure 1. The dotted lines correspond to the inhibition by compounds 3 and 4 .

existence of a novel scaffold characterized by an $N$-Fmoc group, a free carboxylate, and a hydrophobic side chain. The lower activity of compounds 22-24 may result from the presence of a bulkier side chain (compare Fmoc-Lys(Fmoc)$\mathrm{OH} 24$ with 3) or a constrained ring structure of the side chain in Fmoc-Pro-OH 23. All tested amino acids except Fmoc-DLLeu-OH 12 belonged to the L-series. Comparison of the racemic 12 and L-13 forms of Fmoc-Leu-OH suggests that the $\alpha$ carbon configuration is not critical to binding sialin (Figure 2).

To characterize further this sialin ligand scaffold, we examined the influence of the proximal amine substitution. The 9-fluorenylmethoxycarbonyl group of compound 3 was thus replaced by a coumarinyl, quinolinyl, xanthenyl, or anthracenyl group linked to the $\alpha$ amine by an amide or carbamate bond. In another set of compounds, we examined the influence of substituents attached to the side chain. For this purpose, we first introduced 4-methylcarbonylcoumarin instead of $\mathrm{Cbz}$ in compound 3 and then selected compound 16 among those with good activity to alter the side chain because the sulfanyl group allows alkylation with substituted coumarins in a metabolically stable manner (resistance to cytosolic and lysosomal hydrolases). The synthesis and biological activity of the resulting compounds are described in the following sections.

Chemistry. All 7-hydroxy, 4-substituted coumarins were synthetized via Pechmann condensation in good yields using either a Brønsted acid with resorcinol or Lewis acid with an aminophenol derivative (Scheme 1). Compounds 25-28 were prepared according to conventional methods with slight improvements $^{36-38}$ (see the Supporting Information). 
Scheme 1. Synthesis of Functionalized Coumarins ${ }^{a}$

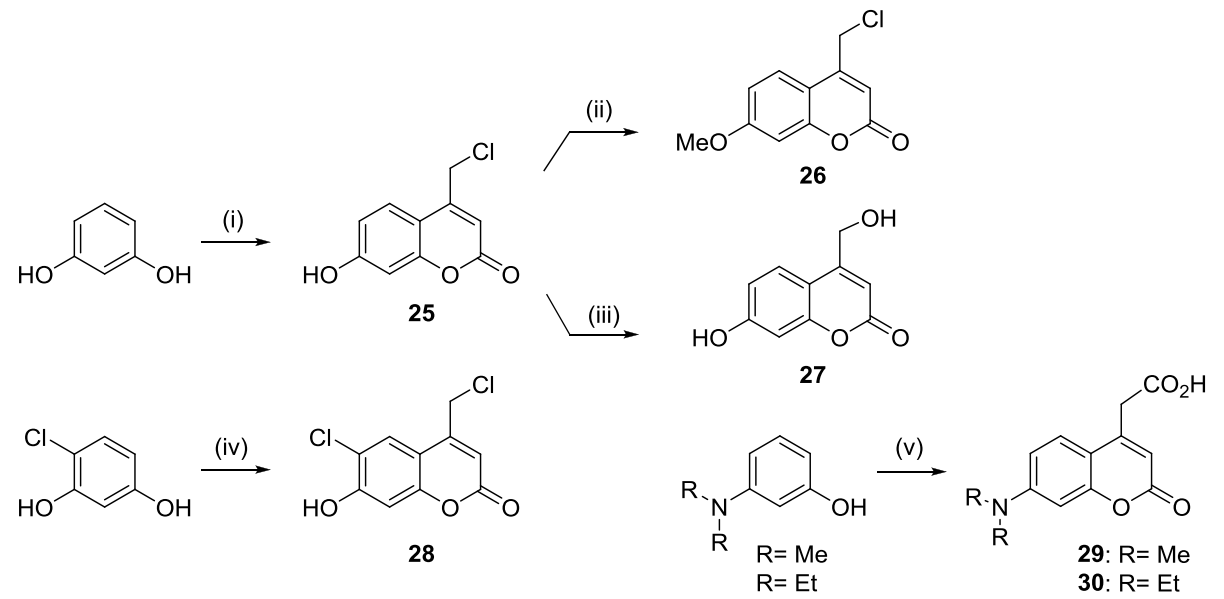<smiles>O=C(O)Cc1cc(=O)oc2c3c4c(cc12)CCCN4CCC3</smiles><smiles>O=C(O)CC=C1c2ccc(O)cc2Oc2cc(O)ccc21</smiles><smiles></smiles>

${ }^{a}$ Reagents and conditions: (i) ethyl-4-chloroacetoacetate, $70 \%$ aq $\mathrm{H}_{2} \mathrm{SO}_{4}, 0{ }^{\circ} \mathrm{C}, 1.5 \mathrm{~h}, 97 \%$; (ii) $\mathrm{K}_{2} \mathrm{CO}_{3}$, acetone, $\mathrm{Me}_{2} \mathrm{SO}_{4}, \mathrm{RT}$, overnight, $94 \%$; (iii) $\mathrm{H}_{2} \mathrm{O}$, reflux, 48 h, 69\%; (iv) ethyl-4-chloroacetoacetate, $\mathrm{CH}_{3} \mathrm{SO}_{3} \mathrm{H} \mathrm{RT}, 4 \mathrm{~h}, 97 \%$; (v) (a) ClTi( $\mathrm{OiPr}$ ) , dimethyl 3-oxoglutarate, toluene, reflux, overnight; (b) $\mathrm{NaOH}, \mathrm{MeOH}, \mathrm{RT}$, overnight, $35-66 \%$ (two steps); (vi) succinic anhydride, $70 \%$ aq $\mathrm{H}_{2} \mathrm{SO}_{4}, 140{ }^{\circ} \mathrm{C}, 4 \mathrm{~h}, 92 \%$; (vii) $\mathrm{MOM}-\mathrm{Cl}$, DIEA, $\mathrm{CH}_{2} \mathrm{Cl}_{2}, 0{ }^{\circ} \mathrm{C}, 45$ min, $71 \%$; (viii) Fmoc-Cl, pyridine, RT, $2 \mathrm{~h}, 34 \%$; and (ix) TFA, $\mathrm{CH}_{2} \mathrm{Cl}_{2}, 0{ }^{\circ} \mathrm{C}$ then RT, $1.5 \mathrm{~h}, 83 \%$.

Using chlorotriisopropoxytitanium(IV) ${ }^{39}$ was more efficient than zinc(II) chloride ${ }^{40}$ for the synthesis of 7-(dialkylamino)coumarins 29 and 30 . The xanthenyl derivative 32 was obtained according to a known procedure $e^{41}$ as the $3-(3,6-$ dihydroxy- $9 H$-xanthen-9-ylidene)propionic acid tautomer, unambiguously shown by NMR in aprotic solvent (DMSO).

Regioselective protection of the 7-hydroxy-4-hydroxymethylcoumarin 27 with methoxymethyl chloride before introducing the $9 H$-fluoren-9-yl methyl carbonate in the benzylic position and deprotection of the 7-hydroxyl led to 35 .

Amide bond formation between the amine of a lysine-OMe derivative and acids 29-32 as well as commercially available 7hydroxy-4-carboxymethylcoumarin and 4-carboxyquinolin-2one was carried out ${ }^{42}$ (Scheme 2). Attempts to condense previously activated 7-hydroxy-4-carboxymethylcoumarin as an acid chloride or HOBt ester in the presence of EDC with Lys ( $\mathrm{Cbz}$ )-OMe failed. In contrast, amide bond formation occurred in the presence of HBTU and HOBt via uronium salt activation ${ }^{43,44}$ with this 4-carboxymethylcoumarin or xanthene 32, leading to, after saponification of the methyl ester, 36 and $\mathbf{4 0}$ in poor yields (19 and 8\%, respectively). The condensation of 29, 30, 4-carboxyquinolin-2-one, and 31 with $\mathrm{Lys}(\mathrm{Cbz})-\mathrm{OMe}$ performed in the presence of HBTU in $\mathrm{CH}_{2} \mathrm{Cl}_{2}$ also led to the expected products, generally in better yields $(12-50 \%){ }^{45}$ In contrast, under these conditions, the coupling of 29 to the distal amine of lysine 43 was poorly efficient (5\%, not optimized). The carbamate analogue 44 of 36 was obtained from 27 with carbonyl diimidazole activation.
Alkylation of Fmoc-Cys-OH by coumarins 25, 26, and 28 proceeded at room temperature overnight in the presence of an excess of base to give compounds $45-47$ at approximately $30 \%$ yields (Scheme 3 ).

Structure-Activity Analysis of the Heterocycle-Substituted Amino Acids. Compounds 35-42 and 44 (see structures in the Supporting Information, pp. S3-S4) were tested in our whole-cell assay of sialin at $30 \mu \mathrm{M}$ (Figure 3) as for the Fmoc-amino acids 11-24. When 9-fluorenylmethyl carbonate is directly linked to coumarin 27 , the resulting compound 35 does not significantly inhibit sialin, showing that removal of the amino acid backbone and free carboxylate abolishes binding. Replacing the 9-fluorenylmethyl carbamate linked to the $\alpha$ amine in 3 by diverse heterocycles in compounds 36-41 reduced activity, ranging from a moderate loss with the bulky coumarin derivative 41 to virtually no inhibition with the quinolinyl compound 39. No significant difference was observed among coumarinyl derivatives 36-38 bearing different substituents at the 7-position (hydroxy, dimethyl, or diethylamino). Of note, when the amide bond of 36 was converted into a more flexible carbamate bond in $\mathbf{4 2}$, the affinity for sialin increased to a level similar to that of compound 3.

The influence of substituting the side chain was tested in compounds 44-47. Replacing the benzyloxycarbonyl group present in 3 by a substituted coumarin in 44 did not significantly alter activity. In contrast, the Fmoc-Cys(substituted coumarin)-OH 45-47 had better activities than the cysteine analogue Fmoc-Cys $(p \mathrm{MeOBzl})-\mathrm{OH} 20$ (Figure 3, 
Scheme 2. Synthesis of $N$-Acyl and $N$-Carbamate Diprotected Lysine ${ }^{a}$

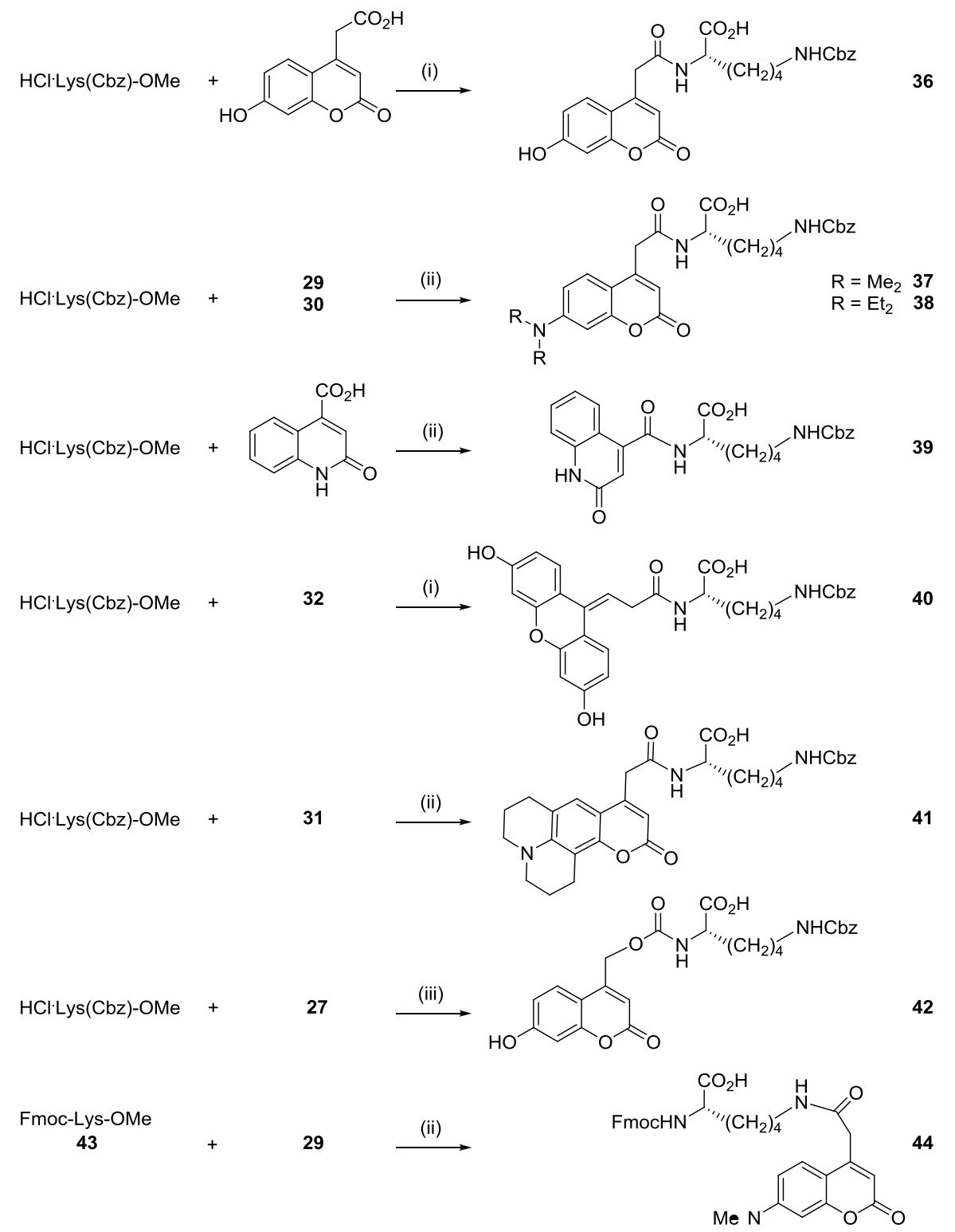

${ }^{a}$ Reagents and conditions: (i) (a) HBTU, HOBt, DMF, DIEA, RT, overnight and (b) aq LiOH, THF, RT, 2 h, 19\% for 36, $8 \%$ for 40 (two steps); (ii) (a) HBTU, $\mathrm{CH}_{2} \mathrm{Cl}_{2}$, DIEA, RT, $2 \mathrm{~h}$ and (b) aq LiOH, THF, RT, $2 \mathrm{~h}, 50 \%$ for 37, 19\% for 38, 43\% for 39, 12\% for 41, 5\% for 44 (two steps); (iii) (a) CDI, DMF, DIEA, RT then $80{ }^{\circ} \mathrm{C}, 1.5 \mathrm{~h}, 21 \%$ and (b) aq LiOH, THF, RT, $2 \mathrm{~h} 21 \%$ (two steps).

\section{Scheme 3. Synthesis of S-Alkyl Cysteine ${ }^{a}$}

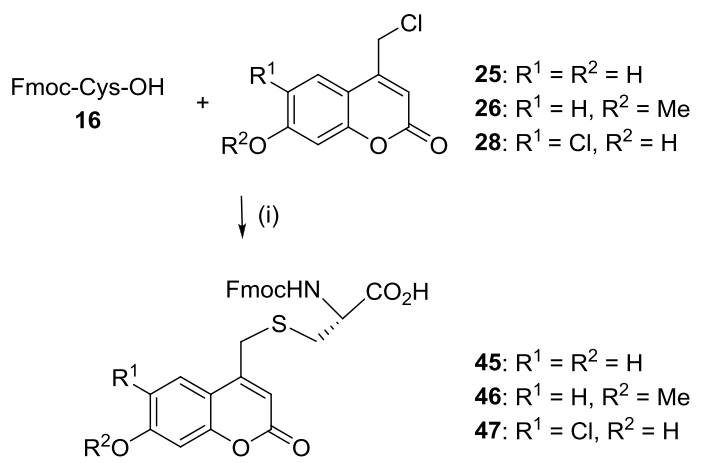

${ }^{a}$ Reagents and conditions: (i) from 25 and 28; DIEA, THF, RT, $16 \mathrm{~h}$, 35 and $32 \%$, respectively; from $26: \mathrm{Et}_{3} \mathrm{~N}, \mathrm{DMF}, \mathrm{RT}, 16 \mathrm{~h}, 28 \%$. red dotted line) or the lysine analogue 3 (brown line), showing that the length of the side chain is not critical to recognition.

The most active compounds 11, 13, and 45-47 inhibited Neu5Ac uptake by sialin in a concentration-dependent manner (Figure 4) in agreement with a specific interaction. FmocCys[Coum-7-OH]-OH 45 (LSP12-3129) was the most potent inhibitor with an $\mathrm{IC}_{50}$ of $2.4 \pm 0.7 \mu \mathrm{M}(n=3)$, a value $\sim 400$ fold lower than the $K_{\mathrm{M}}$ for Neu5Ac. ${ }^{33}$ To assess its selectivity, compound 45 was tested on two other $\mathrm{H}^{+}$-driven lysosomal transporters, LYAAT1 and cystinosin, measured in whole-cell assay similar to that of sialin. ${ }^{46,47}$ Interestingly, it had no effect on LYAAT1 and partially inhibited cystinosin (43.7 $\pm 9.1 \%$ inhibition, $n=3)$ at a concentration $(30 \mu \mathrm{M})$ that fully inhibits sialin (Figure 4C,D).

Compounds 45 and 13 (Fmoc-Leu-OH) Are Noncompetitive Inhibitors. We next studied how 45 and, for comparison, 13 (Fmoc-Leu-OH) interact with human sialin. 


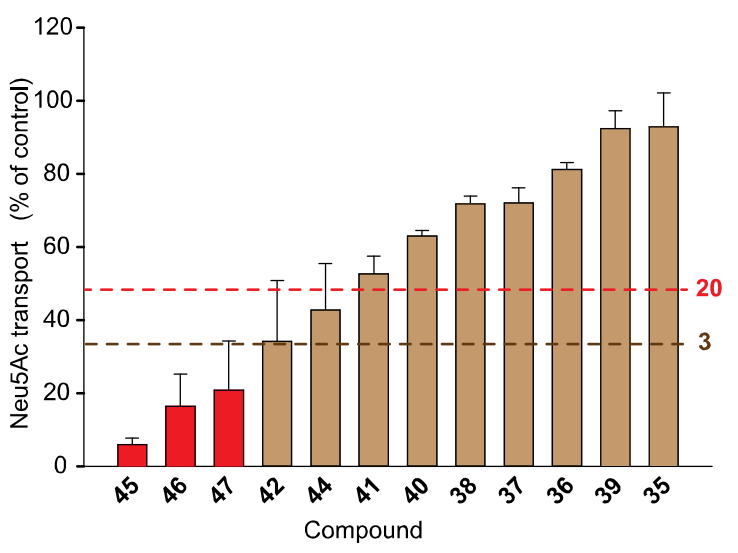

Figure 3. Screening of heterocycle-substituted amino acids. Compounds $(30 \mu \mathrm{M})$ were tested for inhibition of human sialin as in Figure 1. Each derivative is colored according to and compared with (dotted lines) its reference compound, 3 (brown) or 20 (red).

Fmoc-Leu-OH was chosen because it efficiently inhibits Neu5Ac uptake (Figure 4B; $\mathrm{IC}_{50}=23.3 \pm 3.5 \mu \mathrm{M}, n=4$ ) and is commercially available as a radiolabeled compound. Of note, Fmoc-Leu-OH had limited effects on LYAAT1 and cystinosin at a concentration $(100 \mu \mathrm{M})$ that fully inhibits sialin (Figure 4C,D). We first asked whether these compounds are substrates (translocated ligands) or blockers (not translocated) of the lysosomal transporter. When sialin-expressing cells (EGFP-Sialin L22G/L23G construct) and mock cells (EGFP) were incubated with $\left[{ }^{3} \mathrm{H}\right] \mathrm{Neu} 5 \mathrm{Ac}$ or $\left[{ }^{3} \mathrm{H}\right]$ Fmoc-Leu-OH at similar saturation levels $\left(\mathrm{IC}_{50} / 10,100\right.$ and $2 \mu \mathrm{M}$, respectively), no sialin-dependent $\left[{ }^{3} \mathrm{H}\right]$ Fmoc-Leu-OH uptake could be detected in acidic medium in contrast with the strong $\left[{ }^{3} \mathrm{H}\right] \mathrm{Neu} 5 \mathrm{Ac}$ uptake signal (Figure S1). Fmoc-Leu-OH thus acts as a blocker of sialin rather than a translocated substrate.

To extend these experiments to 45, we developed another whole-cell assay where sialin activity is detected by the cotransport of $\mathrm{H}^{+}$. We co-expressed the ratiometric fluorescent $\mathrm{pH}$ probe $\mathrm{E}^{2} \mathrm{GFP}^{48}$ with an mRFP-tagged human sialin L22G/ L23G construct in HEK293 cells to detect the cytosolic acidification associated with the uptake of sialin substrates. Neu5Ac $(10 \mathrm{mM})$ applied at $\mathrm{pH} 5.5$ induced a significant $\mathrm{E}^{2} \mathrm{GFP}$ fluorescence response consistent with the expected acidification. In contrast, a saturating concentration $(30 \mu \mathrm{M})$ of $\mathbf{4 5}$ did not induce any detectable acidification (Figure S2). Therefore, neither Fmoc-Leu-OH nor $\mathbf{4 5}$ is significantly translocated by human sialin, implying that they both act as blockers.

We next determined the inhibition mode of these compounds and studied the saturation kinetics of $\left[{ }^{3} \mathrm{H}\right] \mathrm{Neu} 5 \mathrm{Ac}$ uptake at varying inhibitor concentrations. Unexpectedly, despite the "active site" focus of our initial virtual screening, both Fmoc-Leu-OH and $\mathbf{4 5}$ acted as non-competitive rather than competitive inhibitors since they decreased the $V_{\max }$ of uptake while leaving the $K_{\mathrm{M}}$ for Neu5Ac essentially unchanged (see representative experiments in Figure 5A,B). At $10 \mu \mathrm{M}$, Fmoc-Leu-OH decreased $V_{\max }$ by $56 \pm 5 \%(n=5$ independent

\section{A}

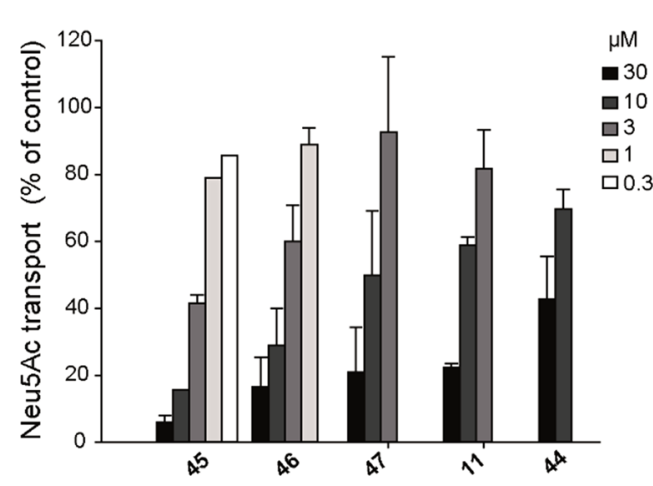

B

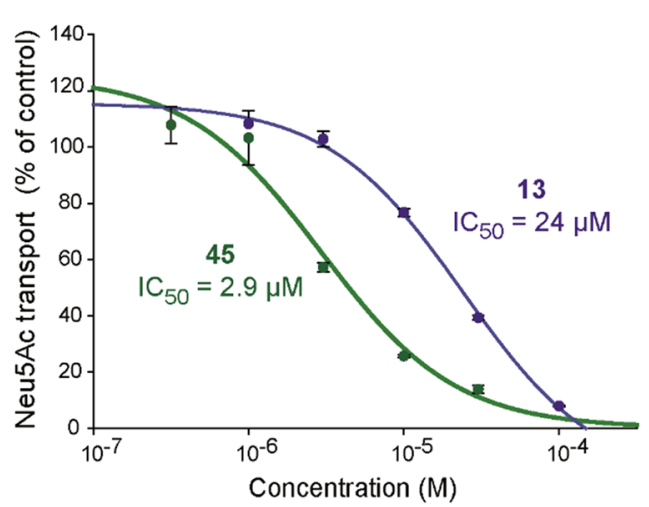

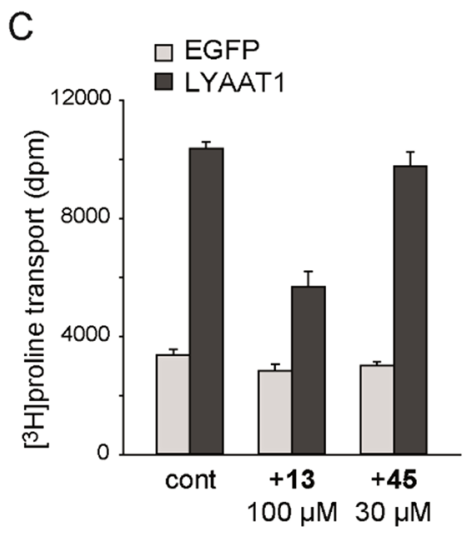

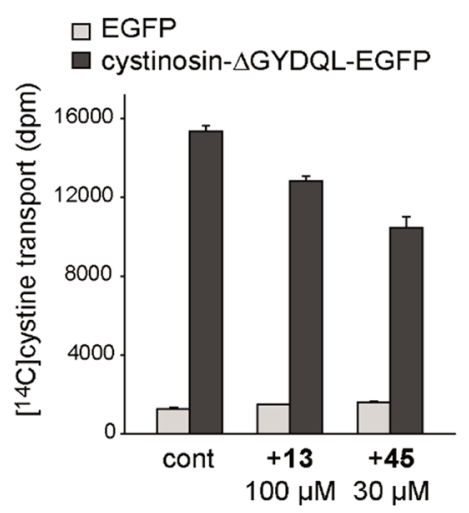

$\mathrm{D}$

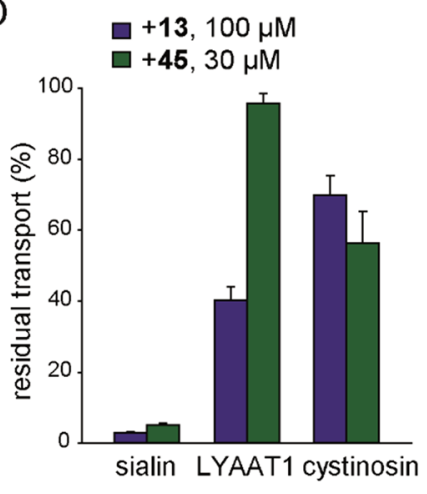

Figure 4. Dose-response relationship and selectivity of selected compounds. (A) Inhibition of human sialin. Means \pm SEM of two to three independent experiments. (B) Representative sialin inhibition curves for compounds $\mathbf{1 3}$ (blue) and $\mathbf{4 5}$ (green) (triplicate measurements). (C, D) Effect of 13 and 45 on two other $\mathrm{H}^{+}$-driven transporters, LYAAT1 and cystinosin. (C) Representative experiments (triplicate measurements). (D) Means \pm SEM of three independent experiments where the three transporters were assayed in parallel. 
A

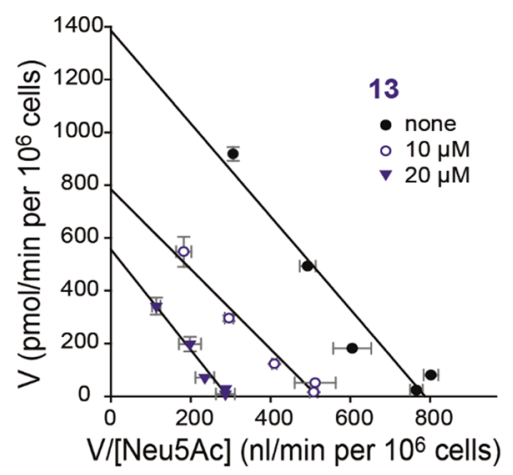

B

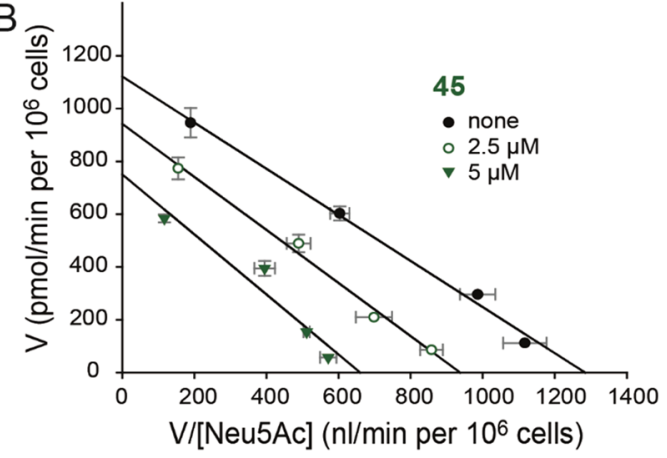

C

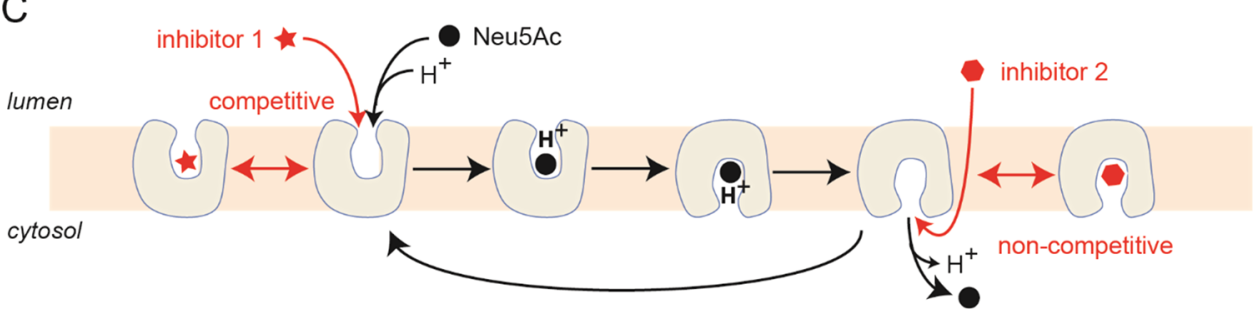

Figure 5. Inhibition mode of Fmoc-Leu-OH and 45. (A, B) Representative Eadie-Hofstee graphs (left) of $\left[{ }^{3} \mathrm{H}\right]$ Neu5Ac uptake saturation kinetics in the presence or absence of Fmoc-Leu-OH 13 and 45 (means \pm SEM of triplicate measurements). The reciprocal maximal velocity is plotted against the inhibitor concentration (right graphs) to determine inhibition constants. (C) Potential mechanism accounting for the non-competitive inhibition by aromatic $\mathrm{N}$-substituted amino acids (inhibitor 2). Black arrows depict the Neu5Ac transport cycle in our assay. Red arrows depict two inhibition mechanisms.

experiments) with $K_{\mathrm{M}}$ values of $1.6 \pm 0.3$ and $1.3 \pm 0.2 \mathrm{mM}$ in the absence and presence of inhibitors, respectively. Similarly, $45(3 \mu \mathrm{M})$ decreased $V_{\max }$ by $31 \pm 8 \%(n=3)$ with $K_{\mathrm{M}}$ values of $1.4 \pm 0.5$ and $1.7 \pm 0.5 \mathrm{mM}$ in the absence and presence of inhibitors, respectively. Mean $K_{i}$ values of $10.2 \pm 3.0 \mu \mathrm{M}(n=$ $3)$ and $7.8 \pm 1.8 \mu \mathrm{M}(n=4)$ were obtained for Fmoc-Leu-OH and 45 , respectively.

Potential Mechanism for the Non-competitive Inhibition. Conceivably, the non-competitive inhibition by Fmoc-Leu-OH and $\mathbf{4 5}$ could reflect a decrease in the $\mathrm{H}^{+}$ electrochemical gradient driving Neu5Ac uptake by sialin. However, the lack of an effect of 45 on LYAAT1 and the moderate inhibition of cystinosin by Fmoc-Leu-OH (Figure 4C,D) ruled out this possibility. As our virtual screening was conducted on a cytosol-facing model of sialin, ${ }^{33}$ we reasoned that the lack of competition between Neu5Ac, on one hand, and $\mathbf{4 5}$ or Fmoc-Leu-OH, on the other hand, might result from a selective blockade of sialin in the cytosol-facing state. Like any secondary active transporter, ${ }^{49,50}$ sialin should operate through alternating-access structural transitions, which expose the substrate-binding site to either the luminal (extracellular in our assay) or cytosolic side of the membrane. ${ }^{51}$ If an inhibitor binds to the NeuSAc-binding site of the outward-facing conformation (Figure 5C, inhibitor 1), the inhibitor and Neu5Ac should exclude each other and an excess of Neu5Ac should displace the inhibitor binding equilibrium and rescue inhibition. In contrast, if the inhibitor permeates the cell membrane (for instance, by diffusing across the lipid bilayer) and binds to the inward-facing state, the competition between Neu5Ac (on the extracellular side) and the inhibitor (on the cytosolic side) should be biased toward inhibitor binding (Figure 5C, inhibitor 2) because structural transitions are much slower than binding equilibriums: when the cytosolic inhibitor dissociates, the protein in the apo, inward-facing state will rebind with another inhibitor molecule before it can switch to the apo, outward-facing state. Extracellular Neu5Ac thus cannot displace the inhibitor binding equilibrium in this case, resulting in non-competitive inhibition. The non-competitive inhibition of sialin by Fmoc-Leu-OH and $\mathbf{4 5}$ may thus result from their selective or preferential binding to the cytosol-facing state. It may be noted that Fmoc-Leu-OH does enter cells in a sialin-independent manner (Figure S1), enabling its action on the cytosolic side of the transporter.

We used two approaches to test this model. First, we examined how fast sialin recovers its transport activity upon washing of $\mathrm{N}$-substituted amino acid inhibitors. If these 
inhibitors act on the extracellular side, washing should quickly restore Neu5Ac transport. On the contrary, if they predominantly act on the cytosolic side, recovery should be rate-limited by the cellular efflux of cytosolic inhibitors. Cells expressing sialin at the plasma membrane were thus preincubated with Neu5Ac or $N$-substituted amino acids at $\mathrm{pH}$ 5.0, washed at neutral $\mathrm{pH}$, and tested for $\left[{ }^{3} \mathrm{H}\right] \mathrm{Neu} 5 \mathrm{Ac}$ uptake at $\mathrm{pH} 5.0$ in the absence of inhibitors. For comparison, another set of cells was inhibited during $\left[{ }^{3} \mathrm{H}\right] \mathrm{Neu}$ SAc uptake as done previously. When this protocol was applied to Neu5Ac 1, the neutral wash fully restored $\left[{ }^{3} \mathrm{H}\right] \mathrm{Neu} 5 \mathrm{Ac}$ transport to a level (130\%) above that of the uninhibited control, probably reflecting the trans-stimulation of sialin by the cytosolic pool of Neu5Ac that accumulated during the pre-incubation step (see ref 52 for a similar trans-stimulation in lysosomal membrane vesicles). In contrast, when sialin was pre-inhibited by FmocLeu-OH or 45, only partial recovery was achieved after a 15 min wash (55 or $49 \%$ persisting inhibition, respectively) (Figure 6), in agreement with our hypothesis of the action on
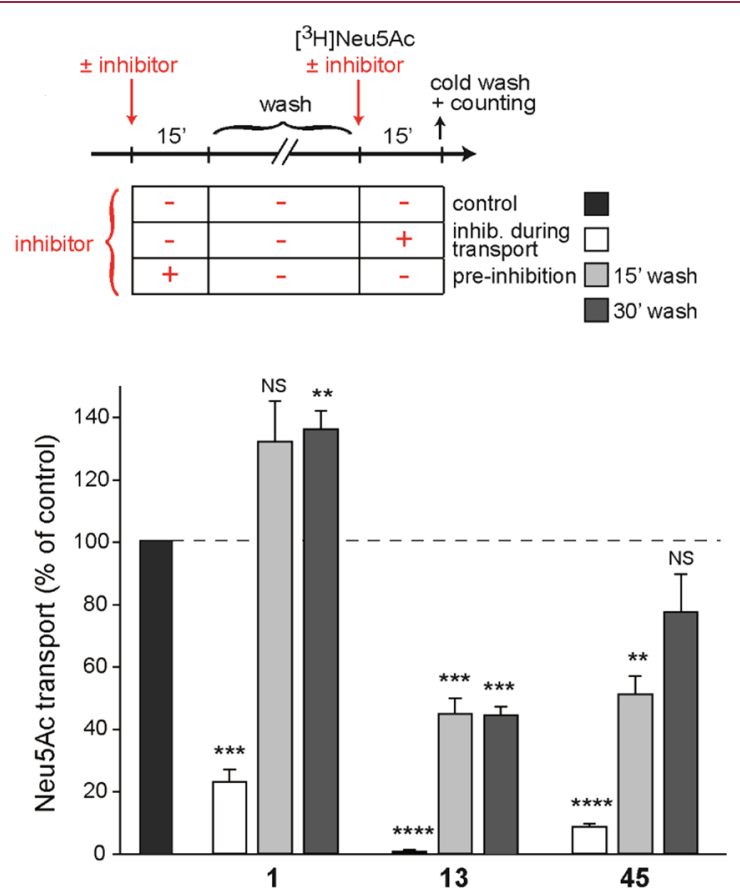

Figure 6. Persistence of 13- and 45-induced inhibition upon washing. HEK293 cells expressing sialin at the plasma membrane were preincubated or not with Neu5Ac 1 (5 mM), Fmoc-Leu-OH 13 (120 $\mu \mathrm{M})$, or $45(12 \mu \mathrm{M})$ for $15 \mathrm{~min}$ at $\mathrm{pH}$. After a 15 or $30 \mathrm{~min}$ wash at $\mathrm{pH} 7$ at room temperature, $\left[{ }^{3} \mathrm{H}\right] \mathrm{Neu} 5 \mathrm{Ac}$ uptake was measured and compared to the signals obtained in the absence or presence of competitors at the same concentrations (means \pm SEM of four independent experiments). $t$-Test relative to control: $* *=p<0.01$; $* * *=p<0.001 ; * * * *=p<0.0001$; NS, $\geq 0.05)$.

the cytosolic, rather than the extracellular, side of the transporter. Of note, when this experiment was repeated with FR139317 2, which inhibits sialin in a competitive manner, $^{33}$ the $15 \mathrm{~min}$ wash fully restored [3H]Neu5Ac transport without trans-stimulation (Figure S3). The competitive versus noncompetitive nature of sialin inhibitors thus correlates with the rate of Neu5Ac transport recovery upon washing, in agreement with an action on distinct sides of the membrane. The lower lipophilicity of FR139317 $(\log P=2.29$ in the protonated state) as compared to Fmoc-Leu-OH and 45
( $\log P=4.1$ and 3.91 , respectively) is also consistent with this model.

Second, we examined the docking of 45 to a novel 3D homology model of human sialin based on a closer template. Very recently, two crystal structures of $E$. coli $\mathrm{H}^{+} / \mathrm{D}$-galactonate symporter (DgoT) in outward-facing occluded and inwardfacing open conformations have been determined. ${ }^{51}$ Dgo $\mathrm{T}$ is a closer homologue of human sialin $(25.5 \%$ sequence identity and $45.0 \%$ similarity over 420 amino acids; BlastP alignment) than E. coli GlpT (21.0\% identity and 37.9 similarity over 309 amino acids). Moreover, the DgoT structures have a higher resolution and better global model quality estimation than the GlpT structure. ${ }^{34,51}$ Accordingly, we built two new sialin homology models based on the inward-facing open (6E9N) and outward-facing occluded (6E9O) conformations of DgoT and performed docking experiments with flexible side chains located at the potential binding site using GOLD software ${ }^{53}$ as implemented in Discovery Studio 2019.

45 could not be docked to the outward-facing occluded sialin model because the binding site was too small to accommodate the inhibitor. In contrast, 45 was well accommodated in the binding site of the inward-facing model (Figure 7A), providing a putative structural explanation
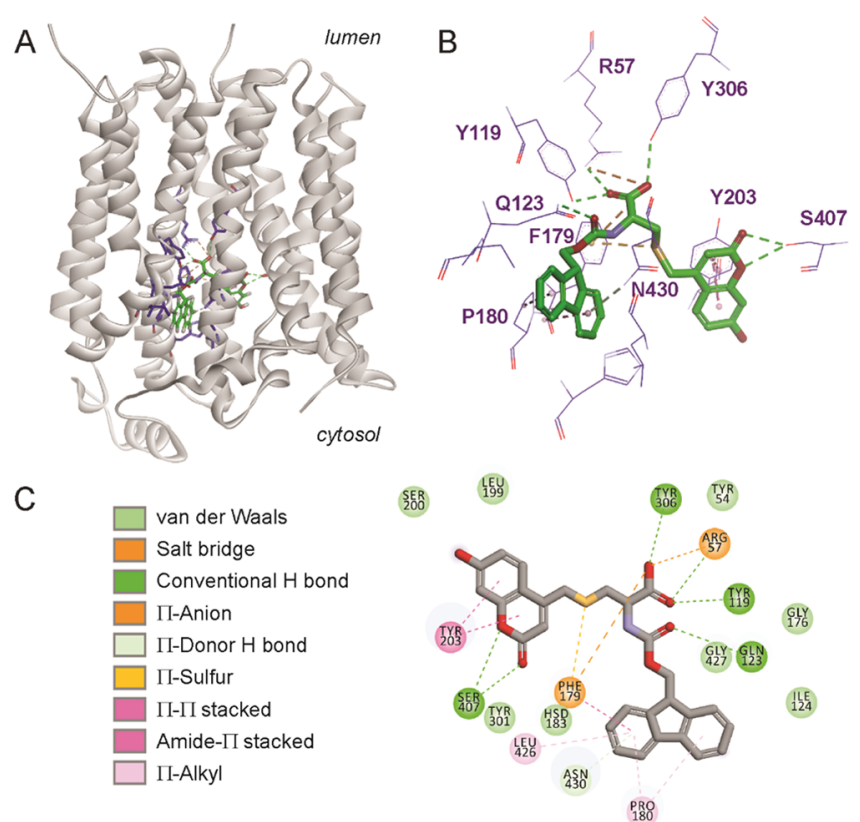

Figure 7. Docking of $\mathbf{4 5}$ to a DgoT-based homology model of human sialin. (A) Side view of the inward-facing homology model with the docked inhibitor (in green). (B, C) Residues involved (purple in (B)) and nature of their interaction with $\mathbf{4 5}$ shown in a $2 \mathrm{D}$ depiction.

for the non-competitive inhibition by this compound. The selected pose was further submitted to a $20 \mathrm{~ns}$ molecular dynamics simulation in a membrane environment to optimize the $3 \mathrm{D}$ structure.

The interaction of $\mathbf{4 5}$ with the inward-facing sialin model is depicted in Figure 7B,C. The carboxylic group of sialic acids and sialin inhibitors, a feature shared with all substrates of SLC17 transporters, is bound to a conserved arginine (R57 in sialin) and two tyrosines (Y119 and Y306). Similar interactions of D-galactonate with this conserved arginine (R47) and two other tyrosines (Y44 and Y79) are essential for substrate recognition and selectivity in DgoT. $^{51}$ 


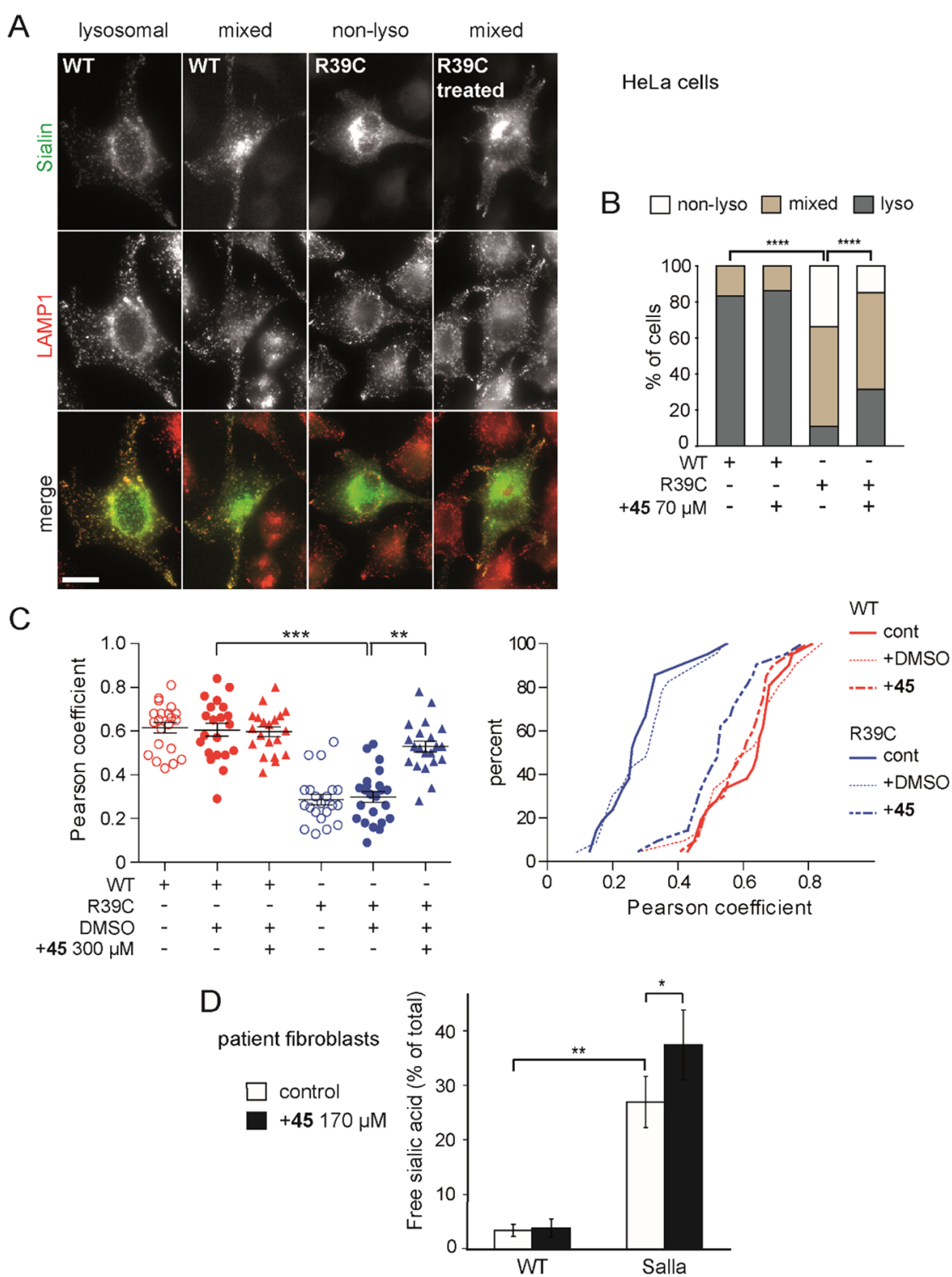

Figure 8. Effect of compound 45 on the R39C mutant. (A, B) Wild-type or R39C human sialin tagged with EGFP was transiently expressed in HeLa cells by electroporation in the presence or absence of $45(70 \mu \mathrm{M})$. After two days, cells were fixed and analyzed under fluorescence microscopy using LAMP1 immunostaining (red) to detect late endosomes and lysosomes. Sialin localization was categorized as illustrated in (A) in a blind manner. The graph (B) synthesizes the outcome of three independent experiments (162 to 184 cells per condition; $\chi^{2}$ test: $* * *, p<0.001$; $* * * *, p<0.0001)$. (C) In independent experiments, colocalization was quantitated using scatter plots of the sialin and LAMP1 pixel intensities. The graphs show the distribution of Pearson's correlation coefficient across 20 to 25 cells per condition in a representative example of three independent experiments (Kruskal-Wallis one-way ANOVA with post hoc Dunn's test: $* *, p<0.01 ; * *, p<0.001$ ). (D) Skin fibroblasts from a healthy subject (WT) and a compound-heterozygote (p.Arg39Cys/Leu336Trpfs) Salla patient were cultured for 2 days with or without 45 (170 $\mu \mathrm{M})$ and assayed for free sialic acid level by micro-LC/ESI MRM-MS3 (means \pm SEM of four independent experiments; $t$-test: $*=p<0.05 ; * *=$ $p<0.01)$.

Two hydrophobic moieties of $\mathbf{4 5}$ are expected to block the alternating-access transition of the transporter: an Fmoc group on the amino function of the cysteine core and a coumarinyl group on the side chain of that amino acid. On one side, the $9 \mathrm{H}$-fluorene part of the Fmoc group makes hydrophobic interactions with F179, P180, and L426 and several van der Waals contacts with I124, H183, G427, and N430. The carbonyl of the Fmoc group establishes a hydrogen bond with Q123. On the other side of the ligand, the coumarinyl group forms hydrogen bonds with S407, a $\Pi$ stacking with Y203, and van der Waals contacts with L199 and Y301. In between, F179 contacts with the sulfur atom and carboxylate (Figure 7B,C). In MFS transporters, helical discontinuities in specific TMs act as molecular hinges for the rotation of the $\mathrm{N}$ and $\mathrm{C}$ domains during alternating-access transitions. ${ }^{49}$ In DgoT, TM4 has a kink at P135 (P180 in sialin) and TM10 is continuous in the outward-facing conformation whereas TM4 is continuous and TM10 has a kink in the inward-facing conformation. ${ }^{51}$ The tight interactions of $\mathbf{4 5}$ with residues close to these kinks (Y179, P180 in TM4; S407 in TM10) in the sialin model should block alternating-access movements, providing an explanation for its inhibition of Neu5Ac transport.

Compound 45 Partially Rescues the Sialin R39C Mutant. The R39C mutation causing Salla disease induces a trafficking defect of $\operatorname{sialin}^{6,27}$ possibly due to its destabilization and recognition by chaperones of the protein quality control 
system. We reasoned that $\mathbf{4 5}$ binding to the cytosolic side of sialin might stabilize nascent R39C polypeptides in the endoplasmic reticulum and rescue their delivery to lysosomes.

$45(12 \mu \mathrm{M})$ efficiently inhibited the residual transport activity of sialin R39C in our whole-cell assay (Figure S4), showing that 45 binding is not impaired by the pathogenic mutation. We thus transiently expressed wild-type (WT) or R39C human sialin fused to EGFP (with an intact sorting motif) in HeLa cells in the absence or presence of $45(70 \mu \mathrm{M})$ and examined their intracellular distribution by fluorescence microscopy. As this distribution varies across cells in a given condition (Figure 8A), sialin was compared to a lysosomal marker (LAMP1) and the dual staining in individual cells was classified into three categories: lysosomal $(\geq 70 \%$ overlap between sialin and LAMP1 puncta), non-lysosomal ( $\leq 30 \%$ overlap), and mixed. In agreement with earlier studies, the lysosomal category predominated in untreated cells expressing WT sialin (83\%) whereas this category dropped to $11 \%$ for the R39C mutant with a predominance of the mixed (55\%) and non-lysosomal (34\%) categories. However, when sialin R39C was expressed in the presence of $45(72 \mu \mathrm{M})$, the lysosomal category increased to $32 \%$ at the expense of the non-lysosomal category (15\%), while this treatment did not alter the distribution of WT sialin (Figure 8B). Similar results were observed when sialin was expressed by lipofection instead of electroporation (Figure S4). 45 thus partially rescues the trafficking defect of the R39C mutant. To confirm this effect, we repeated these experiments and quantitated the colocalization between EGFP-sialin and LAMP1 using scatter plots and Pearson's correlation coefficient analysis of the pixel fluorescence intensities. This analysis showed a much lower level of sialin R39C/LAMP1 colocalization relative to the wildtype. When sialin R39C-expressing cells were treated with a high dose $(300 \mu \mathrm{M})$ of 45 , colocalization was rescued to a level close to that of the wild-type (Figure 8C).

Next, we tested whether this increased delivery of sialin $\mathrm{R} 39 \mathrm{C}$ to lysosomes could decrease sialic acid storage in patient cells. We used Salla fibroblasts from a compound-heterozygote patient (R39C and L336W + frameshift alleles) because these cells accumulate sialic acid to higher levels than homozygous R39C cells. ${ }^{54}$ Compound-heterozygote Salla fibroblasts and control fibroblasts were thus treated or not with 45 (30 to 170 $\mu \mathrm{M}$ ) for 2 days, and their level of free sialic acid was assayed by mass spectrometry. Salla fibroblasts cultured in standard medium accumulated free sialic acid by $\sim 8$-fold as compared to control fibroblasts. The $\mathbf{4 5}$ treatment did not reduce but instead slightly increased this accumulation (Figure 8C), probably reflecting an inhibition of sialin $\mathrm{R} 39 \mathrm{C}$ by 45 at the lysosomal membrane. To circumvent this effect, we used a pulse-chase protocol in which the drug was applied for 2 days to correct the trafficking defect followed by a $6 \mathrm{~h}$ chase in drugfree medium to remove lysosomal inhibition. However, this treatment did not reverse sialic acid storage (data not shown).

\section{DISCUSSION}

In this study, we exploited our previous virtual screening of human sialin ${ }^{33}$ and report chemical substitutions of validated virtual hits. This led to the identification of a novel ligand scaffold unrelated to sugar substrates, which is characterized by an amino acid backbone, a free carboxylate, a $N$-linked aromatic or heteroaromatic substituent, and a hydrophobic side chain.
Two ligands with this scaffold, Fmoc-Leu-OH 13 and 45, were characterized in more detail. They inhibited Neu5Ac transport with $\mathrm{IC}_{50}$ of 23 and $2.4 \mu \mathrm{M}$ as compared to an $\mathrm{IC}_{50}$ of $\sim 1 \mathrm{mM}$ for Neu5Ac. Neither compound was translocated by sialin (Figures S1 and S2), and somewhat surprisingly, both inhibited Neu5Ac transport in a non-competitive, rather than a competitive, manner (Figure 5), notwithstanding the substratebinding pocket focus of our virtual screening. ${ }^{33}$ In contrast, another sialin inhibitor identified in this screen, the endothelinA receptor antagonist FR139317, inhibited Neu5Ac transport in a competitive manner. ${ }^{33}$

This apparent paradox could be explained in a model where the new compounds permeate biological membranes and bind to sialin in a cytosol-facing (inward-facing) rather than lumenfacing (outward-facing) conformation. The protonation of the carboxylate group at $\mathrm{pH} 5.0$ and the high partition coefficient of these compounds facilitate their passive diffusion into the cells in our assay of sialin transport activity. As structural transition equilibriums are slower than ligand binding equilibriums, this mechanism should trap sialin in an inwardfacing state (Figure 5C) and prevent extracellular Neu5Ac binding to the lumen-facing state, thus decreasing the transport capacity. A similar non-competitive inhibition of a transporter by ligands of the substrate pocket has been reported for the interaction between the glucose transporter GLUT1 and cytochalasin $\mathrm{B}$ or forskolin. ${ }^{55}$ An analogous mechanism also occurs in enzymes undergoing a conformational change when inhibitors selectively bind to the product-favoring conformation. ${ }^{56}$ Selective or predominant binding of Fmoc-Leu-OH and 45 to an inward-facing state of sialin may thus account for their non-competitive inhibition.

We provide two pieces of evidence in support of this hypothesis. First, inhibition of sialin by Fmoc-Leu-OH and $\mathbf{4 5}$ in our whole-cell assay persisted after a $15 \mathrm{~min}$ wash (Figure $6)$, in agreement with an action in the cytosolic rather than extracellular compartment. Second, we built a more accurate inward-facing homology model of human sialin based on the recent crystallographic structures of the $\mathrm{H}^{+} / \mathrm{D}$-galactonate symporter DgoT. ${ }^{51}$ Molecular docking of $\mathbf{4 5}$ to this model showed that it binds well to the substrate pocket of the inwardfacing state, in agreement with our model. However, other potential mechanisms for the non-competitive inhibition such as the existence of another 45-binding site cannot be excluded. Further studies are needed to distinguish between these possibilities.

The best docked pose of $\mathbf{4 5}$ showed several interesting features, including an interaction of its carboxylate group with a conserved arginine in TM1 (R57 in human sialin) that is required for D-galactonate binding in DgoT $^{51}{ }^{51} 45$ may thus share common interactions with the anionic substrates of sialin. Another notable feature is the interaction of $\mathbf{4 5}$ with residues in TM4 and TM10 that act as hinge regions for alternating-access structural transitions in DgoT. ${ }^{51} 45$ binding to human sialin should thus impair its structural transitions, explaining why this compound blocks Neu5Ac transport.

The identification of $\mathbf{4 5}$ as a cell-permeant ligand of the "active" site (sialic acid pocket) of sialin prompted us to test whether it might act as a pharmacological chaperone proof-ofprinciple for the treatment of Salla disease. Pharmacological chaperones are selective ligands that bind to and stabilize misfolded mutant proteins to rescue their retention by the protein quality control system. ${ }^{57,58}$ This approach is a promising option for Salla disease as this condition is almost 
exclusively caused by a single mutation, R39C, ${ }^{18}$ which partially preserves the lysosomal targeting and the transport activity of sialin. 6,7 We thus applied 45 to sialin R39Ctransfected cells and Salla patient fibroblasts to test its potential benefits. Interestingly, this treatment partially rescued the trafficking defect of sialin R39C. However, it did not rescue sialic acid storage in patient fibroblasts, presumably because the rescue of the trafficking defect remained insufficient and/or this effect was masked by the inhibition of sialin R39C at the lysosomal membrane. The slight increase of sialic acid storage upon 45 treatment supports the latter hypothesis. In this respect, the lack of competition between Neu5Ac accumulated in the lumen of patient lysosomes and 45 binding at the cytosolic face of sialin would be a disadvantage for therapeutic applications.

In summary, our study identifies a new class of cell-permeant inhibitors with a micromolar affinity for sialin, providing valuable tools to study the diverse transport activities of sialin and their physiological roles. These tools may also help mechanistic and structural studies of sialin. They may also be used to prevent Neu5Gc incorporation into therapeutic glycoproteins produced by cell culture. In the case of Salla disease, however, further studies are needed to explore the potential of pharmacological chaperone therapy.

\section{EXPERIMENTAL SECTION}

General Chemistry Information. All the amino acids belong to the $\mathrm{L}$-series unless specified otherwise. Amino acid derivatives are designated according to the three-letter code and the recommendations from the IUPAC-IUB Commission on Biochemical Nomenclature. Fmoc-Lys( $\mathrm{Cbz})-\mathrm{OH} 3$, Fmoc-Leu-OH 13, Fmoc-Asp $(t \mathrm{Bu})-\mathrm{OH}$ 14, Fmoc-Cys $(t \mathrm{Bu})-\mathrm{OH} 15$, Fmoc- $\mathrm{Tyr}(t \mathrm{Bu})-\mathrm{OH} 17$, Fmoc-Phe-OH 18, Fmoc-Ile-OH 19, Fmoc-Cys(pMeOBzl)-OH 20, Fmoc-Thr $(t \mathrm{Bu})$ $\mathrm{OH} 21$, and Fmoc-Pro-OH 23 were purchased from Novabiochem and used for biological test. $\mathrm{Glu}(\mathrm{OMe})-\mathrm{OH}$, DL-Leu-OH, FmocCys(Trt)-OH, Cys(Bzl)-OH, Fmoc-Lys(Boc)-OH, and HCl-Lys(Cbz)-OMe were purchased from Novabiochem and functionalized. The other reagents were purchased from Aldrich or Acros. Prior to use, tetrahydrofuran (THF) was distilled from sodium benzophenone and dichloromethane $\left(\mathrm{CH}_{2} \mathrm{Cl}_{2}\right)$ from $\mathrm{CaH}_{2}$. All reactions were carried out under an argon atmosphere and monitored by thin-layer chromatography with Merck 60F-254 precoated silica $(0.2 \mathrm{~mm})$ on glass. Flash chromatography was performed with Merck Kieselgel 60 (200-500 mm); the solvent systems were given in $\mathrm{v} / \mathrm{v} .{ }^{1} \mathrm{H}$ NMR $(500 \mathrm{MHz})$ and ${ }^{13} \mathrm{C}$ NMR $(126 \mathrm{MHz})$ spectra were recorded on a Bruker AVANCEII-500 spectrometer. Chemical shifts $(\delta)$ are reported in parts per million. Multiplicity was given using the following abbreviations: s (singlet), brs (broad singlet), d (doublet), $\mathrm{dd}$ (doublet of doublets), $\mathrm{t}$ (triplet), $\mathrm{q}$ (quadruplet), and $\mathrm{m}$ (multiplet). During acquisition, the spectral window covers a proton chemical shift range from -1 to $+12 \mathrm{ppm}$ or from -5 to $+20 \mathrm{ppm}$. ${ }^{13} \mathrm{C}$ chemical attributions were assigned using ${ }^{1} \mathrm{H}$-decoupled spectra. For clarity, in some case, Greek letters are used as locants for NMR attribution of the side chain of the amino acid, while the heterocycle moiety is numbered according to the IUPAC nomenclature. Melting points were determined with a Büchi 530 apparatus and are uncorrected. Mass spectra (MS) were recorded on a Thermo Finnigan LCD Advantage spectrometer and HRMS on an Exactive (Thermo Scientific) spectrometer with positive $\left(\mathrm{ESI}^{+}\right)$or negative $\left(\mathrm{ESI}^{-}\right)$electrospray ionization. HPLC analyses were carried out on a Prominence Shimadzu instrument with an LC20A pump, C18 column $(250 \mathrm{~mm} \times 4.6 \mathrm{~mm}, 5 \mu \mathrm{m})$, flow: $1 \mathrm{~mL} / \mathrm{min}$; eluted peaks were detected by a PDA detector (SPD-M20A), and retention times are reported in minutes. The dead volume is approximately $200 \mu \mathrm{L}$. Products were eluted with method $\mathrm{A}-1$ using solvent $\mathrm{A}\left(\mathrm{KH}_{2} \mathrm{PO} 4\right.$ buffer, $50 \mathrm{mM}, \mathrm{pH} 5.5)$ and solvent $\mathrm{B}\left(\mathrm{CH}_{3} \mathrm{CN}\right)$ : $0 \% \mathrm{~B}$ for $10 \mathrm{~min}$, a linear increase from 0 to $50 \% \mathrm{~B}$ between 10 and $25 \mathrm{~min}$, or with method A-2 using solvent $\mathrm{A}\left(\mathrm{KH}_{2} \mathrm{PO}_{4}\right.$ buffer, $50 \mathrm{mM}$, pH 5.5) and solvent $\mathrm{B}\left(\mathrm{CH}_{3} \mathrm{CN}\right): 0 \% \mathrm{~B}$ for $5 \mathrm{~min}$, a linear increase from 0 to $50 \%$ $\mathrm{B}$ between 5 and $20 \mathrm{~min}$. HPLC-MS analyses were performed on a Surveyor HPLC system coupled to a LCQ Advantage Thermo Finnigan LCQ Advantage Instrument. HPLC was equipped with a Gemini C18 column $(100 \mathrm{~mm} \times 2.1 \mathrm{~mm}, 3 \mu \mathrm{m})$, flow: $220 \mu \mathrm{L} / \mathrm{min}$. The dead volume was approximately $800 \mu \mathrm{L}$. Products were eluted with method $\mathrm{B}$ using solvent $\mathrm{A}\left(\mathrm{H}_{2} \mathrm{O} / 0.1 \% \mathrm{HCO}_{2} \mathrm{H}\right)$ and solvent $\mathrm{B}$ $(\mathrm{MeOH}): 40 \% \mathrm{~B}$ for $1 \mathrm{~min}$, a linear increase from 40 to $100 \% \mathrm{~B}$ between 1 and $9 \mathrm{~min}, 100 \% \mathrm{~B}$ from 10 to $13 \mathrm{~min}$, and with method $\mathrm{C}$ using solvent $\mathrm{A}\left(\mathrm{H}_{2} \mathrm{O} / 0.1 \% \mathrm{HCO}_{2} \mathrm{H}\right)$ and solvent $\mathrm{B}\left(\mathrm{CH}_{3} \mathrm{CN} / 0.1 \%\right.$ $\left.\mathrm{HCO}_{2} \mathrm{H}\right): 40 \%$ B for 1 min, a linear increase from 40 to $100 \%$ B between 1 and $6 \mathrm{~min}, 100 \% \mathrm{~B}$ from 7 to $13 \mathrm{~min}$. The purity of the tested compounds was established by analytical HPLC-MS and HPLC and was at least 95\%. Spectroscopic $\left({ }^{1} \mathrm{H}\right.$ and ${ }^{13} \mathrm{C}$ NMR, MS) and/or analytical data were obtained using chromatographically homogeneous samples. The photophysical properties of the final compounds were obtained by different measurements on the Greiner and Nonchuk 96-well plates using a Tecan spectrofluorometer (Safire). These measurements were carried out in solution in ethanol at $25{ }^{\circ} \mathrm{C}$.

Syntheses. General Procedure $A$ for the Synthesis of Compounds 29, 30, and 31. A $0.5 \mathrm{M}$ solution of $\mathrm{ClTi}(\mathrm{O} i \mathrm{Pr})_{3}(1.5$ equiv) in dry toluene was added to aminophenol (1 equiv) and $\beta$ cetoester ( 1 equiv) derivatives. The reaction mixture was refluxed overnight then cooled to room temperature and diluted with $\mathrm{CH}_{2} \mathrm{Cl}_{2}$ ( $7.5 \mathrm{~mL} / \mathrm{mmol})$. The whole solution was poured into $\mathrm{H}_{2} \mathrm{O}(10 \mathrm{~mL} /$ $\mathrm{mmol}$ ) and stirred for few minutes. The aqueous layer was extracted twice with $\mathrm{CH}_{2} \mathrm{Cl}_{2}(2 \times 30 \mathrm{~mL} / \mathrm{mmol})$. The combined organic layers were dried $\left(\mathrm{Na}_{2} \mathrm{SO}_{4}\right)$, and the solvent was removed under vacuum. The crude product was purified or used directly to another reaction as mentioned in each case.

General Procedure B for the Synthesis of Compounds 37-39, 41, and 44. Heteroaromatic derivatives ( 1 equiv), amino acid derivatives (1-1.2 equiv), and HBTU (1.1-1.2 equiv) were suspended in $\mathrm{CH}_{2} \mathrm{Cl}_{2}(0.1 \mathrm{M})$ then DIEA (4-6 equiv) was added dropwise at $0{ }^{\circ} \mathrm{C}$, and the reaction mixture was stirred for $2 \mathrm{~h}$ at room temperature. The solution was diluted with $\mathrm{CH}_{2} \mathrm{Cl}_{2}(50 \mathrm{~mL} / \mathrm{mmol})$ and washed three times with aqueous $\mathrm{HCl}$ solution $(0.1 \mathrm{M}, 20 \mathrm{~mL}$ / $\mathrm{mmol})$. Aqueous layers were extracted twice with $\mathrm{CH}_{2} \mathrm{Cl}_{2}(50 \mathrm{~mL} /$ $\mathrm{mmol})$ then the organic layers were pooled, dried $\left(\mathrm{Na}_{2} \mathrm{SO}_{4}\right)$, filtered, and evaporated. The mixture was treated with aqueous $\mathrm{LiOH}$ solution $(0.5 \mathrm{M}, 1.2$ equiv)/THF $(1 / 1)$ and stirred for $2 \mathrm{~h}$ at room temperature. The solution was evaporated and diluted with $\mathrm{H}_{2} \mathrm{O}$ then acidified to $\mathrm{pH} 2$ with $\mathrm{HCl}(1 \mathrm{M})$. The precipitate was filtered and, when necessary, purified by column chromatography on silica gel $\left(\mathrm{CH}_{2} \mathrm{Cl}_{2} / \mathrm{MeOH} / \mathrm{AcOH}: 95 / 5 / 0.1\right.$ to $\left.85 / 15 / 1\right)$.

4-Carboxymethyl-7-dimethylamino-coumarin (29). General procedure A was followed using $\mathrm{ClTi}(\mathrm{O} i \mathrm{Pr})_{3}(1.791 \mathrm{~mL}, 7.5 \mathrm{mmol})$ in toluene $(12 \mathrm{~mL})$, 3-dimethylaminophenol $(0.685 \mathrm{~g}, 5 \mathrm{mmol})$, and dimethyl 3-oxoglutarate $(1.791 \mathrm{~mL}, 5 \mathrm{mmol})$. The crude product was dissolved in $\mathrm{MeOH}(12.5 \mathrm{~mL})$ and aqueous $\mathrm{NaOH}$ solution $(1 \mathrm{M}$, $12.5 \mathrm{~mL}$ ) and stirred overnight at room temperature. The solution was acidified to $\mathrm{pH} 5$ with aqueous $\mathrm{HCl}$ solution $(2 \mathrm{M})$, and the resulting precipitate was recovered by filtration, washed with $\mathrm{HCl}(0.1$ $\mathrm{M})$, and dried under vacuum. Compound $29(0.487 \mathrm{~g})$ was obtained as a green-yellow powder in a $40 \%$ yield. ${ }^{1} \mathrm{H}$ NMR $(500 \mathrm{MHz}$, $\left.\left(\mathrm{CD}_{3}\right)_{2} \mathrm{SO}\right): \delta 7.47(\mathrm{~d}, J=9.0 \mathrm{~Hz}, 1 \mathrm{H}, \mathrm{H}-5), 6.72(\mathrm{dd}, J=9.0 \mathrm{~Hz}, J=$ $2.5 \mathrm{~Hz}, 1 \mathrm{H}, \mathrm{H}-6), 6.56$ (d, $J=2.5 \mathrm{~Hz}, 1 \mathrm{H}, \mathrm{H}-8), 6.05$ (s, $1 \mathrm{H}, \mathrm{H}-3)$, $3.77\left(\mathrm{~s}, 2 \mathrm{H}, \mathrm{CH}_{2}\right), 3.01\left(\mathrm{~s}, 6 \mathrm{H}, \mathrm{CH}_{3}\right) ;{ }^{13} \mathrm{C}$ NMR $(126 \mathrm{MHz}$, $\left.\left(\mathrm{CD}_{3}\right)_{2} \mathrm{SO}\right): \delta 170.7\left(\mathrm{CO}_{2} \mathrm{H}\right), 160.6(\mathrm{C}=\mathrm{O}), 155.4(\mathrm{Cq}-\mathrm{O}), 152.8$ (Cq-Ar), $150.2(\mathrm{Cq}-\mathrm{N}), 126.0,109.6,109.1$ (CH-Ar), 108.0 (Cq-Ar), 97.5 (CH-Ar), $40.1\left(2 \times \mathrm{NCH}_{3}\right), 37.2\left(\mathrm{CH}_{2}\right)$; $\mathrm{MS}:\left(\mathrm{ESI}^{+}\right), m / z(\%)$ : $[\mathrm{M}+\mathrm{H}]^{+}=248.3(100 \%) ;[2 \mathrm{M}+\mathrm{Na}]^{+}=517.0(80 \%) ; \lambda_{\mathrm{abs}}^{\max }=373$ $\mathrm{nm}, \lambda_{\mathrm{em}}^{\max }=443 \mathrm{~nm}, \varepsilon\left(\lambda_{\max }\right)=23,300 \mathrm{M}^{-1} \mathrm{~cm}^{-1}, \Phi=0.677$.

4-Carboxymethyl-7-diethylamino-coumarin (30). General procedure A was followed using $\mathrm{ClTi}(\mathrm{OiPr})_{3}(3.582 \mathrm{~mL}, 15 \mathrm{mmol})$ in toluene $(25 \mathrm{~mL}), 3$-diethylaminophenol $(1.652 \mathrm{~g}, 10 \mathrm{mmol})$, and dimethyl 3-oxoglutarate $(1.470 \mathrm{~mL}, 10 \mathrm{mmol})$. The crude product was dissolved in $\mathrm{MeOH}(25 \mathrm{~mL})$ and aqueous $\mathrm{NaOH}$ solution $(1 \mathrm{M}$, 
$25 \mathrm{~mL}$ ) then stirred overnight at room temperature. The solution was acidified to $\mathrm{pH} 5$ with aqueous $\mathrm{HCl}$ solution $(2 \mathrm{M})$, and the resulting precipitate was recovered by filtration, washed with $\mathrm{HCl}(0.1 \mathrm{M})$, and dried under vacuum. Compound $30(0.947 \mathrm{~g})$ was obtained as a green powder in a $35 \%$ yield. ${ }^{1} \mathrm{H}$ NMR $\left(500 \mathrm{MHz},\left(\mathrm{CD}_{3}\right)_{2} \mathrm{SO}\right): \delta 7.44(\mathrm{~d}, J$ $=9.0 \mathrm{~Hz}, 1 \mathrm{H}, \mathrm{H}-5), 6.69(\mathrm{dd}, J=9.0 \mathrm{~Hz}, J=2.5 \mathrm{~Hz}, 1 \mathrm{H}, \mathrm{H}-6), 6.51$ (d, $J=2.5 \mathrm{~Hz}, 1 \mathrm{H}, \mathrm{H}-8), 5.99$ (s, $1 \mathrm{H}, \mathrm{H}-3), 3.75\left(\mathrm{~s}, 2 \mathrm{H}, \mathrm{CH}_{2} \mathrm{CO}_{2} \mathrm{H}\right)$, $3.41\left(\mathrm{q}, \mathrm{J}=7.0 \mathrm{~Hz}, 4 \mathrm{H}, \mathrm{NCH}_{2}\right), 1.11\left(\mathrm{t}, J=7.0 \mathrm{~Hz}, 6 \mathrm{H}, \mathrm{CH}_{3}\right) ;{ }^{13} \mathrm{C}$ NMR $\left(126 \mathrm{MHz},\left(\mathrm{CD}_{3}\right)_{2} \mathrm{SO}\right): \delta 170.7\left(\mathrm{CO}_{2} \mathrm{H}\right), 160.7(\mathrm{C}=\mathrm{O})$, 155.8 (Cq-O), 150.4 (Cq-Ar), $150.1(\mathrm{Cq}-\mathrm{N}), 126.3,109.1,108.7$ (CH-Ar), 107.6 (Cq-Ar), 96.8 (CH-Ar), $44.0\left(2 \times \mathrm{NCH}_{2}\right), 37.2$ $\left(\mathrm{CH}_{2} \mathrm{CO}_{2} \mathrm{H}\right), 12.3\left(2 \times \mathrm{CH}_{3}\right)$; $\mathrm{MS}:\left(\mathrm{ESI}^{+}\right), \mathrm{m} / z(\%):[\mathrm{M}+\mathrm{H}]^{+}=$ $276.3(100 \%) ;[2 \mathrm{M}+\mathrm{Na}]^{+}=573.0(85 \%) ;[2 \mathrm{M}+\mathrm{H}]^{+}=550.9$ (70\%).

2-(11-Oxo-2,3,6,7-tetrahydro-1H,5H,11H-pyrano[2,3-f]pyrido[3,2,1-ij]quinolin-9-yl)acetic acid (31). From ClTi( $\mathrm{OiPr})_{3}(2.262$ $\mathrm{mL}, 6.75 \mathrm{mmol})$ in toluene $(9 \mathrm{~mL}), 8$-hydroxyjulodin $(0.851 \mathrm{~g}, 4.5$ $\mathrm{mmol})$, and dimethyl 3-oxoglutarate $(681 \mu \mathrm{L}, 4.5 \mathrm{mmol})$, compound 31 as methyl ester was obtained according to general procedure $\mathrm{A}$ and used without further purification in the next step. ${ }^{1} \mathrm{H}$ NMR (500 $\mathrm{MHz}_{\mathrm{CDCl}}$ ): $\delta 6.99$ (s, 1H, H-8), $5.98(\mathrm{~s}, 1 \mathrm{H}, \mathrm{H}-10), 3.70(\mathrm{~s}, 3 \mathrm{H}$, $\left.\mathrm{CH}_{3}\right), 3.61\left(\mathrm{~s}, 2 \mathrm{H}, \mathrm{CH}_{2} \mathrm{CO}_{2} \mathrm{CH}_{3}\right), 3.26\left(\mathrm{q}, J=6.0 \mathrm{~Hz}, 4 \mathrm{H}, \mathrm{CH}_{2}-\mathrm{N}\right)$, $2.89\left(\mathrm{t}, J=6.5 \mathrm{~Hz}, 2 \mathrm{H}, \mathrm{CH}_{2}-\mathrm{Ph}\right), 2.79\left(\mathrm{t}, J=6.5 \mathrm{~Hz}, 2 \mathrm{H}, \mathrm{CH}_{2}-\mathrm{Ph}\right)$, $1.98\left(\mathrm{~m}, 4 \mathrm{H}, \mathrm{CH}_{2}-\mathrm{CH}_{2}-\mathrm{CH}_{2}\right)$. Methyl ester 31 was then dissolved in $\mathrm{MeOH}(15 \mathrm{~mL})$ and aqueous $\mathrm{NaOH}$ solution $(1 \mathrm{M}, 15 \mathrm{~mL})$, and the mixture was stirred overnight at room temperature. The $\mathrm{pH}$ was adjusted to 2 with aqueous $\mathrm{HCl}$ solution $(1 \mathrm{M})$, and the resulting precipitate was recovered by filtration and washed with aqueous $\mathrm{HCl}$ solution $(0.1 \mathrm{M}, 30 \mathrm{~mL})$. Compound $31(0.890 \mathrm{~g})$ was obtained as a yellow powder in a $66 \%$ yield. mp: $186-187^{\circ} \mathrm{C}$; ${ }^{1} \mathrm{H}$ NMR $(500 \mathrm{MHz}$, $\left.\left(\mathrm{CD}_{3}\right)_{2} \mathrm{SO}\right): \delta 12.67$ (brs, $\left.1 \mathrm{H}, \mathrm{CO}_{2} \mathrm{H}\right), 7.05(\mathrm{~s}, 1 \mathrm{H}, \mathrm{H}-8), 5.94(\mathrm{~s}, 1 \mathrm{H}$, $\mathrm{H}-10), 3.71\left(\mathrm{~s}, 2 \mathrm{H}, \mathrm{CH}_{2} \mathrm{CO}_{2} \mathrm{H}\right), 3.24\left(\mathrm{~m}, 4 \mathrm{H}, \mathrm{CH}_{2}-\mathrm{N}\right), 2.71(\mathrm{~m}, 4 \mathrm{H}$, $\left.\mathrm{CH}_{2}-\mathrm{Ph}\right), 1.88\left(\mathrm{~m}, 4 \mathrm{H}, \mathrm{CH}_{2}-\mathrm{CH}_{2}-\mathrm{CH}_{2}\right) ;{ }^{13} \mathrm{C}$ NMR $(126 \mathrm{MHz}$, $\left.\left(\mathrm{CD}_{3}\right)_{2} \mathrm{SO}\right): \delta 170.8\left(\mathrm{CO}_{2} \mathrm{H}\right), 160.7(\mathrm{C}=\mathrm{O}), 150.7,150.1,145.5$ (Cq-Ar), 122.0 (CH-Ar), 117.7 (Cq-Ar), 108.3 (CH-Ar), 107.4, 105.6 (Cq-Ar), 49.2, $48.6\left(\mathrm{CH}_{2}-\mathrm{N}\right), 37.2\left(\mathrm{CH}_{2} \mathrm{CO}_{2} \mathrm{H}\right), 27.0,20.9$, 20.0, $19.9\left(\mathrm{CH}_{2}\right)$; MS: $\left(\mathrm{ESI}^{+}\right), m / z(\%):[\mathrm{M}+\mathrm{H}]^{+}=300.1(80 \%)$; $[2 \mathrm{M}+\mathrm{Na}]^{+}=621.1(100 \%)$.

3-(3,6-Dihydroxy-xanthen-9-ylidene)propanoic Acid (32). A stirred mixture of succinic anhydride $(2.50 \mathrm{~g}, 25 \mathrm{mmol}, 0.5$ equiv) and resorcinol ( $2.75 \mathrm{~g}, 25 \mathrm{mmol}, 1$ equiv) in aqueous $\mathrm{H}_{2} \mathrm{SO}_{4}$ solution $(70 \%, 30 \mathrm{~mL})$ was heated to $140{ }^{\circ} \mathrm{C}$ for $4 \mathrm{~h}$. The reaction mixture was then cooled to room temperature and poured into $\mathrm{H}_{2} \mathrm{O}(500 \mathrm{~mL})$. The stirred solution was alkalinized to $\mathrm{pH} 12$ with aqueous $\mathrm{NaOH}$ solution $(50 \%)$, while the temperature was kept at $0{ }^{\circ} \mathrm{C}$. Acetic acid was added to the solution until $\mathrm{pH} 4$, and the resulting brown precipitate was filtered. The filtrate was washed with $\mathrm{H}_{2} \mathrm{O}(3 \times 25$ $\mathrm{mL})$ and acetone $(15 \mathrm{~mL})$ and dried under reduced pressure to give pure compound $32(3.28 \mathrm{~g})$ as an orange solid in a $92 \%$ yield from resorcinol. ${ }^{1} \mathrm{H}$ NMR $\left(500 \mathrm{MHz},\left(\mathrm{CD}_{3}\right)_{2} \mathrm{SO}\right): \delta 7.51(\mathrm{~d}, 1 \mathrm{H}, J=8.5$ $\mathrm{Hz}, \mathrm{H}-\mathrm{Ar}$ ), 7.41 (d, $1 \mathrm{H}, J=8.5 \mathrm{~Hz}, \mathrm{H}-\mathrm{Ar}), 6.65-6.47$ (m, 4H, H-Ar), $5.87(\mathrm{t}, 1 \mathrm{H}, J=7.0 \mathrm{~Hz}, \mathrm{C}=\mathrm{CH}), 3.31\left(\mathrm{~d}, 2 \mathrm{H}, J=7.0 \mathrm{~Hz}, \mathrm{CH}_{2}-\mathrm{CH}\right)$; ${ }^{13} \mathrm{C}$ NMR $\left(126 \mathrm{MHz},\left(\mathrm{CD}_{3}\right)_{2} \mathrm{SO}\right): \delta 173.5\left(\mathrm{CO}_{2} \mathrm{H}\right), 158.2,157.9$ $(\mathrm{Cq}-\mathrm{OH}), 153.0,151.3$ (Cq-Ar), 128.6 (CH-Ar), 125.7 (Cq-Ar), 124.3, 116.1 (CH-Ar), 114.0, 113.1 (Cq-Ar), 112.0 (CH-Ar), 110.8 $(=\mathrm{CH}), 102.6,102.3(\mathrm{CH}-\mathrm{Ar}), 36.3\left(\mathrm{CH}_{2}\right) ; \mathrm{MS}:\left(\mathrm{ESI}^{+}\right), \mathrm{m} / z(\%)$ : $[\mathrm{M}+\mathrm{H}]^{+}=285.1(100 \%) ; \lambda_{\mathrm{abs}}^{\max }=455 \mathrm{~nm}, \lambda_{\mathrm{em}}^{\max }=516 \mathrm{~nm}, \varepsilon\left(\lambda_{\max }\right)=$ $5140 \mathrm{M}^{-1} \mathrm{~cm}^{-1}, \Phi=0.243$.

4-Hydroxymethyl-7-methoxymethoxy-coumarin (33). Compound 27 (0.576 g, $3 \mathrm{mmol}, 1$ equiv) was suspended in $\mathrm{CH}_{2} \mathrm{Cl}_{2}$ at $0{ }^{\circ} \mathrm{C}$. DIEA ( $272 \mu \mathrm{L}, 3.6 \mathrm{mmol}, 1.2$ equiv) and MOM-Cl ( $627 \mu \mathrm{L}, 3.6$ mmol, 1.2 equiv) were added dropwise, and the solution was stirred for $45 \mathrm{~min}$ at $0{ }^{\circ} \mathrm{C}$. After evaporation under reduced pressure, $\mathrm{H}_{2} \mathrm{O}$ $(10 \mathrm{~mL})$ was added to the residue and the resulting precipitate was recovered by filtration and dried under vacuum. Compound 33 $(0.511 \mathrm{~g})$ was obtained as a white solid in a $71 \%$ yield. ${ }^{1} \mathrm{H}$ NMR (500 $\left.\mathrm{MHz},\left(\mathrm{CD}_{3}\right)_{2} \mathrm{SO}\right): \delta 7.63(\mathrm{~d}, J=8.5 \mathrm{~Hz}, 1 \mathrm{H}, \mathrm{H}-5), 7.04(\mathrm{~d}, J=2.5$ $\mathrm{Hz}, 1 \mathrm{H}, \mathrm{H}-8), 7.00(\mathrm{dd}, J=8.5 \mathrm{~Hz}, J=2.5 \mathrm{~Hz}, 1 \mathrm{H}, \mathrm{H}-6), 6.32(\mathrm{~s}, 1 \mathrm{H}$, $\mathrm{H}-3), 5.30\left(\mathrm{~s}, 2 \mathrm{H}, \mathrm{OCH}_{2} \mathrm{O}\right), 4.72\left(\mathrm{~s}, 2 \mathrm{H}, \mathrm{CH}_{2} \mathrm{OH}\right), 3.39(\mathrm{~s}, 3 \mathrm{H}$, $\left.\mathrm{CH}_{3}\right) ;{ }^{13} \mathrm{C}$ NMR $\left(126 \mathrm{MHz},\left(\mathrm{CD}_{3}\right)_{2} \mathrm{SO}\right): \delta 160.3(\mathrm{C}=\mathrm{O}), 159.4$
(Cq-7), 156.4 (Cq-4), 154.4 (Cq-8a), 125.4 (CH-5), 113.1 (CH-6), 111.5 (Cq-4a), 103.2, 103.1 (CH-3, CH-8), $93.9\left(\mathrm{OCH}_{2} \mathrm{O}\right), 59.0$ $\left(\mathrm{CH}_{2} \mathrm{OH}\right), 58.9\left(\mathrm{CH}_{3}\right)$; MS: $\left(\mathrm{ESI}^{+}\right), m / z(\%):[\mathrm{M}+\mathrm{H}]^{+}=237.1$ $(100 \%)$.

7-(Methoxymethoxy)-4-(Fmoc-oxymethyl)-coumarin (34). Fmoc-Cl ( $0.206 \mathrm{~g}, 0.8 \mathrm{mmol}, 1.2$ equiv) was added by portion over $30 \mathrm{~min}$ to a solution of compound $33(0.160 \mathrm{~g}, 0.68 \mathrm{mmol}, 1$ equiv) in dry pyridine $(3 \mathrm{~mL})$. After stirring for $2 \mathrm{~h}$ at room temperature, the reaction mixture was diluted with EtOAc $(20 \mathrm{~mL})$ and washed with brine $(3 \times 20 \mathrm{~mL})$. The organic layer was dried, filtered, and evaporated under vacuum. The residue was purified by silica-gel column chromatography (cyclohexane/EtOAc: $9 / 1$ to $7 / 3$ ). Compound $34(0.108 \mathrm{~g})$ was obtained as a white powder in a $34 \%$ yield. ${ }^{1} \mathrm{H}$ NMR (500 MHz, $\mathrm{CDCl}_{3}$ ): $\delta 7.75$ (d, $\left.J=7.5 \mathrm{~Hz}, 2 \mathrm{H}, \mathrm{H}-\mathrm{Ar}\right), 7.59$ (d, $J=7.5 \mathrm{~Hz}, 2 \mathrm{H}, \mathrm{H}-\mathrm{Ar}), 7.40(\mathrm{~m}, 3 \mathrm{H}, \mathrm{H}-\mathrm{Ar}), 7.31(\mathrm{t}, J=6.5 \mathrm{~Hz}$, $2 \mathrm{H}, \mathrm{H}-\mathrm{Ar}$ ), 7.03 (d, $J=2.5 \mathrm{~Hz}, 1 \mathrm{H}, \mathrm{H}-8$ ), 6.97 (dd, $J=9.0 \mathrm{~Hz}, J=2.5$ $\mathrm{Hz}, 1 \mathrm{H}, \mathrm{H}-6), 6.38(\mathrm{t}, J=1.5 \mathrm{~Hz}, 1 \mathrm{H}, \mathrm{H}-3), 5.29(\mathrm{~d}, J=1.5 \mathrm{~Hz}, 2 \mathrm{H}$, $\mathrm{CH}_{2}$-Coum), $5.22\left(\mathrm{~s}, 2 \mathrm{H}, \mathrm{OCH}_{2} \mathrm{O}\right), 4.48(\mathrm{~d}, J=7.0 \mathrm{~Hz}, 2 \mathrm{H}$, $\left.\mathrm{CH}_{2} \mathrm{CH}\right), 4.26\left(\mathrm{t}, \mathrm{J}=7.0 \mathrm{~Hz}, 1 \mathrm{H}, \mathrm{CH}_{2} \mathrm{CH}\right), 3.47\left(\mathrm{~s}, 3 \mathrm{H}, \mathrm{CH}_{3}\right) ;{ }^{13} \mathrm{C}$ NMR $\left(126 \mathrm{MHz}, \mathrm{CDCl}_{3}\right): \delta 160.7,160.6(\mathrm{C}=\mathrm{O}, \mathrm{Cq}-\mathrm{O}), 155.5$ $\left(\mathrm{OCO}_{2}\right), 154.7$ (Cq-OMOM), 148.4 (Cq-Ar), 143.2, 141.5 ( $2 \times \mathrm{Cq}-$ Ar), 128.2, 127.4, 125.3 ( $2 \times \mathrm{CH}-\mathrm{Ar}), 124.6$ (CH-Ar), $120.3(2 \times$ $\mathrm{CH}-\mathrm{Ar}), 113.8$ (CH-Ar), 111.5 (Cq-Ar), 111.1, 104.5 (CH-Ar), 94.6 $\left(\mathrm{OCH}_{2} \mathrm{O}\right), 70.7\left(\mathrm{CH}_{2} \mathrm{CH}\right), 64.7\left(\mathrm{CH}_{2}-\mathrm{Coum}\right), 56.6\left(\mathrm{CH}_{3}\right), 46.9$ $\left(\mathrm{OCH}_{2} \mathrm{CH}\right)$; MS: $\left(\mathrm{ESI}^{+}\right), m / z(\%):[\mathrm{M}+\mathrm{H}]^{+}=459.3(100 \%)$.

7-Hydroxy-4-(Fmoc-oxymethyl)-coumarin (35). Compound 34 $(0.090 \mathrm{~g}, 0.2 \mathrm{mmol})$ was suspended in $\mathrm{CH}_{2} \mathrm{Cl}_{2}(1.5 \mathrm{~mL})$ at $0{ }^{\circ} \mathrm{C}$, and TFA $(1.5 \mathrm{~mL})$ was added. The solution was stirred $1.5 \mathrm{~h}$ at room temperature. After evaporation of the solvents, the residue was purified by silica gel column chromatography (cyclohexane/EtOAc: $9 / 1$ to $7 / 3)$. Compound $35(0.069 \mathrm{~g})$ was obtained as a white powder in an $83 \%$ yield. ${ }^{1} \mathrm{H}$ NMR $\left(500 \mathrm{MHz},\left(\mathrm{CD}_{3}\right)_{2} \mathrm{SO}\right): \delta 10.63(\mathrm{~s}, 1 \mathrm{H}$, $\mathrm{OH}), 7.89$ (d, $J=7.5 \mathrm{~Hz}, 2 \mathrm{H}, \mathrm{H}-\mathrm{Ar}), 7.66$ (d, $J=7.5 \mathrm{~Hz}, 2 \mathrm{H}, \mathrm{H}-\mathrm{Ar})$, $7.51(\mathrm{~d}, J=8.5 \mathrm{~Hz}, 1 \mathrm{H}, \mathrm{H}-5), 7.41(\mathrm{t}, J=7.5 \mathrm{~Hz}, 2 \mathrm{H}, \mathrm{H}-\mathrm{Ar}), 7.32(\mathrm{t}, J$ $=7.5 \mathrm{~Hz}, 2 \mathrm{H}, \mathrm{H}-\mathrm{Ar}), 6.81(\mathrm{dd}, J=8.5 \mathrm{~Hz}, J=2.5 \mathrm{~Hz}, 1 \mathrm{H}, \mathrm{H}-6), 6.75$ (d, $J=2.5 \mathrm{~Hz}, 1 \mathrm{H}, \mathrm{H}-8), 6.08(\mathrm{~s}, 1 \mathrm{H}, \mathrm{H}-3), 5.33\left(\mathrm{~s}, 2 \mathrm{H}, \mathrm{CH}_{2}\right.$-Coum), $4.61\left(\mathrm{~d}, J=6.0 \mathrm{~Hz}, 2 \mathrm{H}, \mathrm{OCH}_{2} \mathrm{CH}\right), 4.34(\mathrm{t}, J=6.0 \mathrm{~Hz}, 1 \mathrm{H}$, $\left.\mathrm{OCH}_{2} \mathrm{CH}\right) ;{ }^{13} \mathrm{C}$ NMR $\left(126 \mathrm{MHz},\left(\mathrm{CD}_{3}\right)_{2} \mathrm{SO}\right): \delta 161.4,159.9,155.0$ (Cq-O), $153.9\left(\mathrm{OCO}_{2}\right), 149.7$ (Cq-Ar), $143.2(2 \times \mathrm{Cq}-\mathrm{Ar}), 140.8(2$ $\times$ Cq-Ar), 127.7, 127.1 (2 × CH-Ar), 125.9 (CH-Ar), 124.8, $120.2(2$ $\times$ CH-Ar), 113.0 (CH-Ar), 108.9 (Cq-4a), $108.4(\mathrm{CH}-3), 102.4$ $(\mathrm{CH}-8), 69.2\left(\mathrm{OCH}_{2} \mathrm{CH}\right), 64.6\left(\mathrm{CH}_{2}-\mathrm{Coum}\right), 46.3\left(\mathrm{OCH}_{2} \mathrm{CH}\right)$; HPLC-MS (method B): $t_{\mathrm{R}}=14.1 \mathrm{~min} ; \mathrm{MS}:\left(\mathrm{ESI}^{+}\right), \mathrm{m} / z(\%):[\mathrm{M}+$ $\mathrm{H}]^{+}=415.1(100 \%) ;[2 \mathrm{M}+\mathrm{Na}]^{+}=850.9(60 \%) ; \mathrm{HRMS}\left(\mathrm{ESI}^{-}\right)$ calcd for $\left[\mathrm{C}_{25} \mathrm{H}_{18} \mathrm{O}_{6}-\mathrm{H}\right]^{-}:$: 413.1030; found: 413.1040; $\lambda_{\mathrm{abs}}^{\max }=324$ $\mathrm{nm}, \lambda_{\mathrm{em}}^{\max }=399 \mathrm{~nm}, \varepsilon\left(\lambda_{\max }\right)=4760 \mathrm{M}^{-1} \mathrm{~cm}^{-1}, \Phi=0.243$.

$N^{6}$-((Benzyloxy) carbonyl- $N^{2}-(2-$ (7-hydroxy-2-oxo-2H-chromen-4yl)acetyl)-L-lysine (36). 7-Hydroxy-4-carboxymethyl-coumarin (0.220 $\mathrm{g}, 1 \mathrm{mmol}, 1$ equiv), HBTU (0.417 g, $1.1 \mathrm{mmol}, 1.1$ equiv), and HOBt $(0.148 \mathrm{~g}, 1.1 \mathrm{mmol}, 1.1$ equiv) were diluted in anhydrous DMF (3 $\mathrm{mL})$. DIEA ( $380 \mu \mathrm{L}, 2.2 \mathrm{mmol}, 2.2$ equiv) was added dropwise, and the resulting solution was stirred for a few minutes then a solution of $\mathrm{HCl} \cdot \mathrm{Lys}(\mathrm{Cbz})-\mathrm{OMe}(0.331 \mathrm{~g}, 1 \mathrm{mmol}, 1$ equiv) in DMF $(1 \mathrm{~mL})$ was added. The reaction mixture was stirred overnight at room temperature, and DMF was evaporated. The residue was diluted in EtOAc $(50 \mathrm{~mL})$, washed with brine $(3 \times 40 \mathrm{~mL})$, dried $\left(\mathrm{Na}_{2} \mathrm{SO}_{4}\right)$, filtered, and evaporated. The ester compound was diluted with THF $(4 \mathrm{~mL})$ and a solution of aqueous $\mathrm{LiOH}(0.5 \mathrm{M}, 4 \mathrm{~mL})$ and stirred 2 $\mathrm{h}$ at room temperature. After evaporation of THF, the $\mathrm{pH}$ was adjusted to 2 with aqueous $\mathrm{HCl}$ solution $(1 \mathrm{M})$ and extracted with EtOAc $(2 \times 40 \mathrm{~mL})$. Organic layers were dried $\left(\mathrm{Na}_{2} \mathrm{SO}_{4}\right)$, filtered, and evaporated. The residue was purified by column chromatography on silica gel $\left(\mathrm{CH}_{2} \mathrm{Cl}_{2} / \mathrm{MeOH} / \mathrm{AcOH}\right.$ : $\left.85 / 15 / 1\right)$. Compound 36 $(0.090 \mathrm{~g})$ was obtained as a white powder in a $19 \%$ yield. mp: $78-79$ ${ }^{\circ} \mathrm{C} ;{ }^{1} \mathrm{H}$ NMR (500 MHz, CD $\left.3 \mathrm{OD}\right): \delta 7.47$ (d, $J=8.5 \mathrm{~Hz}, 1 \mathrm{H}, \mathrm{H}-\mathrm{Ar}$ ), $7.17(\mathrm{~m}, 5 \mathrm{H}, \mathrm{H}-\mathrm{Ph}), 6.64$ (d, $J=8.5 \mathrm{~Hz}, 1 \mathrm{H}, \mathrm{H}-\mathrm{Ar}), 6.54(\mathrm{~s}, 1 \mathrm{H}, \mathrm{H}-$ $\mathrm{Ar}), 6.06(\mathrm{~s}, 1 \mathrm{H}, \mathrm{H}-\mathrm{Ar}), 4.89\left(\mathrm{~s}, 2 \mathrm{H}, \mathrm{CH}_{2}-\mathrm{Ph}\right), 4.19(\mathrm{~m}, 1 \mathrm{H}, \mathrm{H}-\alpha)$, $3.60\left(\mathrm{~s}, 2 \mathrm{H}, \mathrm{CH}_{2}\right.$-Coum), $2.93(\mathrm{~m}, J=6.5 \mathrm{~Hz}, 2 \mathrm{H}, \mathrm{H}-\varepsilon), 1.70,1.56$ $(2 \mathrm{~m}, 2 \mathrm{H}, \mathrm{H}-\beta), 1.34-1.25(\mathrm{~m}, 4 \mathrm{H}, \mathrm{H}-\gamma, \mathrm{H}-\delta) ;{ }^{13} \mathrm{C}$ NMR $(126 \mathrm{MHz}$, $\left.\mathrm{CD}_{3} \mathrm{OD}\right): \delta 175.2\left(\mathrm{CO}_{2} \mathrm{H}\right), 170.8(\mathrm{CONH}), 163.1,163.0,158.9$ 
(CO-Coum), $156.8\left(\mathrm{NHCO}_{2}\right), 152.6,138.7$ (Cq-Ar), $129.7(2 \times$ CH-Ar), 129.1 (CH-Ar), 128.9 ( $2 \times \mathrm{CH}-\mathrm{Ar}), 127.9,114.4$ (CH-Ar), 113.2 (CH-Ar, Cq-Ar), 103.8 (CH-Ar), $67.3\left(\mathrm{OCH}_{2}-\mathrm{Ph}\right), 66.9\left(\mathrm{CH}_{2}-\right.$ Coum), 54.0 (C- $\alpha$ ), 41.6 (C- $\varepsilon$ ), 32.2 (C- $\beta$ ), 30.6 (C- $\delta$ ), 24.3 (C- $\gamma$ ); HPLC (method A-2): $t_{\mathrm{R}}=13.2$ min; HPLC-MS $(\operatorname{method} \mathrm{B}): t_{\mathrm{R}}=$ 11.8 min; MS: $\left(\mathrm{ESI}^{+}\right), \mathrm{m} / z(\%):[\mathrm{M}+\mathrm{H}]^{+}=483.1(100 \%),[\mathrm{M}-$ $\left.\mathrm{CO}_{2}+\mathrm{H}\right]^{+}=439.4(20 \%)$; MS: $\left(\mathrm{ESI}^{-}\right), m / z(\%):[\mathrm{M}-\mathrm{H}]^{-}=481.3$ $(100 \%),\left[\mathrm{M}-\mathrm{C}_{7} \mathrm{H}_{8} \mathrm{O}-\mathrm{H}\right]^{-}=373.2(50 \%) ; \mathrm{HRMS}\left(\mathrm{ESI}^{-}\right)$calcd for $\left[\mathrm{C}_{25} \mathrm{H}_{26} \mathrm{~N}_{2} \mathrm{O}_{8}-\mathrm{H}\right]^{-}: 481.1616$; found: 481.1619; $\lambda_{\mathrm{abs}}^{\max }=324 \mathrm{~nm}$, $\lambda_{\mathrm{em}}^{\max }=399 \mathrm{~nm}, \varepsilon\left(\lambda_{\max }\right)=9880 \mathrm{M}^{-1} \mathrm{~cm}^{-1}, \Phi=0.0904$.

$\mathrm{N}^{6}$-((Benzyloxy) Carbonyl- $\mathrm{N}^{2}$-(2-(7-(dimethylamino)-2-oxo- $2 \mathrm{H}$ chromen-4-yl)acetyl)-L-Lysine (37). From 7-dimethylamino-4-carboxymethyl-coumarin $29(0.125 \mathrm{~g}, 0.5 \mathrm{mmol}, 1$ equiv), $\mathrm{HCl}$. Lys(Cbz)-OMe (0.165 g, $0.6 \mathrm{mmol}, 1.1$ equiv), HBTU (0.220 g, $0.6 \mathrm{mmol}, 1.1$ equiv), and DIEA (346 $\mu \mathrm{L}, 2.0 \mathrm{mmol}, 4$ equiv), compound $37(0.128 \mathrm{~g})$ was obtained by filtration as a yellow powder in a $50 \%$ yield according to general procedure $\mathrm{B} .{ }^{1} \mathrm{H} \mathrm{NMR}(500 \mathrm{MHz}$, $\left.\left(\mathrm{CD}_{3}\right)_{2} \mathrm{SO}\right): \delta 8.55(\mathrm{~d}, J=7.0 \mathrm{~Hz}, 1 \mathrm{H}, \mathrm{NH}), 7.56(\mathrm{~d}, J=9.0 \mathrm{~Hz}, 1 \mathrm{H}$, $\mathrm{H}-5), 7.30(\mathrm{~m}, 6 \mathrm{H}, \mathrm{H}-\mathrm{Ph}, \mathrm{NH}), 6.66(\mathrm{~d}, J=9.0 \mathrm{~Hz}, 1 \mathrm{H}, \mathrm{H}-6), 6.54(\mathrm{~s}$, $1 \mathrm{H}, \mathrm{H}-8), 6.04(\mathrm{~s}, 1 \mathrm{H}, \mathrm{H}-3), 5.00\left(\mathrm{~s}, 2 \mathrm{H}, \mathrm{CH}_{2}-\mathrm{Ph}\right), 4.16(\mathrm{~m}, 1 \mathrm{H}, \mathrm{H}-$ $\alpha), 3.67\left(\mathrm{~s}, 2 \mathrm{H}, \mathrm{CH}_{2}-\mathrm{Coum}\right), 3.00\left(\mathrm{~m}, 8 \mathrm{H}, \mathrm{H}-\varepsilon, \mathrm{CH}_{3}\right), 1.71,1.61$ $(2 \mathrm{~m}, 2 \mathrm{H}, \mathrm{H}-\beta), 1.39-1.30(\mathrm{~m}, 4 \mathrm{H}, \mathrm{H}-\gamma, \mathrm{H}-\delta) ;{ }^{13} \mathrm{C} \mathrm{NMR}(126 \mathrm{MHz}$, $\left.\left(\mathrm{CD}_{3}\right)_{2} \mathrm{SO}\right): \delta 173.4\left(\mathrm{CO}_{2} \mathrm{H}\right), 168.0(\mathrm{CONH}) 160.7,156.0(\mathrm{CO}-$ Coum), $155.3\left(\mathrm{NHCO}_{2}\right), 152.8$ (Cq-Ar), $151.3\left(\mathrm{Cq}-\mathrm{N}(\mathrm{Me})_{2}\right), 137.7$ (Cq-Ar), $128.3(2 \times \mathrm{CH}-\mathrm{Ar}), 127.7(3 \times \mathrm{CH}-\mathrm{Ar}), 126.0(\mathrm{CH}-\mathrm{Ar})$, 109.3 (CH-Ar), 108.9 (CH-Ar), 108.2 (Cq-Ar), 97.5 (CH-Ar), 65.1 $\left(\mathrm{OCH}_{2}-\mathrm{Ph}\right), 52.00(\mathrm{C}-\alpha), 40.1\left(\mathrm{C}-\varepsilon, 2 \mathrm{xNCH}_{3}\right), 38.4\left(\mathrm{CH}_{2}-\mathrm{Coum}\right)$, $30.6(\mathrm{C}-\beta), 29.0(\mathrm{C}-\delta), 22.7(\mathrm{C}-\gamma)$; HPLC (method A-2): $t_{\mathrm{R}}=14.4$ min; HPLC-MS (method B): $t_{\mathrm{R}}=13.7 \mathrm{~min}$; MS: $\left(\mathrm{ESI}^{+}\right), \mathrm{m} / z(\%)$ : $[\mathrm{M}+\mathrm{H}]^{+}=510.1(100 \%),\left[\mathrm{M}-\mathrm{CO}_{2}+\mathrm{H}\right]^{+}=466.3(20 \%) ; \mathrm{MS}:$ $\left(\mathrm{ESI}^{-}\right), m / z(\%):[\mathrm{M}-\mathrm{H}]^{-}=508.3(100 \%):$ HRMS $\left(\mathrm{ESI}^{-}\right)$calcd for $\left[\mathrm{C}_{27} \mathrm{H}_{31} \mathrm{~N}_{3} \mathrm{O}_{7}-\mathrm{H}\right]^{-}: 508.2089$; found: $508.2089 ; \lambda_{\text {abs }}^{\max }=373 \mathrm{~nm}$, $\lambda_{\mathrm{em}}^{\max }=448 \mathrm{~nm}, \Phi=0.714, \varepsilon\left(\lambda_{\max }\right)=16,800 \mathrm{M}^{-1} \mathrm{~cm}^{-1}$.

$N^{6}$-((Benzyloxy) carbonyl- $N^{2}-(2-$ (7-(diethylamino)-2-oxo- $2 \mathrm{H}$ chromen-4-yl)acetyl)-L-lysine (38). From 7-diethylamino-4-carboxymethyl-coumarin $30(0.275 \mathrm{~g}, 1.0 \mathrm{mmol}, 1$ equiv), $\mathrm{HCl} \cdot \mathrm{Lys}(\mathrm{Cbz})$ OMe (0.360 g, $1.2 \mathrm{mmol}, 1.2$ equiv), HBTU (0.440 g, $1.2 \mathrm{mmol}, 1.2$ equiv), and DIEA ( $865 \mu \mathrm{L}, 5.0 \mathrm{mmol}, 5$ equiv), compound 38 (0.128 g) was obtained by filtration as a yellow powder in a $19 \%$ yield according to general procedure B. ${ }^{1} \mathrm{H}$ NMR $\left(500 \mathrm{MHz},\left(\mathrm{CD}_{3}\right)_{2} \mathrm{SO}\right)$ : $\delta 8.54(\mathrm{~d}, J=7.5 \mathrm{~Hz}, 1 \mathrm{H}, \mathrm{NH}), 7.52(\mathrm{~d}, J=9.0 \mathrm{~Hz}, 1 \mathrm{H}, \mathrm{H}-5), 7.30$ $(\mathrm{m}, 6 \mathrm{H}, \mathrm{H}-\mathrm{Ph}, \mathrm{NH}), 6.66(\mathrm{dd}, J=9.0 \mathrm{~Hz}, J=2.5 \mathrm{~Hz}, 1 \mathrm{H}, \mathrm{H}-6), 6.54$ (d, $J=2.5 \mathrm{~Hz}, 1 \mathrm{H}, \mathrm{H}-8), 5.99$ (s, $1 \mathrm{H}, \mathrm{H}-3), 5.00\left(\mathrm{~s}, 2 \mathrm{H}, \mathrm{CH}_{2}-\mathrm{Ph}\right)$, $4.15(\mathrm{~m}, 1 \mathrm{H}, \mathrm{H}-\alpha), 3.65\left(\mathrm{~s}, 2 \mathrm{H}, \mathrm{CH}_{2}\right.$-Coum $), 3.41(\mathrm{q}, J=7.0 \mathrm{~Hz}, 4 \mathrm{H}$, $\left.\mathrm{N}\left(\mathrm{CH}_{2} \mathrm{CH}_{3}\right)_{2}\right), 2.96(\mathrm{~m}, 2 \mathrm{H}, \mathrm{H}-\varepsilon), 1.72,1.60(2 \mathrm{~m}, 2 \mathrm{H}, \mathrm{H}-\beta), 1.45-$ $1.26(\mathrm{~m}, 4 \mathrm{H}, \mathrm{H}-\gamma, \mathrm{H}-\delta), 1.10\left(\mathrm{t}, J=7.0 \mathrm{~Hz}, 6 \mathrm{H}, \mathrm{N}\left(\mathrm{CH}_{2} \mathrm{CH}_{3}\right)_{2}\right) ;{ }^{13} \mathrm{C}$ NMR (126 MHz, $\left.\left(\mathrm{CD}_{3}\right)_{2} \mathrm{SO}\right): \delta 173.4\left(\mathrm{CO}_{2} \mathrm{H}\right), 168.0(\mathrm{CONH})$, 160.7, 156.0 (CO-Coum), $155.7\left(\mathrm{NHCO}_{2}\right), 151.2$ (Cq-Ar), 150.3 $\left(\mathrm{Cq}-\mathrm{N}(\mathrm{Me})_{2}\right), 137.3$ (Cq-Ar), $128.3(2 \times \mathrm{CH}-\mathrm{Ar}), 127.7(3 \times \mathrm{CH}-$ $\mathrm{Ar}), 126.3$ (CH-Ar), 108.8 (CH-Ar), 108.5 (CH-Ar), 107.7 (Cq-Ar), 96.8 (CH-Ar), $65.1\left(\mathrm{OCH}_{2}-\mathrm{Ph}\right), 52.0(\mathrm{C}-\alpha), 44.0\left(2 \times \mathrm{NCH}_{2} \mathrm{CH}_{3}\right)$, 40.1 (C- $\varepsilon$ ), $38.4\left(\mathrm{CH}_{2}\right.$-Coum), $30.6(\mathrm{C}-\beta), 29.0(\mathrm{C}-\delta), 22.7(\mathrm{C}-\gamma)$, $12.3\left(2 \times \mathrm{NCH}_{2} \mathrm{CH}_{3}\right)$; HPLC (method A-2): $t_{\mathrm{R}}=15.9$ min; HPLCMS (method B): $t_{\mathrm{R}}=14.7 \mathrm{~min} ; \mathrm{MS}:\left(\mathrm{ESI}^{+}\right), m / z(\%):[\mathrm{M}+\mathrm{H}]^{+}=$ $538.1(100 \%),[2 \mathrm{M}+\mathrm{H}]^{+}=1074.9(90 \%),\left[\mathrm{M}-\mathrm{CO}_{2}+\mathrm{H}\right]^{+}=494.4$ (20\%); HRMS $\left(\mathrm{ESI}^{-}\right)$calcd for $\left[\mathrm{C}_{29} \mathrm{H}_{35} \mathrm{~N}_{3} \mathrm{O}_{7}-\mathrm{H}\right]^{-}:$536.2402; found: $536.2402 ; \lambda_{\mathrm{abs}}^{\max }=379 \mathrm{~nm}, \lambda_{\mathrm{em}}^{\max }=446 \mathrm{~nm}, \varepsilon\left(\lambda_{\max }\right)=18,600 \mathrm{M}^{-1}$ $\mathrm{cm}^{-1}, \Phi=0.749$.

$N^{6}$-((Benzyloxy)carbonyl- $N^{2}-(2-o x o-1,2-d i h y d r o q u i n o l i n e-4-c a r-$ bonyl)-L-lysine (39). From 4-carboxy-quinolin-2-one (0.189 g, 1.0 mmol, 1 equiv), $\mathrm{HCl} \cdot \mathrm{Lys}(\mathrm{Cbz})-\mathrm{OMe}(0.364 \mathrm{~g}, 1.1 \mathrm{mmol}, 1.1$ equiv), HBTU ( $0.420 \mathrm{~g}, 1.1 \mathrm{mmol}, 1.1$ equiv), and DIEA ( $692 \mu \mathrm{L}, 4 \mathrm{mmol}, 4$ equiv), compound 39 ( $0.168 \mathrm{~g})$ was obtained after purification by column chromatography on silica gel $\left(\mathrm{CH}_{2} \mathrm{Cl}_{2} / \mathrm{MeOH} / \mathrm{AcOH}\right.$ : 85 / $15 / 1)$ as a white powder in a $43 \%$ yield, according to general procedure B. mp: $214-215{ }^{\circ} \mathrm{C}$; ${ }^{1} \mathrm{H}$ NMR $\left(500 \mathrm{MHz},\left(\mathrm{CD}_{3}\right)_{2} \mathrm{SO}\right): \delta$ 11.94 (brs, $1 \mathrm{H}, \mathrm{CO}_{2} \mathrm{H}$ ), 8.51 (d, $\left.J=7.5 \mathrm{~Hz}, 1 \mathrm{H}, \mathrm{H}-\mathrm{Ar}\right), 7.80$ (d, $J=$ $8.5 \mathrm{~Hz}, 1 \mathrm{H}, \mathrm{NH}), 7.50(\mathrm{t}, J=7.5 \mathrm{~Hz}, 1 \mathrm{H}, \mathrm{H}-\mathrm{Ar}), 7.35-7.21(\mathrm{~m}, 7 \mathrm{H}$, $\mathrm{H}-\mathrm{Ar}, \mathrm{H}-\mathrm{Ph}$ ), 7.17 (t, J = $7.5 \mathrm{~Hz}, 1 \mathrm{H}, \mathrm{H}-\mathrm{Ar}), 6.53$ (s, 1H, H-Ar), 4.98 (s, $2 \mathrm{H}, \mathrm{CH}_{2}-\mathrm{Ph}$ ), 4.27 (m, 1H, H- $\alpha$ ), 2.99 (m, $\left.2 \mathrm{H}, \mathrm{H}-\varepsilon\right), 1.85,1.64$
$(2 \mathrm{~m}, 2 \mathrm{H}, \mathrm{H}-\beta), 1.46-1.34(\mathrm{~m}, 4 \mathrm{H}, \mathrm{H}-\gamma, \mathrm{H}-\delta) ;{ }^{13} \mathrm{C}$ NMR $(126 \mathrm{MHz}$, $\left.\left(\mathrm{CD}_{3}\right)_{2} \mathrm{SO}\right): \delta 173.0\left(\mathrm{CO}_{2} \mathrm{H}\right), 165.3(\mathrm{CONH}-\mathrm{Ar}), 161.4(\mathrm{CO}-\mathrm{Ar})$ $156.0\left(\mathrm{NHCO}_{2}\right), 146.6$ (Cq-Ar), 139.2 (Cq-Ar), 137.3 (Cq-Ar), 130.6 (CH-Ar), 128.3 ( $2 \times \mathrm{CH}-\mathrm{Ar}), 127.6$ (3 $\times \mathrm{CH}-\mathrm{Ar}), 126.2$ (Cq$\mathrm{Ar}$ ), 121.9 (CH-Ar), 119.5 (CH-Ar), 116.4 (CH-Ar), 115.5 (CH-Ar), $65.1\left(\mathrm{OCH}_{2}-\mathrm{Ph}\right), 53.6(\mathrm{C}-\alpha), 40.2(\mathrm{C}-\varepsilon), 31.1(\mathrm{C}-\beta), 29.2(\mathrm{C}-\delta)$, $23.0(\mathrm{C}-\gamma)$; HPLC (method A-2): $t_{\mathrm{R}}=12.8 \mathrm{~min}$; HPLC-MS (method B): $t_{\mathrm{R}}=11.8 \mathrm{~min}$; MS: $\left(\mathrm{ESI}^{+}\right), m / z(\%):[\mathrm{M}+\mathrm{H}]^{+}=452.3(100 \%)$, $\left[\mathrm{M}-\mathrm{CO}_{2}+\mathrm{H}\right]^{+}=408.3(20 \%)$; $\mathrm{MS}:\left(\mathrm{ESI}^{-}\right), m / z(\%):[\mathrm{M}-\mathrm{H}]^{-}=$ $450.6(20 \%) ;[2 \mathrm{M}-\mathrm{H}]^{-}=902.0(100 \%)$; HRMS $\left(\mathrm{ESI}^{-}\right)$calcd for $\left[\mathrm{C}_{24} \mathrm{H}_{25} \mathrm{~N}_{3} \mathrm{O}_{6}-\mathrm{H}\right]^{-}:$450.1670; found: 450.1669; $\lambda_{\mathrm{abs}}^{\max }=332 \mathrm{~nm}$, $\lambda_{\mathrm{em}}^{\max }=434 \mathrm{~nm}, \varepsilon\left(\lambda_{\max }\right)=16,700 \mathrm{M}^{-1} \mathrm{~cm}^{-1}, \Phi=0.0101$.

$N^{6}-\left(\left(\right.\right.$ Benzyloxy) carbonyl- $N^{2}-(3-(3,6-$ dihydroxy-9H-xanthen-9ylidene)propanoyl)-L-lysine (40). From compound 32 (0.384 g, 1.0 mmol, 1 equiv), HBTU ( $0.417 \mathrm{~g}, 1.1 \mathrm{mmol}, 1.1$ equiv), and HOBt $(0.148 \mathrm{~g}, 1.1 \mathrm{mmol}, 1.1$ equiv) were diluted with anhydrous DMF (3 $\mathrm{mL}$ ). DIEA ( $380 \mu \mathrm{L}, 2.2 \mathrm{mmol}, 2.2$ equiv) was added dropwise, and this solution was stirred for a few minutes then a solution of $\mathrm{HCl}$. Lys $(\mathrm{Cbz})$-OMe $(0.331 \mathrm{~g}, 1.0 \mathrm{mmol}, 1$ equiv) in DMF $(1 \mathrm{~mL})$ was added. The solution was stirred overnight at room temperature then the solvent was evaporated, and the residue was diluted in EtOAc (50 $\mathrm{mL})$. The organic layer was washed with brine $(3 \times 40 \mathrm{~mL})$, dried $\left(\mathrm{Na}_{2} \mathrm{SO}_{4}\right)$, filtered, and evaporated. The mixture was diluted with a solution of aqueous $\mathrm{LiOH}(0.5 \mathrm{M}) / \mathrm{THF}(40 \mathrm{~mL}, 1 / 1)$ and stirred 2 $\mathrm{h}$ at room temperature. After evaporation of THF, the $\mathrm{pH}$ was adjusted to 2 with aqueous $\mathrm{HCl}$ solution $(1 \mathrm{M})$ and extracted with EtOAc $(2 \times 40 \mathrm{~mL})$. The organic layer was dried $\left(\mathrm{Na}_{2} \mathrm{SO}_{4}\right)$, filtered, and evaporated. The residue was purified by column chromatography on silica gel $\left(\mathrm{CH}_{2} \mathrm{Cl}_{2} / \mathrm{MeOH} / \mathrm{AcOH}\right.$ : $\left.85 / 15 / 1\right)$. Compound 40 $(0.045 \mathrm{~g})$ was obtained as a red powder in an $8 \%$ yield. mp: $106-107$ ${ }^{\circ} \mathrm{C}$; ${ }^{1} \mathrm{H}$ NMR $\left(126 \mathrm{MHz},\left(\mathrm{CD}_{3}\right)_{2} \mathrm{SO}\right): \delta 7.51(\mathrm{~d}, J=8.5 \mathrm{~Hz}, 1 \mathrm{H}, \mathrm{H}-$ $\mathrm{Ar}$ ), 7.41 (d, $J=8.5 \mathrm{~Hz}, 1 \mathrm{H}, \mathrm{H}-\mathrm{Ar}), 7.15$ (m, 5H, H-Ph), 6.59-6.45 (m, $4 \mathrm{H}, \mathrm{H}-\mathrm{Ar}), 5.78(\mathrm{t}, J=7.0 \mathrm{~Hz}, 1 \mathrm{H}, \mathrm{C}=\mathrm{CH}), 4.69\left(\mathrm{~s}, 2 \mathrm{H}, \mathrm{CH}_{2-}\right.$ $\mathrm{Ph}), 4.25(\mathrm{~m}, 1 \mathrm{H}, \mathrm{H}-\alpha), 3.31\left(\mathrm{~d}, J=7.0 \mathrm{~Hz}, 2 \mathrm{H}, \mathrm{CH}_{2}-\mathrm{CH}\right), 2.88(\mathrm{~m}$ $2 \mathrm{H}, \mathrm{H}-\varepsilon), 1.70,1.55(\mathrm{~m}, 2 \mathrm{H}, \mathrm{H}-\beta), 1.29-1.18(\mathrm{~m}, 4 \mathrm{H}, \mathrm{H}-\gamma, \mathrm{H}-\delta) ;{ }^{13} \mathrm{C}$ NMR $\left(126 \mathrm{MHz},\left(\mathrm{CD}_{3}\right)_{2} \mathrm{SO}\right): \delta 172.9\left(\mathrm{CO}_{2} \mathrm{H}\right), 164.8(\mathrm{CONH})$, 158.2, 157.9 (Cq-3, Cq-6), 156.0 (NHCO), 153.0 (Cq-Ar), 151.3 (Cq-Ar), 138.7 (Cq-Ar), 128.3 (CH-Ar), 128.1 (2 × CH-Ar), 127.2 $(3 \times \mathrm{CH}-\mathrm{Ar}), 125.7$ (Cq-Ar), 123.3, 115.7 (CH-Ar), 114.0, 113.1 (Cq-Ar), 112.0 (CH-Ar), 110.8 (=CH), 103.0 (CH-Ar), $102.4(\mathrm{CH}-$ $\mathrm{Ar}), 66.1\left(\mathrm{OCH}_{2} \mathrm{Ph}\right), 52.6(\mathrm{C}-\alpha), 40.6(\mathrm{C}-\varepsilon), 36.3\left(\mathrm{CH}_{2} \mathrm{CO}\right), 31.0$ $(\mathrm{C}-\beta), 29.1(\mathrm{C}-\delta), 22.6(\mathrm{C}-\gamma)$; HPLC (method A-2): $t_{\mathrm{R}}=13.7$ and $15.1 \mathrm{~min} ;$ HPLC-MS (method B): $t_{\mathrm{R}}=12.1$ and $12.9 \mathrm{~min}(2$ tautomers); MS: $\left(\mathrm{ESI}^{+}\right), \mathrm{m} / z(\%):[\mathrm{M}+\mathrm{H}]^{+}=547.2(100 \%)$; $\mathrm{MS}$ : $\left(\mathrm{ESI}^{-}\right), m / z(\%):[\mathrm{M}-\mathrm{H}]^{-}=545.3(100 \%),\left[\mathrm{M}-\mathrm{C}_{7} \mathrm{H}_{7} \mathrm{O}-\mathrm{H}\right]^{-}=$ $438.2(30 \%)$; HRMS $\left(\mathrm{ESI}^{-}\right)$calcd for $\left[\mathrm{C}_{30} \mathrm{H}_{30} \mathrm{~N}_{2} \mathrm{O}_{8}-\mathrm{H}\right]^{-}$: 545.1929; found: $545.1956 ; \lambda_{\mathrm{abs}}^{\max }=455 \mathrm{~nm}, \lambda_{\mathrm{em}}^{\max }=516 \mathrm{~nm}, \varepsilon\left(\lambda_{\max }\right)$ $=5140 \mathrm{M}^{-1} \mathrm{~cm}^{-1}, \Phi=0.243$.

$N^{6}$-((Benzyloxy)carbonyl-N²-(2-(11-oxo-2,3,6,7-tetrahydro$1 \mathrm{H}, 5 \mathrm{H}, 11 \mathrm{H}$-pyrano[2,3-f]pyrido[3,2,1-ij]quinolin-9-yl))acetyl)-L-lysine (41). From compound 31 ( $0.150 \mathrm{~g}, 0.50 \mathrm{mmol}, 1$ equiv), $\mathrm{HCl}$. Lys(Cbz)-OMe (0.182 g, $0.55 \mathrm{mmol}, 1.1$ equiv), HBTU (0.209 g, $0.55 \mathrm{mmol}, 1.1$ equiv), and DIEA (346 $\mu \mathrm{L}, 2.0 \mathrm{mmol}, 4$ equiv), compound $41(0.033 \mathrm{~g})$ was obtained by filtration as a yellow powder in a $12 \%$ yield according to general procedure $\mathrm{B} .{ }^{1} \mathrm{H}$ NMR $(500 \mathrm{MHz}$, $\left.\mathrm{CD}_{3} \mathrm{OD}\right): \delta 7.40(\mathrm{~m}, 5 \mathrm{H}, \mathrm{H}-\mathrm{Ph}) 7.15(\mathrm{~s}, 1 \mathrm{H}, \mathrm{H}-8), 6.01(\mathrm{~s}, 1 \mathrm{H}, \mathrm{H}-$ 10), $5.06\left(\mathrm{~s}, 2 \mathrm{H}, \mathrm{CH}_{2}-\mathrm{Ph}\right), 4.40(\mathrm{~m}, 1 \mathrm{H}, \mathrm{H}-\alpha), 3.72\left(\mathrm{~s}, 2 \mathrm{H}, \mathrm{CH}_{2}\right.$ Coum), $3.27\left(\mathrm{~m}, 4 \mathrm{H}, \mathrm{CH}_{2} \mathrm{~N}\right), 2.84-2.71\left(\mathrm{~m}, 6 \mathrm{H}, 2 \times \mathrm{CH}_{2}-\mathrm{Ar}, \mathrm{H}-\varepsilon\right)$, 1.98-1.91 (m, 5H, $\left.2 \times \mathrm{CH}_{2}-\mathrm{CH}_{2}-\mathrm{CH}_{2}, \mathrm{H}-\beta\right), 1.75(\mathrm{~m}, 1 \mathrm{H}, \mathrm{H}-\beta)$, $1.62-1.41(\mathrm{~m}, 4 \mathrm{H}, \mathrm{H}-\gamma, \mathrm{H}-\delta) ;{ }^{13} \mathrm{C}$ NMR $\left(126 \mathrm{MHz}, \mathrm{CD}_{3} \mathrm{OD}\right): \delta$ $175.6\left(\mathrm{CO}_{2} \mathrm{H}\right), 171.6(\mathrm{CONH}), 165.3,161.4$ (CO-Coum), 159.1 $\left(\mathrm{NHCO}_{2}\right), 152.7,152.3,147.7$ (Cq-Ar), 138.3 (Cq-Ar), $129.6(2 \times$ CH-Ar), 129.1(CH-Ar), 128.8 ( $3 \times$ CH-Ar), 123.3 (CH-Ar), 118.7 (Cq-Ar), 109.2 (CH-Ar), 108.8 (Cq-Ar), $67.5\left(\mathrm{OCH}_{2}-\mathrm{Ph}\right), 51.0$ (C$\alpha), 50.5,50.4\left(\mathrm{CH}_{2}-\mathrm{N}\right), 41.5\left(\mathrm{CH}_{2}\right.$-Coum $), 40.1(\mathrm{C}-\varepsilon), 32.0(\mathrm{C}-\beta)$, $30.8(\mathrm{C}-\delta), 28.8\left(\mathrm{CH}_{2}\right), 24.1(\mathrm{C}-\gamma), 22.5,21.6,21.4\left(\mathrm{CH}_{2}\right)$; HPLC $(\operatorname{method} \mathrm{A}-2): t_{\mathrm{R}}=17.0 \mathrm{~min}$; HPLC-MS $(\operatorname{method} \mathrm{B}): t_{\mathrm{R}}=15.0 \mathrm{~min}$; MS: $\left(\mathrm{ESI}^{-}\right), m / z(\%):[\mathrm{M}-\mathrm{H}]^{-}=560.5(100 \%),\left[\mathrm{M}-\mathrm{C}_{7} \mathrm{H}_{8} \mathrm{O}-\right.$ $\mathrm{H}]^{-}=452.4(30 \%)$; HRMS: $\left(\mathrm{ESI}^{-}\right)$calcd for $\left[\mathrm{C}_{31} \mathrm{H}_{35} \mathrm{~N}_{3} \mathrm{O}_{7}-\mathrm{H}\right]^{-}$: 
560.2402; found: $560.2424 ; \lambda_{\mathrm{abs}}^{\max }=395 \mathrm{~nm}, \lambda_{\mathrm{em}}^{\max }=487 \mathrm{~nm}, \varepsilon\left(\lambda_{\max }\right)=$ $8870 \mathrm{M}^{-1} \mathrm{~cm}^{-1}, \Phi=0.736$.

$N^{6}$-((Benzyloxy)carbonyl- $N^{2}-(((7-h y d r o x y-2-o x o-2 H-c h r o m e n-4-$ yl)methoxy)carbonyl)-L-lysine (42). 7-Hydroxy-4-hydroxy methylcoumarin 27 ( $0.150 \mathrm{~g}, 0.78 \mathrm{mmol}, 1$ equiv) and CDI (0.156 g, 0.93 mmol, 1.2 equiv) were added in dry DMF $(2 \mathrm{~mL})$, and the solution was stirred for $3 \mathrm{~h}$ at room temperature leading to a white precipitate. $\mathrm{HCl} \cdot \mathrm{Lys}(\mathrm{Cbz})-\mathrm{OMe}$ ( $0.307 \mathrm{~g}, 0.93 \mathrm{mmol}, 1.2$ equiv) and DIEA (215 $\mu \mathrm{L}, 1.25 \mathrm{mmol}, 1.6$ equiv) were added in solution and heated to 80 ${ }^{\circ} \mathrm{C}$ for $1.5 \mathrm{~h}$. After cooling to room temperature, the $\mathrm{pH}$ was adjusted to 3 with aqueous $\mathrm{HCl}(1 \mathrm{M})$ and the solution was extracted with EtOAc $(2 \times 30 \mathrm{~mL})$. The organic layer was washed with $\mathrm{H}_{2} \mathrm{O}(2 \times 20$ $\mathrm{mL})$, dried $\left(\mathrm{Na}_{2} \mathrm{SO}_{4}\right)$, filtered, and evaporated. After purification by column chromatography on silica gel (EtOAc), the ester compound was diluted with a solution of aqueous $\mathrm{LiOH}(0.5 \mathrm{M}) / \mathrm{THF}(3 \mathrm{~mL}$, $1 / 1$ ) and stirred at room temperature for $2 \mathrm{~h}$. THF was removed under vacuum, and the $\mathrm{pH}$ was adjusted to 2 with aqueous $\mathrm{HCl}$ solution $(1 \mathrm{M})$ then extracted with EtOAc $(2 \times 15 \mathrm{~mL})$. Organic layers were dried $\left(\mathrm{Na}_{2} \mathrm{SO}_{4}\right)$, filtered, and evaporated. The residue was purified by column chromatography on silica gel $\left(\mathrm{CH}_{2} \mathrm{Cl}_{2} / \mathrm{MeOH} /\right.$ AcOH: 85/15/1). Compound $42(0.080 \mathrm{~g})$ was obtained as a white gum in a $21 \%$ yield. mp: $72-73{ }^{\circ} \mathrm{C} ;{ }^{1} \mathrm{H}$ NMR $\left(500 \mathrm{MHz}, \mathrm{CD}_{3} \mathrm{OD}\right): \delta$ $7.44(\mathrm{~d}, J=9.0 \mathrm{~Hz}, 1 \mathrm{H}, \mathrm{H}-5), 7.28(\mathrm{~m}, 5 \mathrm{H}, \mathrm{H}-\mathrm{Ph}), 6.76$ (dd, $J=8.5$ $\mathrm{Hz}, J=2.5 \mathrm{~Hz}, 1 \mathrm{H}, \mathrm{H}-6), 6.68$ (d, $J=2.5 \mathrm{~Hz}, 1 \mathrm{H}, \mathrm{H}-8), 6.24(\mathrm{~s}, 1 \mathrm{H}$, $\mathrm{H}-3), 5.25\left(\mathrm{~s}, 2 \mathrm{H}, \mathrm{CH}_{2}-\mathrm{Ph}\right), 5.02\left(\mathrm{~s}, 2 \mathrm{H}, \mathrm{CH}_{2}-\mathrm{Coum}\right), 4.18(\mathrm{~m}, 1 \mathrm{H}$, $\mathrm{H}-\alpha), 3.11(\mathrm{t}, J=6.5 \mathrm{~Hz}, 2 \mathrm{H}, \mathrm{H}-\varepsilon), 1.87,1.72(2 \mathrm{~m}, 2 \mathrm{H}, \mathrm{H}-\beta), 1.54-$ $1.42(\mathrm{~m}, 4 \mathrm{H}, \mathrm{H}-\gamma, \mathrm{H}-\delta) ;{ }^{13} \mathrm{C}$ NMR (126 MHz, CD $\left.3 \mathrm{OD}\right): \delta 175.3$ $\left(\mathrm{CO}_{2} \mathrm{H}\right), 163.5,163.0,158.9(\mathrm{Cq}-\mathrm{O}), 157.7$ (Cq-Ar), 156.7 $\left(\mathrm{NHCO}_{2}\right), 153.2,138.4(\mathrm{Cq}-\mathrm{Ar}), 129.5(2 \times \mathrm{CH}-\mathrm{Ar}), 128.9(\mathrm{CH}-$ $\mathrm{Ar}), 128.7$ ( $2 \times \mathrm{CH}-\mathrm{Ar}), 126.4(\mathrm{CH}-\mathrm{Ar}), 114.6(\mathrm{CH}-\mathrm{Ar}), 111.0(\mathrm{Cq}-$ $\mathrm{Ar}), 108.9$ (CH-Ar), 103.9 (CH-Ar), $67.4\left(\mathrm{OCH}_{2}-\mathrm{Ph}\right), 62.0\left(\mathrm{CH}_{2}-\right.$ Coum), 52.9 (C- $\alpha$ ), 41.6 (C- $\varepsilon$ ), 32.4 (C- $\beta)$, 30.4 (C- $\delta$ ), 24.1 (C- $\gamma)$; HPLC (method A-2): $t_{\mathrm{R}}=13.9$ min; HPLC-MS $(\operatorname{method} \mathrm{B}): t_{\mathrm{R}}=$ 12.9 min; MS: $\left(\mathrm{ESI}^{+}\right), \mathrm{m} / z(\%):[\mathrm{M}+\mathrm{H}]^{+}=499.1(50 \%) ;[2 \mathrm{M}+$ $\mathrm{Na}]^{+}=1019.0(100 \%) ; \mathrm{MS}:\left(\mathrm{ESI}^{-}\right), m / z(\%):[\mathrm{M}-\mathrm{H}]^{-}=497.2$ (100\%); HRMS $\left(\mathrm{ESI}^{-}\right)$calcd for $\left[\mathrm{C}_{25} \mathrm{H}_{26} \mathrm{~N}_{2} \mathrm{O}_{9}-\mathrm{H}\right]^{-}:$: 497.1565; found: $497.1567 ; \lambda_{\mathrm{abs}}^{\max }=324 \mathrm{~nm}, \lambda_{\mathrm{em}}^{\max }=395 \mathrm{~nm}, \varepsilon\left(\lambda_{\max }\right)=11,200 \mathrm{M}^{-1}$ $\mathrm{cm}^{-1}, \Phi=0.12$.

$N^{2}-\left(((9 H-F l u o r e n-9-y l) m e t h o x y)\right.$ carbonyl)- $N^{6}-(2-$-(7-(dimethylamino)-2-oxo-2H-chromen-4-yl)acetyl)-L-lysine (44). From 7-dimethylamino-4-carboxymethyl-coumarin $29(0.247 \mathrm{~g}, 1.0 \mathrm{mmol}, 1$ equiv), Fmoc-Lys-OMe 43 (0.442 g, 1.0 mmol, 1 equiv), HBTU (416 mg, 1.1 mmol, 1.1 equiv), and DIEA ( $865 \mu \mathrm{L}, 5.0 \mathrm{mmol}, 5$ equiv), compound $44(0.030 \mathrm{~g})$ was obtained after purification by column chromatography on silica gel $\left(\mathrm{CH}_{2} \mathrm{Cl}_{2} / \mathrm{MeOH} / \mathrm{AcOH}\right.$ : $\left.85 / 15 / 1\right)$ as a yellow powder in a $5 \%$ yield, according to general procedure $\mathrm{B} .{ }^{1} \mathrm{H}$ NMR (500 MHz, $\left.\mathrm{CD}_{3} \mathrm{OD}\right): \delta 7.76(\mathrm{~d}, J=7.5 \mathrm{~Hz}, 2 \mathrm{H}, \mathrm{H}-\mathrm{Ar}), 7.64(\mathrm{~d}, J=$ $7.5 \mathrm{~Hz}, 2 \mathrm{H}, \mathrm{H}-\mathrm{Ar}), 7.51(\mathrm{~d}, J=9.0 \mathrm{~Hz}, 1 \mathrm{H}, \mathrm{H}-5), 7.36(\mathrm{t}, J=7.5 \mathrm{~Hz}$, $2 \mathrm{H}, \mathrm{H}-\mathrm{Ar}), 7.28(\mathrm{t}, J=7.5 \mathrm{~Hz}, 2 \mathrm{H}, \mathrm{H}-\mathrm{Ar}), 6.71(\mathrm{dd}, J=9.0 \mathrm{~Hz}, J=$ $2.5 \mathrm{~Hz}, 1 \mathrm{H}, \mathrm{H}-6), 6.48$ (d, $J=2.5 \mathrm{~Hz}, 1 \mathrm{H}, \mathrm{H}-8), 6.02(\mathrm{~s}, 1 \mathrm{H}, \mathrm{H}-3)$, $4.33\left(\mathrm{~d}, J=6.0 \mathrm{~Hz}, 2 \mathrm{H}, \mathrm{OCH}_{2} \mathrm{CH}\right), 4.18(\mathrm{t}, J=6.0 \mathrm{~Hz}, 1 \mathrm{H}$, $\left.\mathrm{OCH}_{2} \mathrm{CH}\right), 4.09(\mathrm{~m}, 1 \mathrm{H}, \mathrm{H}-\alpha), 3.64\left(\mathrm{~s}, 2 \mathrm{H}, \mathrm{CH}_{2}\right.$-Coum $), 3.21(\mathrm{t}, J=$ $6.5 \mathrm{~Hz}, 2 \mathrm{H}, \mathrm{H}-\varepsilon), 3.01\left(\mathrm{~m}, 6 \mathrm{H}, \mathrm{N}\left(\mathrm{CH}_{3}\right)_{2}\right), 1.84,1.68(2 \mathrm{~m}, 2 \mathrm{H}, \mathrm{H}-\beta)$, $1.56-1.38(\mathrm{~m}, 4 \mathrm{H}, \mathrm{H}-\gamma, \mathrm{H}-\delta) ;{ }^{13} \mathrm{C}$ NMR $\left(126 \mathrm{MHz}, \mathrm{CD}_{3} \mathrm{OD}\right): \delta$ $177.4\left(\mathrm{CO}_{2} \mathrm{H}\right), 167.5$ (CONH), 160.7 (CO-Coum), 155.5, 155.3 (Cq-O, $\left.\mathrm{NHCO}_{2}\right), 152.7$ (Cq-Ar), $151.4(\mathrm{Cq}-\mathrm{N}(\mathrm{Me}) 2), 143.8,140.6$ $(2 \times$ Cq-Fmoc $), 127.5,127.0(2 \times$ CH-Fmoc $), 126.0(\mathrm{CH}-\mathrm{Ar}), 125.2$ $(2 \times \mathrm{CH}$-Fmoc), $120.0(2 \times \mathrm{CH}-\mathrm{Fmoc}), 109.3(\mathrm{CH}-\mathrm{Ar}), 108.9(\mathrm{CH}-$ $\mathrm{Ar}), 108.2$ (Cq-Ar), 97.4 (CH-Ar), $65.2\left(\mathrm{OCH}_{2} \mathrm{CH}\right), 52.00(\mathrm{C}-\alpha)$, $46.7\left(\mathrm{OCH}_{2} \mathrm{CH}\right), 40.1(\mathrm{C}-\varepsilon), 40.0\left(2 \times \mathrm{NCH}_{3}\right), 38.7\left(\mathrm{CH}_{2}\right.$-Coum $)$, $32.0(\mathrm{C}-\beta), 28.9(\mathrm{C}-\delta), 22.7(\mathrm{C}-\gamma)$; HPLC (method A-2): $t_{\mathrm{R}}=17.7$ min; HPLC-MS (method B): $t_{\mathrm{R}}=15.2 \mathrm{~min}$; MS: $($ ESI +$), \mathrm{m} / z(\%)$ : $[\mathrm{M}+\mathrm{H}]^{+}=598.4(100 \%)$; MS: $\left(\mathrm{ESI}^{-}\right), m / z(\%):[\mathrm{M}-\mathrm{H}]^{-}=596.3$ (100\%); HRMS $\left(\mathrm{ESI}^{-}\right)$calcd for $\left[\mathrm{C}_{34} \mathrm{H}_{35} \mathrm{~N}_{3} \mathrm{O}_{7}-\mathrm{H}\right]^{-}:$: 596.24022, found: $596.24084 ; \lambda_{\mathrm{abs}}^{\max }=373 \mathrm{~nm}, \lambda_{\mathrm{em}}^{\max }=447 \mathrm{~nm}, \varepsilon\left(\lambda_{\max }\right)=17,600$ $\mathrm{M}^{-1} \mathrm{~cm}^{-1}, \Phi=0.599$.

$\mathrm{N}$-(((9H-Fluoren-9-yl)methoxy)carbonyl)-S-((7-hydroxy-2-oxo2H-chromen-4-yl)methyl)-L-cysteine (45). 4-Chloromethyl-7-hydroxy-coumarin 25 (0.316 g, $1.5 \mathrm{mmol}, 1$ equiv) and Fmoc-Cys$\mathrm{OH} 16$ (0.515 g, $1.5 \mathrm{mmol}, 1$ equiv) were diluted in dry THF (7.5
$\mathrm{mL}$ ) then DIEA ( $785 \mu \mathrm{L}, 4.5 \mathrm{mmol}, 3$ equiv) was added dropwise, and the solution was stirred overnight at room temperature. After evaporation, the residue was purified by column chromatography on silica gel $\left(\mathrm{CH}_{2} \mathrm{Cl}_{2} / \mathrm{MeOH} / \mathrm{AcOH}\right.$ : $\left.85 / 15 / 1\right)$. Compound $45(0.272$ g) was obtained as a white powder in a $35 \%$ yield. ${ }^{1} \mathrm{H}$ NMR (500 $\mathrm{MHz},\left(\mathrm{CD}_{3}\right)_{2} \mathrm{SO}$ ): $\delta 12.18$ (brs, $\left.1 \mathrm{H}, \mathrm{CO}_{2} \mathrm{H}\right), 11.01$ (brs, $\left.1 \mathrm{H}, \mathrm{OH}\right)$, 7.88 (d, J=7.5 Hz, 2H, H-Ar), 7.71 (d, J=7.0 Hz, 2H, H-Ar), 7.66 (d, $J=8.5 \mathrm{~Hz}, 1 \mathrm{H}, \mathrm{H}-5), 7.40$ (brt, $J=7.5 \mathrm{~Hz}, 3 \mathrm{H}, \mathrm{H}-\mathrm{Ar}, \mathrm{NH}), 7.31$ (t, $J=7.5 \mathrm{~Hz}, 2 \mathrm{H}, \mathrm{H}-\mathrm{Ar}), 6.78$ (dd, $J=8.5 \mathrm{~Hz}, J=2.0 \mathrm{~Hz}, 1 \mathrm{H}, \mathrm{H}-6)$, $6.71(\mathrm{~d}, J=2.0 \mathrm{~Hz}, 1 \mathrm{H}, \mathrm{H}-8), 6.24(\mathrm{~s}, 1 \mathrm{H}, \mathrm{H}-3), 4.29-4.22(\mathrm{~m}, 3 \mathrm{H}$, $\left.\mathrm{OCH}_{2} \mathrm{CH}\right), 4.10(\mathrm{~m}, 1 \mathrm{H}, \mathrm{H}-\alpha)$, 3.91, $3.88\left(\mathrm{AB}, 2 \mathrm{H}, \mathrm{CH}_{2}\right.$-Coum), $2.96(\mathrm{dd}, J=13.5 \mathrm{~Hz}, J=4.0 \mathrm{~Hz}, 1 \mathrm{H}, \mathrm{H}-\beta), 2.80(\mathrm{dd}, J=13.5 \mathrm{~Hz}, J=$ $4.5 \mathrm{~Hz}, 1 \mathrm{H}, \mathrm{H}-\beta)$; ${ }^{13} \mathrm{C}$ NMR (126 MHz, $\left.\left(\mathrm{CD}_{3}\right)_{2} \mathrm{SO}\right): \delta 172.0$ $\left(\mathrm{CO}_{2} \mathrm{H}\right), 161.3$ (Cq-7), 160.1 (CO-Coum), 155.8, 155.4 (Cq-8a, $\left.\mathrm{NHCO}_{2}\right), 152.4(\mathrm{Cq}-4), 143.8(2 \times \mathrm{Cq}-\mathrm{Fmoc}), 140.7(2 \times \mathrm{Cq}-$ Fmoc), 127.6, 127.0 ( $2 \times$ CH-Fmoc), 126.9 (CH-5), $125.2(2 \times \mathrm{CH}-$ Fmoc), 112.8 (CH-6), 110.3 (CH-3), 110.0 (Cq-4a), 102.3 (CH-8), $65.6\left(\mathrm{OCH}_{2} \mathrm{CH}\right), 54.2(\mathrm{C}-\alpha), 46.6\left(\mathrm{OCH}_{2} \mathrm{CH}\right), 33.4(\mathrm{C}-\beta), 31.3$ $\left(\mathrm{CH}_{2}\right.$-Coum); HPLC (method A-1): $t_{\mathrm{R}}=20.3 \mathrm{~min}$; HPLC (method A-2): $t_{\mathrm{R}}=16.2 \mathrm{~min}$; HPLC-MS (method B): $t_{\mathrm{R}}=16.6 \mathrm{~min}$; HPLCMS (method C): $t_{\mathrm{R}}=5.8 \mathrm{~min}$; MS: $\left(\mathrm{ESI}^{+}\right), \mathrm{m} / z(\%):[\mathrm{M}+\mathrm{H}]^{+}=$ 518.2 (100\%); MS: $\left(\mathrm{ESI}^{-}\right), m / z(\%):[\mathrm{M}-\mathrm{H}]^{-}=516.1(100 \%)$; HRMS (ESI ${ }^{-}$) calcd for $\left[\mathrm{C}_{28} \mathrm{H}_{23} \mathrm{NO}_{7} \mathrm{~S}-\mathrm{H}\right]^{-}:$516.1122, found: $516.1126 ; \lambda_{\mathrm{abs}}^{\max }=328 \mathrm{~nm}, \lambda_{\mathrm{em}}^{\max }=399 \mathrm{~nm}, \varepsilon\left(\lambda_{\max }\right)=5960 \mathrm{M}^{-1} \mathrm{~cm}^{-1}, \Phi$ $=0.0922$.

$\mathrm{N}$-(((9H-Fluoren-9-yl)methoxy)carbonyl)-S-((7-methoxy-2-oxo2H-chromen-4-yl)methyl)-L-cysteine (46). 4-Chloromethyl-7-methoxy-coumarin 26 (0.224 g, $1.0 \mathrm{mmol}, 1$ equiv) and Fmoc-Cys$\mathrm{OH} 16$ (0.343 g, $1.0 \mathrm{mmol}, 1$ equiv) were diluted in dry DMF $(8 \mathrm{~mL})$ then $\mathrm{Et}_{3} \mathrm{~N}(278 \mu \mathrm{L}, 2.0 \mathrm{mmol}$, 2 equiv) was added dropwise, and the solution was stirred overnight at room temperature. After evaporation, the residue was purified by column chromatography on silica gel $\left(\mathrm{CH}_{2} \mathrm{Cl}_{2} / \mathrm{MeOH} / \mathrm{AcOH}: 85 / 15 / 1\right)$. Compound 46 (0.152 g) was obtained as a white powder in a $28 \%$ yield. ${ }^{1} \mathrm{H}$ NMR $(500 \mathrm{MHz}$, $\left.\left(\mathrm{CD}_{3}\right)_{2} \mathrm{SO}\right): \delta 7.88(\mathrm{~d}, J=7.5 \mathrm{~Hz}, 2 \mathrm{H}, \mathrm{H}-\mathrm{Ar}), 7.75(\mathrm{~d}, J=8.0 \mathrm{~Hz}, 1 \mathrm{H}$, $\mathrm{H}-\mathrm{Ar}$ ), 7.75 (d, J = 8.0 Hz, 1H, H-Ar), 7.70 (m, 2H, H-Ar), 7.40 (t, $J$ $=7.5 \mathrm{~Hz}, 2 \mathrm{H}, \mathrm{H}-\mathrm{Ar}), 7.30(\mathrm{t}, J=7.5 \mathrm{~Hz}, 3 \mathrm{H}, \mathrm{H}-\mathrm{Ar}, \mathrm{NH}), 6.96(\mathrm{~s}, 1 \mathrm{H}$, H-Ar), 6.89 (d, $J=8.0 \mathrm{~Hz}, 1 \mathrm{H}, \mathrm{H}-\mathrm{Ar}), 6.32(\mathrm{~s}, 1 \mathrm{H}, \mathrm{H}-3), 4.33-4.17$ $\left(\mathrm{m}, 3 \mathrm{H}, \mathrm{OCH}_{2} \mathrm{CH}\right), 4.05(\mathrm{~m}, 1 \mathrm{H}, \mathrm{NHCH}), 3.92\left(\mathrm{~m}, 2 \mathrm{H}, \mathrm{CH}_{2}-\right.$ Coum), $3.82\left(\mathrm{~s}, 3 \mathrm{H}, \mathrm{CH}_{3}\right), 2.98(\mathrm{dd}, J=13.5 \mathrm{~Hz}, J=3.0 \mathrm{~Hz}, 1 \mathrm{H}, \mathrm{H}-$ $\beta), 2.81(\mathrm{dd}, J=12.5 \mathrm{~Hz}, J=8.5 \mathrm{~Hz}, 1 \mathrm{H}, \mathrm{H}-\beta) ;{ }^{13} \mathrm{C} \mathrm{NMR}(126 \mathrm{MHz}$, $\left.\left(\mathrm{CD}_{3}\right)_{2} \mathrm{SO}\right): \delta 172.1\left(\mathrm{CO}_{2} \mathrm{H}\right), 162.2(\mathrm{C}=\mathrm{O}$ Coum $), 159.9(\mathrm{Cq}-$ $\mathrm{OMe}), 155.6,155.3$ (Cq-O, $\left.\mathrm{NHCO}_{2}\right), 152.3$ (Cq-Ar), $143.8(2 \times \mathrm{Cq}-$ $\mathrm{Ar}), 140.6(2 \times \mathrm{Cq}-\mathrm{Ar}), 127.5,127.0(4 \times \mathrm{CH}-\mathrm{Ar}), 126.7(\mathrm{CH}-\mathrm{Ar})$, 125.2, $120.0(4 \times \mathrm{CH}-\mathrm{Ar}), 111.8(\mathrm{CH}-\mathrm{Ar}), 111.3(\mathrm{CH}-\mathrm{Ar}), 111.2$ (Cq-Ar), $100.9(\mathrm{CH}-\mathrm{Ar}), 65.6\left(\mathrm{OCH}_{2} \mathrm{CH}\right), 55.8,55.7\left(\mathrm{C}-\alpha, \mathrm{OCH}_{3}\right)$, $46.6\left(\mathrm{OCH}_{2} \mathrm{CH}\right), 33.7(\mathrm{C}-\beta), 31.3\left(\mathrm{CH}_{2}\right.$-Coum); HPLC (method A$2): t_{\mathrm{R}}=18.0$ min; HPLC-MS $(\operatorname{method} \mathrm{B}): t_{\mathrm{R}}=18.0 \mathrm{~min}$; HPLC-MS $\left(\right.$ method C): $t_{\mathrm{R}}=10.8$; MS: $\left(\mathrm{ESI}^{+}\right), \mathrm{m} / z(\%):[\mathrm{M}+\mathrm{H}]^{+}=532.2$ $(100 \%) ;\left(\mathrm{ESI}^{-}\right), m / z(\%):[\mathrm{M}-\mathrm{H}]^{-}=530.2(60 \%),[2 \mathrm{M}-\mathrm{H}]^{-}=$ $1061.3(100 \%)$; HRMS $\left(\mathrm{ESI}^{-}\right)$calcd for $\left[\mathrm{C}_{29} \mathrm{H}_{25} \mathrm{NO}_{7} \mathrm{~S}-\mathrm{H}\right]^{-}$: 530.1279 , found: $530.1277 ; \lambda_{\mathrm{abs}}^{\max }=324 \mathrm{~nm}, \lambda_{\mathrm{em}}^{\max }=396 \mathrm{~nm}, \varepsilon\left(\lambda_{\max }\right)=$ $8570 \mathrm{M}^{-1} \mathrm{~cm}^{-1}, \Phi=0.0428$.

$\mathrm{N}$-(((9H-Fluoren-9-yl)methoxy)carbonyl)-S-((6-chloro-7-hydroxy2-oxo-2H-chromen-4-yl)methyl)-L-cysteine (47). 4-Chloromethyl-6chloro-7-hydroxy-coumarin 28 (0.049 g, $0.2 \mathrm{mmol}, 1$ equiv) and Fmoc-Cys-OH 16 (0.068 g, $0.2 \mathrm{mmol}, 1$ equiv) were diluted in dry DMF $(2 \mathrm{~mL})$ then DIEA (108 $\mu \mathrm{L}, 0.6 \mathrm{mmol}, 3$ equiv) was added dropwise, and the solution was stirred overnight at room temperature. After evaporation, the residue was purified by column chromatography on silica gel $\left(\mathrm{CH}_{2} \mathrm{Cl}_{2} / \mathrm{MeOH} / \mathrm{AcOH}\right.$ : 90/10/1). Compound $47(0.035 \mathrm{~g})$ was obtained as a white powder in a $32 \%$ yield. ${ }^{1} \mathrm{H} \mathrm{NMR}$ $\left(500 \mathrm{MHz},\left(\mathrm{CD}_{3}\right)_{2} \mathrm{SO}\right): \delta 12.85$ (brs, $\left.1 \mathrm{H}, \mathrm{CO}_{2} \mathrm{H}\right), 11.38$ (brs, $1 \mathrm{H}$, OH-Ar), 7.88 (m, 2H, H-Ar), $7.75(\mathrm{~d}, J=8.0 \mathrm{~Hz}, 1 \mathrm{H}, \mathrm{NH}), 7.71(\mathrm{~d}, J$ $=7.5 \mathrm{~Hz}, 2 \mathrm{H}, \mathrm{H}-\mathrm{Ar}), 7.41(\mathrm{t}, J=7.5 \mathrm{~Hz}, 2 \mathrm{H}, \mathrm{H}-\mathrm{Ar}), 7.31(\mathrm{t}, J=7.5$ $\mathrm{Hz}, 2 \mathrm{H}, \mathrm{H}-\mathrm{Ar}), 6.91$ (s, 1H, H-Ar), $6.31(\mathrm{~s}, 1 \mathrm{H}, \mathrm{H}-3), 4.33-4.15$ (m, $\left.4 \mathrm{H}, \mathrm{OCH}_{2} \mathrm{CH}, \mathrm{H}-\alpha\right), 3.96\left(\mathrm{~m}, 2 \mathrm{H}, \mathrm{CH}_{2}\right.$-Coum), 2.95 (dd, $J=13.5$ $\mathrm{Hz}, J=4.0 \mathrm{~Hz}, 1 \mathrm{H}, \mathrm{H}-\beta), 2.76(\mathrm{dd}, J=13.5 \mathrm{~Hz}, J=10.0 \mathrm{~Hz}, 1 \mathrm{H}, \mathrm{H}-$ $\beta) ;{ }^{13} \mathrm{C}$ NMR $\left(126 \mathrm{MHz},\left(\mathrm{CD}_{3}\right)_{2} \mathrm{SO}\right): \delta 172.0\left(\mathrm{CO}_{2} \mathrm{H}\right), 159.6(\mathrm{CO}-$ Coum), 156.2, 155.9, 155.8, 153.6, 151.4, 143.8, 143.7 (Cq-Ar), 140.7 
$(2 \times$ Cq-Ar) $, 127.5,127.0$ ( $2 \times \mathrm{CH}-\mathrm{Ar}), 126.4$ (CH-Ar), 125.2, 125.1 (CH-Ar), 120.0 ( $2 \times \mathrm{CH}-\mathrm{Ar}), 116.7$ (Cq-Ar), 111.6 (CH-Ar), 110.9 (Cq-Ar), 103.4 (CH-Ar), $65.7\left(\mathrm{OCH}_{2} \mathrm{CH}\right), 53.6(\mathrm{C}-\alpha), 46.6$ $\left(\mathrm{OCH}_{2} \mathrm{CH}\right), 32.7$ (C- $\left.\beta\right), 31.2\left(\mathrm{CH}_{2}-\mathrm{Coum}\right)$; HPLC (method A-2): $t_{\mathrm{R}}=16.8 \mathrm{~min} ;$ HPLC-MS $(\operatorname{method} \mathrm{B}): t_{\mathrm{R}}=17.6 \mathrm{~min}$; HPLC-MS $(\operatorname{method} \mathrm{C}): t_{\mathrm{R}}=8.9 \mathrm{~min}$; MS: $\left(\mathrm{ESI}^{+}\right), \mathrm{m} / z(\%):[\mathrm{M}+\mathrm{H}]^{+}=552.1$ (100\%); MS: $\left(\mathrm{ESI}^{-}\right), m / z(\%):[\mathrm{M}-\mathrm{H}]^{-}=550.1(100 \%)$.

Modeling and Docking Computation. Homology Modeling. The human sequence of sialin was retrieved from the UniProt database $^{59}$ under the code Q9NRA2. The DgoT template structures $6 \mathrm{E} 9 \mathrm{~N}$ and $6 \mathrm{E} 90^{51}$ were retrieved form the Protein Data Bank. Sequence alignment was carried out using CLUSTAL $\mathrm{W}^{60}$ as implemented in Discovery Studio (Dassault Systèmes BIOVIA, Discovery Studio, 2019) and further refined manually. The model was generated using MODELER, ${ }^{61}$ and the best out of 100 models was selected according to the PDF total energy.

Molecular Docking. Flexible docking of $\mathbf{4 5}$ to the inward-facing model was carried out using GOLD. ${ }^{53}$ A set of nine residues with flexible side chains was used to define the binding site: F50, Y54, R57, F115, F116, Y119, F179, Y306, and Y335. The Goldscore was used to keep the best 10 out of 100 poses. Then, the pose that showed the best orientation according to the hypothesis made from the biological data was selected and further refined through molecular dynamic simulation.

Molecular Dynamics Simulations. The system with proteins and ligands was prepared in the CHARMM-GUI web server ${ }^{62}$ in order to generate a membrane around the protein and solvate with water and ions. A heterogeneous membrane made of 90\% POPG and 10\% cholesterol was chosen, and a TIP3 water model with $\mathrm{NaCl}(0.15 \mathrm{M})$ counter ions was chosen for the solvation. The system was typed with a CHARMM $36 \mathrm{~m}$ force field, and NAMD 2.13 was used. The system was equilibrated through six constrained simulations for a total of 690 ps by gradually diminishing the force constraints at each steps. The following constraints were applied (each value represents an equilibration step): protein backbone $(10 / 5 / 2.5 / 1 / 0.5 / 0.1 \mathrm{kcal} /$ $\mathrm{mol})$, protein side chains $(5 / 2.5 / 1.25 / 0.5 / 0.25 / 0.05 \mathrm{kcal} / \mathrm{mol})$, lipid heads $(5 / 5 / 2 / 1 / 0.2 / 0 \mathrm{kcal} / \mathrm{mol})$, and dihedral bonds $(500 / 200 /$ $100 / 100 / 50 / 0 \mathrm{kcal} / \mathrm{mol}$ ). Then, a production dynamics of $20 \mathrm{~ns}$ was carried out in NPT conditions at $303.15 \mathrm{~K}$ without any constraints.

Cell Culture. HeLa and HEK293 cells were grown at $37^{\circ} \mathrm{C}$ under $5 \% \mathrm{CO}_{2}$ in glucose-rich, Glutamax-I-containing Dulbecco's modified Eagle medium (DMEM) supplemented with $10 \%$ fetal bovine serum (FBS), $100 \mathrm{U} / \mathrm{mL}$ penicillin, and $100 \mu \mathrm{g} / \mathrm{mL}$ streptomycin.

Fibroblasts from Salla patients were obtained from the Finnish Institute for Health and Welfare (THL), Helsinki, Finland, and used in this study with ethical permission no. 78/13/03/00/16 (22 March 2016), issued by the Ethics Committee of the Helsinki and Uusimaa Hospital District, Finland. The fibroblasts tested for sialic acid storage rescue carried compound-heterozygote mutations in the SLC17AS gene: $115 \mathrm{c} \rightarrow \mathrm{t} / 1007-1008 \mathrm{del}$, corresponding to p.Arg39Cys/ p.Leu336Trpfs at the protein level. Fibroblasts were grown at 37 ${ }^{\circ} \mathrm{C}$ under $5 \% \mathrm{CO}_{2}$ in glucose-rich, Glutamax-I-containing DMEM supplemented with $20 \% \mathrm{FBS}, 100 \mathrm{U} / \mathrm{mL}$ penicillin, and $100 \mu \mathrm{g} / \mathrm{mL}$ streptomycin.

Expression of Recombinant Sialin. HeLa cells were transfected either by electroporation or lipofection. For electroporation, $2 \times 10^{6}$ HeLa cells in $50 \mu \mathrm{L}$ of ice-cold phosphate-buffer saline (PBS; pH 7.4) were mixed with $5 \mu \mathrm{g}$ of wild-type or R39C pEGFP-C2-sialin plasmid $^{6}$ and immediately subjected to 10 square pulses $(200 \mathrm{~V}, 3$ $\mathrm{ms}$ ) delivered at $1 \mathrm{~Hz}$ by a GHT 1287 electropulsator (Jouan) with 4 mm-spaced electrodes. Cells were then diluted with $7 \mathrm{~mL}$ of culture medium and distributed into 14 wells from a 24-well culture plate containing glass coverslips. For lipofection, HeLa were plated $(100,000$ cells/well) into 24 -well plates containing glass coverslips and transfected on the following day with Lipofectamine 2000 (Invitrogen) according to the manufacturer's protocol.

HEK 293 cells were plated (250,000 cells/well) into poly-D-lysinecoated 24-well plates and lipofected similarly with a construct carrying a sorting motif mutation ${ }^{6}$ (pEGFP-C2-sialin L22G/L23G) to express human sialin at the plasma membrane.
Radiotracer Flux Assays. $\mathrm{N}$-acetyl $\left[6-{ }^{3} \mathrm{H}\right]$ neuraminic acid $(20$ $\mathrm{Ci} / \mathrm{mmol})$ and $\left[4,5-{ }^{3} \mathrm{H}\right]$ Fmoc-L-leucine $(50 \mathrm{Ci} / \mathrm{mmol})$ were purchased from American Radiolabeled Chemicals. $\mathrm{L}-\left[1,2,1^{\prime}, 2^{\prime}{ }_{-}{ }^{14} \mathrm{C}\right]$ cystine $(200 \mathrm{mCi} / \mathrm{mmol})$ and $\mathrm{L}-\left[2,3,4,5-{ }^{3} \mathrm{H}\right]$-proline $(75 \mathrm{Ci} / \mathrm{mmol})$ were from PerkinElmer. $\left[{ }^{3} \mathrm{H}\right] \mathrm{Neu} 5 \mathrm{Ac}$ uptake into whole HEK293 cells was measured 2 days after transfection as described ${ }^{6}$ with minor changes. Cells were briefly washed and incubated for $15 \mathrm{~min}$ at room temperature with $\left[{ }^{3} \mathrm{H}\right]$ Neu5Ac $(12.5 \mathrm{nM} ; 0.05 \mu \mathrm{Ci} /$ well $)$ in a medium buffered with MES- $\mathrm{Na}^{+} \mathrm{pH}$ 5.0. After two brief ice-cold washes, the cellular radioactivity in the cells was counted by liquid scintillation with a Tri-Carb 4910TR counter (PerkinElmer). For classical experiments, inhibitors were added simultaneously with $\left[{ }^{3} \mathrm{H}\right]$ NeuSAc. However, for some experiments (Figure 6), inhibitors were pre-incubated for $15 \mathrm{~min}$ at $\mathrm{pH} 5.0$ followed by 15 or $30 \mathrm{~min}$ washes in a medium buffered at $\mathrm{pH} 7.0$ with $\mathrm{MOPS}-\mathrm{Na}^{+}$before measuring $\left[{ }^{3} \mathrm{H}\right] \mathrm{Neu} 5 \mathrm{Ac}$ transport. For saturation kinetics, incubation was shortened to $10 \mathrm{~min}$ to keep measurements within the linear phase of uptake at all $\left[{ }^{3} \mathrm{H}\right] \mathrm{Neu} 5 \mathrm{Ac}$ concentrations.

$\left[{ }^{3} \mathrm{H}\right]$-Fmoc-Leu-OH uptake was measured similarly using $2 \mu \mathrm{M}$ $\left(1 / 10\right.$ of $\left.\mathrm{IC}_{50}\right)$ and $0.05 \mu \mathrm{Ci} /$ well of the tracer. To compare FmocLeu-OH and Neu5Ac in Figure S1, $\left[{ }^{3} \mathrm{H}\right] \mathrm{Neu} 5 \mathrm{Ac}$ transport was measured at a similar transporter occupancy $(100 \mu \mathrm{M} ; 0.05 \mu \mathrm{Ci}$ / well).

Human cystinosin and rat LYAAT1 were assayed at the plasma membrane of HEK293 cells in MES- $\mathrm{Na}^{+} \mathrm{pH} 5.0$ buffer one day after lipofection using $\left[{ }^{14} \mathrm{C}\right]$ cystine $(20 \mu \mathrm{M} ; 0.08 \mu \mathrm{Ci} /$ well $)$ and $\left[{ }^{3} \mathrm{H}\right]$ proline $(100 \mu \mathrm{M} ; 0.1 \mu \mathrm{Ci} /$ well $)$ as substrates, respectively, as previously described. ${ }^{46,47}$

Immunofluorescence Analysis. Sialin distribution was analyzed 2 days after transfection as described. ${ }^{6}$ Cells were fixed with $4 \%$ paraformaldehyde. After quenching with $50 \mathrm{mM} \mathrm{NH}_{4} \mathrm{Cl}$ and several washes, cells were permeabilized and blocked with $0.05 \%$ saponin and $0.2 \%$ BSA in PBS buffer containing $\mathrm{Ca}^{2+}$ and $\mathrm{Mg}^{2+}$. Coverslips were then incubated for $\geq 1 \mathrm{~h}$ with mouse anti-LAMP1 antibodies (H4A3; Developmental Studies Hybridoma Bank) at $0.75 \mu \mathrm{g} / \mathrm{mL}$ in blocking buffer, washed, and incubated with Cy3-conjugated donkey antimouse antibodies (Jackson ImmunoResearch) at $1.4 \mu \mathrm{g} / \mathrm{mL}$ in the same buffer. Coverslips were then washed and mounted on glass slides with Fluoromount-G (SouternBiotech). Epifluorescence micrographs were acquired under a $100 \times$ objective lens with a Nikon Eclipse TE2000 microscope equipped with a CCD camera (Coolsnap). The intracellular distribution of recombinant sialin was classified into three categories (see Figure 8B) by an independent observer in a blind manner. In other experiments, sialin/LAMP1 colocalization was quantitated by assessing the spatial correlation between pixel intensities of the green and red channels. Dual-color images were imported into the Fiji version (http://fiji.sc) of Image J, ${ }^{63}$ and the Substract Background and Coloc 2 plugins were used to calculate Pearson's correlation coefficients across 20 to 25 cells/condition. Statistical analysis was made using Kruskal-Wallis nonparametric one-way ANOVA with post hoc Dunn's test. To test the effect of $\mathbf{4 5}$ on sialin localization, the compound was added during the transfection step. The 45-supplemented culture medium was replaced by a fresh one every day until $4 \mathrm{~h}$ before cell fixation.

Quantification of Sialic Acid Levels in Cells by Mass Spectrometry. Two confluent $75 \mathrm{~cm}^{2}$ flasks of human fibroblasts were used for each measurement. Cells were cultured for 2 days in the presence of 30 or $168 \mu \mathrm{M} 45$ in $0.3 \%$ DMSO or with DMSO alone for control at $37{ }^{\circ} \mathrm{C}$ under $5 \% \mathrm{CO}_{2}$. The 45 -supplemented culture medium was replaced by a fresh one twice. After the 2 days, cells were detached by trypsinization, washed with ice-cold PBS, and centrifuged. The resulting cell pellets were flash-frozen and kept at $-20{ }^{\circ} \mathrm{C}$ until measurement.

Sialic acid measurements were done with some differences in two laboratories. In one protocol, pellets were submitted to osmolysis by addition of $100 \mu \mathrm{L}$ of ultrapure water $\left(1 \mathrm{~h}, 4{ }^{\circ} \mathrm{C}\right)$ and subsequently sonicated $(3 \times 20 \mathrm{~s}$ with $10 \mathrm{~s}$ resting intervals $)$. At this stage, the protein concentration was determined for further normalization using Micro BCA Protein Assay Kit (ThermoFisher). After centrifugation (3000 rpm, $10 \mathrm{~min}, 4{ }^{\circ} \mathrm{C}$ ), three volumes of ice-cold $\mathrm{EtOH}$ were 
added to the supernatant and the mixture was kept overnight at -20 ${ }^{\circ} \mathrm{C}$ and centrifuged at $10,000 \mathrm{rpm}$ for $10 \mathrm{~min}$ to precipitate glycoproteins. The new supernatant (containing free saccharides) was dried under a nitrogen flow, while the new pellet was pooled with the previous one to extract protein- and lipid-bound saccharides. All samples were subsequently treated with $100 \mu \mathrm{L}$ of trifluoroacetic acid ((TFA) $0.1 \mathrm{M}, 2 \mathrm{~h}, 80^{\circ} \mathrm{C}$ ) for selective release of bound sialic acids and dried overnight into a vacuum concentrator (Concentrator 5301, Eppendorf). Dried samples were incubated with $50 \mu \mathrm{L}$ of the derivatization solution containing 1,2-diamino-4,5-methylenedioxybenzene dihydrochloride (DMB, $7 \mathrm{mM}$ ), 2-mercaptoethanol (1 M), $\mathrm{Na}_{2} \mathrm{~S}_{2} \mathrm{O}_{4}(18 \mathrm{mM})$, and TFA $(20 \mathrm{mM})$ for $2 \mathrm{~h}$ at $50{ }^{\circ} \mathrm{C}$ in the dark. Samples were kept at $-20{ }^{\circ} \mathrm{C}$ before analysis. Quantitative analyses were performed by micro-LC/ESI MRM-MS ${ }^{3}$ in the positive ion mode on an amaZon speed ETD ion trap mass spectrometer (Bruker Daltonics) equipped with a standard ESI source and controlled by Hystar software (ver. 3.2). The identification of $\mathrm{MS}^{2}$ fragment ions was based on previous papers. ${ }^{64,65} \mathrm{DMB}$-coupled sialic acid separation was achieved on Prominence LC-20AB micro LC system (Shimadzu). Samples were diluted 10 -fold in formic acid $(0.1 \%)$, and dilutions were applied $(5 \mu \mathrm{L})$ to a Luna $3 \mu \mathrm{m}$ analytical column $(\mathrm{C} 18,100 \AA$, $150 \times 1 \mathrm{~mm}$, Phenomenex) with isocratic elution in acetonitrile/ methanol/water $(4: 6: 90, \mathrm{v} / \mathrm{v} / \mathrm{v})$ at $60 \mu \mathrm{L} / \mathrm{min}$. Multiple reaction monitoring (MRM) of $\mathrm{MS}^{3}$ was used for DMB-coupled sialic acid quantification (ion spray voltage of $4500 \mathrm{~V}$; dry gas slow rate of $8 \mathrm{~L} /$ min). Absolute quantifications were calculated by comparing ion intensities to a standard curve established for DMB-coupled sialic acids (Neu5Ac, Neu5Gc, KDN). Results were normalized for the total protein amount (nmol of sialic acids/mg of protein).

In another protocol, $250 \mu \mathrm{L}$ of a $85 \mu \mathrm{mol} / \mathrm{L}$ solution of Neu $5 \mathrm{Ac}$ $1,2,3-{ }^{13} C_{3}$ (internal standard, IS; Sigma-Aldrich, ref no. 649694) was added to each fibroblast pellet. Samples were sonicated $(3 \times 10 \mathrm{~s}$ with $5 \mathrm{~s}$ resting intervals in ice) and assayed for protein concentrations. For free sialic acid, $100 \mu \mathrm{L}$ of this homogenate was mixed with $150 \mu \mathrm{L}$ of acetonitrile $(\mathrm{ACN})$, homogenized, and centrifuged. For the total sialic acid, $100 \mu \mathrm{L}$ of the homogenate was mixed with $200 \mu \mathrm{L}$ of sulfuric acid $(63 \mathrm{mM})$ and incubated for $1 \mathrm{~h}$ at $80^{\circ} \mathrm{C}$ for hydrolysis. Samples were supplemented with $450 \mu \mathrm{L}$ of $\mathrm{ACN}$, homogenized, and centrifuged. The two supernatants (free and bound sialic acid) were quantitated by LC/MS ${ }^{2}$ as described. ${ }^{66}$ Transitions $308.1>86.9$ (for Neu5Ac) and $311.1>89.9$ (for IS) were monitored with a declustering potential of $-50 \mathrm{~V}$ and a collision energy of $-16 \mathrm{~V}$. Peak integration was performed with Analyst software (version 1.6.2, Applied Biosystems; smoothing width: 3 points). Neu5Ac concentrations were calculated from the NeuSAc area/IS area ratio and the calibration curve (linear through zero) and normalized to protein concentrations.

\section{ASSOCIATED CONTENT}

\section{(s) Supporting Information}

The Supporting Information is available free of charge at https://pubs.acs.org/doi/10.1021/acs.jmedchem.9b02119.

Compound structure, abbreviations, and code numbers; synthesis scheme of Fmoc-amino acid 11, 12, 16, 22, 24, and 43; HPLC conditions and retention time for commercially available compounds; HPLC and HPLCMS spectra for compounds 3, 13, 45, 46, and 47; experimental details and analytical data for compounds 11, 12, 16, 22, 24-28, and 43; NMR spectra for compounds 45-47; Figures S1 to S5; Supplementary Methods; Supplementary References (PDF)

Molecular formula strings (SMILES) and associated data (CSV).

Sialin homology model docked with 45 (PDB)

\section{AUTHOR INFORMATION}

\section{Corresponding Authors}

Isabelle McCort-Tranchepain - Laboratoire de Chimie et Biochimie Pharmacologiques et Toxicologiques, CNRS, UMR 8601, Université de Paris, F-75006 Paris, France; 이이.org/ 0000-0001-7447-8806; Email: isabelle.mccort@ parisdescartes.fr

Bruno Gasnier - SPPIN - Saints-Pères Paris Institute for the Neurosciences, CNRS, Universite de Paris, F-75006 Paris, France; 이이. orcid.org/0000-0003-4458-6296; Email: bruno.gasnier@parisdescartes.fr

Christine Anne - SPPIN - Saints-Pères Paris Institute for the Neurosciences, CNRS, Universite de Paris, F-75006 Paris, France; Email: christine.anne@parisdescartes.fr

\section{Authors}

Lilian Dubois - Laboratoire de Chimie et Biochimie Pharmacologiques et Toxicologiques, CNRS, UMR 8601, Universite de Paris, F-75006 Paris, France

Nicolas Pietrancosta - Laboratoire des Biomolecules, LBM, Sorbonne Université, Ecole Normale Supérieure, PSL University, CNRS, F-75005 Paris, France; Neurosciences Paris Seine Institut de Biologie Paris Seine (NPS - IBPS), Sorbonne Universite, INSERM, CNRS, F-75005 Paris, France

Alexandre Cabaye - Laboratoire de Chimie et Biochimie Pharmacologiques et Toxicologiques, CNRS, UMR 8601, Universite de Paris, F-75006 Paris, France; BIOVIA, Dassault Systemes, F-78140 Velizy-Villacoublay, France

Isabelle Fanget - SPPIN - Saints-Peres Paris Institute for the Neurosciences, CNRS, Universite de Paris, F-75006 Paris, France

Cécile Debacker - SPPIN - Saints-Pères Paris Institute for the Neurosciences, CNRS, Universite de Paris, F-75006 Paris, France

Pierre-André Gilormini - UMR 8576, UGSF, Unité de Glycobiologie et Fonctionnelle, Université de Lille, CNRS, F59650 Lille, France

Patrick M. Dansette - Laboratoire de Chimie et Biochimie Pharmacologiques et Toxicologiques, CNRS, UMR 8601,

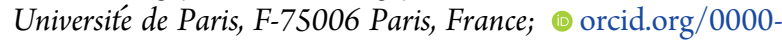
0002-3694-3348

Julien Dairou - Laboratoire de Chimie et Biochimie Pharmacologiques et Toxicologiques, CNRS, UMR 8601, Universite de Paris, F-75006 Paris, France

Christophe Biot - UMR 8576, UGSF, Unite de Glycobiologie et Fonctionnelle, Université de Lille, CNRS, F-59650 Lille, France; (1) orcid.org/0000-0002-7396-1959

Roseline Froissart - Service de Biochimie et Biologie Moleculaire Grand Est, Centre de Biologie et de Pathologie Est, Hospices Civils de Lyon, F-69677 Bron, France

Anne Goupil-Lamy - BIOVIA, Dassault Systemes, F-78140 Velizy-Villacoublay, France

Hugues-Olivier Bertrand - BIOVIA, Dassault Systèmes, F78140 Velizy-Villacoublay, France

Francine C. Acher - Laboratoire de Chimie et Biochimie Pharmacologiques et Toxicologiques, CNRS, UMR 8601,

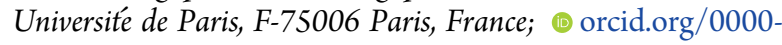
0002-5413-4181

Complete contact information is available at: https://pubs.acs.org/10.1021/acs.jmedchem.9b02119 


\section{Author Contributions}

F.A., I.M.-T., B.G., and C.A. designed the research. L.D., N.P., A.C., I.F., C.D., P.-A.G., R.F., I.M.-T., and C.A. conducted the experiments. All authors analyzed the data. F.A., I.M.-T., B.G., and C.A. wrote the paper.

\section{Funding}

This work was supported by the Agence Nationale de la Recherche (grant no. ANR-15-CE14-0001-02 to B.G.), the Association Nationale de la Recherche et de la Technologie (ANRT) and Dassault Systèmes BIOVIA (CIFRE PhD scholarship no. 2018/0027 to A.C.), the Ministère de l'Enseignement Supérieur, de la Recherche et de l'Innovation (PhD fellowship to P.-A.G.), the Neuropôle Région Ile-deFrance (PhD fellowship to L.D.), and the Science Ambassador Program from Dassault Systèmes BIOVIA (to A.C. and F.A.).

\section{Notes}

The authors declare no competing financial interest.

\section{ACKNOWLEDGMENTS}

We thank Dr. Aija Kyttälä from the Finnish Institute for Health and Welfare (THL) for acquiring the ethical permissions in Finland and providing Salla fibroblasts for this study. C.B. thanks the glycoconjugate analysis facility PAGes (http:// plateforme-pages.univ-lille1.fr) and the FRABio research federation.

\section{ABBREVIATIONS}

$\mathrm{Bz}$, benzoyl; Bzl, benzyl; Cbz, benzyloxycarbonyl; $\mathrm{t}$-Bu, tertbutyl; Boc, tert-butoxycarbonyl; CDI, 1,1'-carbonyldimidazole; DIEA, diethylamine; DMF, dimethylformamide; Fmoc, fluoren-9-ylmethoxycarbonyl; HBTU, 2-(1H-benzotriazol-1-yl)1,1,3,3-tetramethyluronium hexafluorophosphate; $\mathrm{MOMCl}$, methoxymethyl chloride; RT, room temperature; TFA, trifluoroacetic acid; THF, tetrahydrofuran; TMSCl, trimethylsilyl chloride; Trt, trityl

\section{REFERENCES}

(1) Reimer, R. J. SLC17: A Functionally Diverse Family of Organic Anion Transporters. Mol. Aspects Med. 2013, 34, 350-359.

(2) Iharada, M.; Miyaji, T.; Fujimoto, T.; Hiasa, M.; Anzai, N.; Omote, H.; Moriyama, Y. Type 1 Sodium-Dependent Phosphate Transporter (SLC17A1 Protein) Is a Cl-Dependent Urate Exporter. J. Biol. Chem. 2010, 285, 26107-26113.

(3) Blakely, R. D.; Edwards, R. H. Vesicular and Plasma Membrane Transporters for Neurotransmitters. Cold Spring Harbor Perspect. Biol. 2012, 4, a005595.

(4) Sawada, K.; Echigo, N.; Juge, N.; Miyaji, T.; Otsuka, M.; Omote, H.; Yamamoto, A.; Moriyama, Y. Identification of a Vesicular Nucleotide Transporter. Proc. Natl. Acad. Sci. U. S. A. 2008, 105, $5683-5686$

(5) Verheijen, F. W.; Verbeek, E.; Aula, N.; Beerens, C. E. M. T.; Havelaar, A. C.; Joosse, M.; Peltonen, L.; Aula, P.; Galjaard, H.; Van Der Spek, P. J.; Mancini, G. M. S. A New Gene, Encoding an Anion Transporter, Is Mutated in Sialic Acid Storage Diseases. Nat. Genet. 1999, 23, 462-465.

(6) Morin, P.; Sagnè, C.; Gasnier, B. Functional Characterization of Wild-Type and Mutant Human Sialin. EMBO J. 2004, 23, 45604570.

(7) Wreden, C. C.; Wlizla, M.; Reimer, R. J. Varied Mechanisms Underlie the Free Sialic Acid Storage Disorders. J. Biol. Chem. 2005, 280, 1408-1416.

(8) Qin, L.; Liu, X.; Sun, Q.; Fan, Z.; Xia, D.; Ding, G.; Ong, H. L.; Adams, D.; Gahl, W. A.; Zheng, C.; Qi, S.; Jin, L.; Zhang, C.; Gu, L.; He, J.; Deng, D.; Ambudkar, I. S.; Wang, S. Sialin (SLC17A5)
Functions as a Nitrate Transporter in the Plasma Membrane. Proc. Natl. Acad. Sci. U. S. A. 2012, 109, 13434-13439.

(9) Miyaji, T.; Echigo, N.; Hiasa, M.; Senoh, S.; Omote, H.; Moriyama, Y. Identification of a Vesicular Aspartate Transporter. Proc. Natl. Acad. Sci. U. S. A. 2008, 105, 11720-11724.

(10) Lodder-Gadaczek, J.; Gieselmann, V.; Eckhardt, M. Vesicular Uptake of $\mathrm{N}$-Acetylaspartylglutamate Is Catalysed by Sialin (SLC17A5). Biochem. J. 2013, 454, 31-38.

(11) Bardor, M.; Nguyen, D. H.; Diaz, S.; Varki, A. Mechanism of Uptake and Incorporation of the Non-Human Sialic Acid NGlycolylneuraminic Acid into Human Cells. J. Biol. Chem. 2005, 280, 4228-4237.

(12) Chou, H.-H.; Takematsu, H.; Diaz, S.; Iber, J.; Nickerson, E.; Wright, K. L.; Muchmore, E. A.; Nelson, D. L.; Warren, S. T.; Varki, A. A Mutation in Human CMP-Sialic Acid Hydroxylase Occurred after the Homo-Pan Divergence. Proc. Natl. Acad. Sci. U. S. A. 1998, 95, 11751-11756.

(13) Dhar, C.; Sasmal, A.; Varki, A. From "Serum Sickness" to "Xenosialitis": Past, Present, and Future Significance of the NonHuman Sialic Acid Neu5Gc. Front. Immunol. 2019, 10, 807.

(14) Kawanishi, K.; Dhar, C.; Do, R.; Varki, N.; Gordts, P. L. S. M.; Varki, A. Human Species-Specific Loss of CMP-N-Acetylneuraminic Acid Hydroxylase Enhances Atherosclerosis via Intrinsic and Extrinsic Mechanisms. Proc. Natl. Acad. Sci. U. S. A. 2019, 116, 16036-16045.

(15) Büll, C.; Heise, T.; Adema, G. J.; Boltje, T. J. Sialic Acid Mimetics to Target the Sialic Acid-Siglec Axis. Trends Biochem. Sci. 2016, 41, 519-531.

(16) Moons, S. J.; Adema, G. J.; Derks, M. T.; Boltje, T. J.; Büll, C. Sialic Acid Glycoengineering Using N-Acetylmannosamine and Sialic Acid Analogs. Glycobiology 2019, 29, 433-445.

(17) Aula, P.; Gahl, W. A. Disorders of Free Sialic Acid Storage. In The Metabolic Molecular Basis of Inherited Disease; Eighth Edition; Scriver, C. R., Beaudet, A. L., Sly, W. S., Valle, D., Childs, B., Kinzler, K. W., Vogelstein, B., Eds.; McGraw-Hill: New-York, 2001, pp 51095120.

(18) Aula, N.; Salomäki, P.; Timonen, R.; Verheijen, F.; Mancini, G.; Månsson, J.-E.; Aula, P.; Peltonen, L. The Spectrum of SLC17A5Gene Mutations Resulting in Free Sialic Acid-Storage Diseases Indicates Some Genotype-Phenotype Correlation. Am. J. Hum. Genet. 2000, 67, 832-840.

(19) Renlund, M.; Tietze, F.; Gahl, W. A. Defective Sialic Acid Egress from Isolated Fibroblast Lysosomes of Patients with Salla Disease. Science 1986, 232, 759-762.

(20) Varho, T. T.; Alajoki, L. E.; Posti, K. M.; Korhonen, T. T.; Renlund, M. G.; Nyman, S. R. G.; Sillanpää, M. L.; Aula, P. P. Phenotypic Spectrum of Salla Disease, a Free Sialic Acid Storage Disorder. Pediatr. Neurol. 2002, 26, 267-273.

(21) Zielonka, M.; Garbade, S. F.; Kölker, S.; Hoffmann, G. F.; Ries, M. A Cross-Sectional Quantitative Analysis of the Natural History of Free Sialic Acid Storage Disease-an Ultra-Orphan Multisystemic Lysosomal Storage Disorder. Genet. Med. 2019, 21, 347-352.

(22) Sonninen, P.; Autti, T.; Varho, T.; Hämäläinen, M.; Raininko, R. Brain Involvement in Salla Disease. Am. J. Neuroradiol. 1999, 20, 433-443.

(23) Prolo, L. M.; Vogel, H.; Reimer, R. J. The Lysosomal Sialic Acid Transporter Sialin Is Required for Normal CNS Myelination. J. Neurosci. 2009, 29, 15355-15365.

(24) Stroobants, S.; Van Acker, N. G. G.; Verheijen, F. W.; Goris, I.; Daneels, G. F. T.; Schot, R.; Verbeek, E.; Knaapen, M. W. M.; De Bondt, A.; Göhlmann, H. W.; Crauwels, M. L. A.; Mancini, G. M. S.; Andries, L. J.; Moechars, D. W. E.; D'Hooge, R. Progressive Leukoencephalopathy Impairs Neurobehavioral Development in Sialin-Deficient Mice. Exp. Neurol. 2017, 291, 106-119.

(25) Morland, C.; Nordengen, K.; Larsson, M.; Prolo, L. M.; Farzampour, Z.; Reimer, R. J.; Gundersen, V. Vesicular Uptake and Exocytosis of L-Aspartate Is Independent of Sialin. FASEB J. 2012, 27, 1264-1274. 
(26) Pitto, M.; Chigorno, V.; Renlund, M.; Tettamanti, G. Impairment of Ganglioside Metabolism in Cultured Fibroblasts from Salla Patients. Clin. Chim. Acta 1996, 247, 143-157.

(27) Aula, N.; Jalanko, A.; Aula, P.; Peltonen, L. Unraveling the Molecular Pathogenesis of Free Sialic Acid Storage Disorders: Altered Targeting of Mutant Sialin. Mol. Genet. Metab. 2002, 77, 99-107.

(28) Biancheri, R.; Rossi, A.; Verbeek, H. A.; Schot, R.; Corsolini, F.; Assereto, S.; Mancini, G. M. S.; Verheijen, F. W.; Minetti, C.; Filocamo, M. Homozygosity for the p.K136E Mutation in the SLC17A5 Gene as Cause of an Italian Severe Salla Disease. Neurogenetics 2005, 6, 195-199.

(29) Thompson, C. M.; Davis, E.; Carrigan, C. N.; Cox, H. D.; Bridges, R. J.; Gerdes, J. M. Inhibitor of the Glutamate Vesicular Transporter (VGLUT). Curr. Med. Chem. 2005, 12, 2041-2056.

(30) Pietrancosta, N.; Kessler, A.; Favre-Besse, F.-C.; Triballeau, N.; Quentin, T.; Giros, B.; El Mestikawy, S.; Acher, F. C. Rose Bengal Analogs and Vesicular Glutamate Transporters (VGLUTs). Bioorg. Med. Chem. 2010, 18, 6922-6933.

(31) Tamura, Y.; Ogita, K.; Ueda, T. A New VGLUT-Specific Potent Inhibitor: Pharmacophore of Brilliant Yellow. Neurochem. Res. 2014, 39, 117-128.

(32) Moriyama, Y.; Nomura, M. Clodronate: A Vesicular ATP Release Blocker. Trends Pharmacol. Sci. 2018, 39, 13-23.

(33) Pietrancosta, N.; Anne, C.; Prescher, H.; Ruivo, R.; Sagné, C.; Debacker, C.; Bertrand, H.-O.; Brossmer, R.; Acher, F.; Gasnier, B. Successful Prediction of Substrate-Binding Pocket in SLC17 Transporter Sialin. J. Biol. Chem. 2012, 287, 11489-11497.

(34) Huang, Y.; Lemieux, M. J.; Song, J.; Auer, M.; Wang, D.-N. Structure and Mechanism of the Glycerol-3-Phosphate Transporter from Escherichia Coli. Science 2003, 301, 616-620.

(35) Irwin, J. J.; Shoichet, B. K. ZINC - A Free Database of Commercially Available Compounds for Virtual Screening. J. Chem. Inf. Model. 2005, 45, 177-182.

(36) Jawalekar, A. M.; Meeuwenoord, N.; Cremers, J. S. G. O.; Overkleeft, H. S.; Van Der Marel, G. A.; Rutjes, F. P. J. T.; Van Delft, F. L. Conjugation of Nucleosides and Oligonucleotides by $[3+2]$ Cycloaddition. J. Org. Chem. 2008, 73, 287-290.

(37) Lin, W.; Long, L.; Feng, J.; Wang, B.; Guo, C. Synthesis of Meso-Coumarin-Conjugated Porphyrins and Investigation of Their Luminescence Properties. Eur. J. Org. Chem. 2007, 2007, 4301-4304.

(38) Shibu, E. S.; Ono, K.; Sugino, S.; Nishioka, A.; Yasuda, A.; Shigeri, Y.; Wakida, S. I.; Sawada, M.; Biju, V. Photouncaging Nanoparticles for MRI and Fluorescence Imaging in Vitro and in Vivo. ACS Nano 2013, 7, 9851-9859.

(39) Wirtz, L.; Kazmaier, U. A Mild Titanium-Catalyzed Synthesis of Functionalized Amino Coumarins as Fluorescence Labels. Eur. J. Org. Chem. 2011, 2011, 7062-7065.

(40) Kim, J. H.; Sumranjit, J.; Kang, H. J.; Chung, S. J. Discovery of Coumarin Derivatives as Fluorescence Acceptors for Intrinsic Fluorescence Resonance Energy Transfer of Proteins. Mol. BioSyst. 2014, 10, 30-33.

(41) Šebej, P.; Wintner, J.; Müller, P.; Slanina, T.; Al Anshori, J.; Antony, L. A. P.; Klán, P.; Wirz, J. Fluorescein Analogues as Photoremovable Protecting Groups Absorbing at $\sim 520 \mathrm{~nm}$. J. Org. Chem. 2013, 78, 1833-1843.

(42) Montalbetti, C. A. G. N.; Falque, V. Amide Bond Formation and Peptide Coupling. Tetrahedron 2005, 61, 10827-10852.

(43) Rudolf, K.; Eberlein, W.; Engel, W.; Pieper, H.; Entzeroth, M.; Hallermayer, G.; Doods, H. Development of Human Calcitonin Gene-Related Peptide (CGRP) Receptor Antagonists. 1. Potent and Selective Small Molecule CGRP Antagonists. 1-[N²-[3,5-Dibromo-N[[4-(3,4-Dihydro-2(1H)-Oxoquinazolin-3-Yl)-1-Piperidinyl]Carbonyl]-D-Tyrosyl]-1-Lysyl]-4-(4-Pyridinyl)piperazine: The First CGRP Antagonist for Clinical Trials in Acute Migraine. J. Med. Chem. 2005, 48, 5921-5931.

(44) Mali, S. M.; Ganesh Kumar, M.; Katariya, M. M.; Gopi, H. N. HBTU Mediated 1-Hydroxybenzotriazole ( $\mathrm{HOBt}$ ) Conjugate Addition: Synthesis and Stereochemical Analysis of $\beta$-Benzotriazole $N$ -
Oxide Substituted $\gamma$-Amino Acids and Hybrid Peptides. Org. Biomol. Chem. 2014, 12, 8462-8472.

(45) Vasko, R. C.; Rodriguez, R. A.; Cunningham, C. N.; Ardi, V. C.; Agard, D. A.; McAlpine, S. R. Mechanistic Studies of Sansalvamide AAmide: An Allosteric Modulator of Hsp90. ACS Med. Chem. Lett. 2010, 1, 4-8.

(46) Sagné, C.; Agulhon, C.; Ravassard, P.; Darmon, M.; Hamon, M.; El Mestikawy, S.; Gasnier, B.; Giros, B. Identification and Characterization of a Lysosomal Transporter for Small Neutral Amino Acids. Proc. Natl. Acad. Sci. U. S. A. 2001, 98, 7206-7211.

(47) Kalatzis, V.; Cherqui, S.; Antignac, C.; Gasnier, B. Cystinosin, the Protein Defective in Cystinosis, Is a $\mathrm{H}^{+}$-Driven Lysosomal Cystine Transporter. EMBO J. 2001, 20, 5940-5949.

(48) Bizzarri, R.; Arcangeli, C.; Arosio, D.; Ricci, F.; Faraci, P.; Cardarelli, F.; Beltram, F. Development of a Novel GFP-Based Ratiometric Excitation and Emission PH Indicator for Intracellular Studies. Biophys. J. 2006, 90, 3300-3314.

(49) Yan, N. Structural Biology of the Major Facilitator Superfamily Transporters. Annu. Rev. Biophys. 2015, 44, 257-283.

(50) Drew, D.; Boudker, O. Shared Molecular Mechanisms of Membrane Transporters. Annu. Rev. Biochem. 2016, 85, 543-572.

(51) Leano, J. B.; Batarni, S.; Eriksen, J.; Juge, N.; Pak, J. E.; KimuraSomeya, T.; Robles-Colmenares, Y.; Moriyama, Y.; Stroud, R. M.; Edwards, R. H. Structures Suggest a Mechanism for Energy Coupling by a Family of Organic Anion Transporters. PLoS Biol. 2019, 17, No. e3000260.

(52) Mancini, G. M.; Beerens, C. E.; Aula, P. P.; Verheijen, F. W. Sialic Acid Storage Diseases: A Multiple Lysosomal Transport Defect for Acidic Monosaccharides. J. Clin. Invest. 1991, 87, 1329-1335.

(53) Jones, G.; Willett, P.; Glen, R. C.; Leach, A. R.; Taylor, R. Development and Validation of a Genetic Algorithm for Flexible Docking. J. Mol. Biol. 1997, 267, 727-748.

(54) Kleta, R.; Aughton, D. J.; Rivkin, M. J.; Huizing, M.; Strovel, E.; Anikster, Y.; Orvisky, E.; Natowicz, M.; Krasnewich, D.; Gahl, W. A. Biochemical and Molecular Analyses of Infantile Free Sialic Acid Storage Disease in North American Children. Am. J. Med. Genet. 2003, 120A, 28-33.

(55) Robichaud, T.; Appleyard, A. N.; Herbert, R. B.; Henderson, P. J. F.; Carruthers, A. Determinants of Ligand Binding Affinity and Cooperativity at the GLUT1 Endofacial Site. Biochemistry 2011, 50, 3137-3148.

(56) Blat, Y. Non-Competitive Inhibition by Active Site Binders. Chem. Biol. Drug Des. 2010, 75, 535-540.

(57) Morello, J.-P.; Bouvier, M.; Petäjä-Repo, U. E.; Bichet, D. G. Pharmacological Chaperones: A New Twist on Receptor Folding. Trends Pharmacol. Sci. 2000, 21, 466-469.

(58) Parenti, G.; Andria, G.; Valenzano, K. J. Pharmacological Chaperone Therapy: Preclinical Development, Clinical Translation, and Prospects for the Treatment of Lysosomal Storage Disorders. Mol. Ther. 2015, 23, 1138-1148.

(59) The Uniprot Consortium. UniProt: A Worldwide Hub of Protein Knowledge. Nucleic Acids Res. 2019, 47, D506-D515.

(60) Thompson, J. D.; Higgins, D. G.; Gibson, T. J. CLUSTAL W: Improving the Sensitivity of Progressive Multiple Sequence Alignment through Sequence Weighting, Position-Specific Gap Penalties and Weight Matrix Choice. Nucleic Acids Res. 1994, 22, 4673-4680.

(61) Šali, A.; Blundell, T. L. Comparative Protein Modelling by Satisfaction of Spatial Restraints. J. Mol. Biol. 1993, 234, 779-815.

(62) Jo, S.; Kim, T.; Iyer, V. G.; Im, W. CHARMM-GUI: A WebBased Graphical User Interface for CHARMM. J. Comput. Chem. 2008, 29, 1859-1865.

(63) Schindelin, J.; Arganda-Carreras, I.; Frise, E.; Kaynig, V.; Longair, M.; Pietzsch, T.; Preibisch, S.; Rueden, C.; Saalfeld, S.; Schmid, B.; Tinevez, J.-Y.; White, D. J.; Hartenstein, V.; Eliceiri, K.; Tomancak, P.; Cardona, A. Fiji: An Open-Source Platform for Biological-Image Analysis. Nat. Methods 2012, 9, 676-682.

(64) Baumann, A.-M. T.; Bakkers, M. J. G.; Buettner, F. F. R.; Hartmann, M.; Grove, M.; Langereis, M. A.; De Groot, R. J.; Mühlenhoff, M. 9-O-Acetylation of Sialic Acids Is Catalysed by 
CASD1 via a Covalent Acetyl-Enzyme Intermediate. Nat. Commun. 2015, 6, 7673.

(65) Noel, M.; Gilormini, P.-A.; Cogez, V.; Yamakawa, N.; Vicogne, D.; Lion, C.; Biot, C.; Guérardel, Y.; Harduin-Lepers, A. Probing the CMP-Sialic Acid Donor Specificity of Two Human $\beta$-D-Galactoside Sialyltransferases (ST3Gal I and ST6Gal I) Selectively Acting on $O$ and N-Glycosylproteins. ChemBioChem 2017, 18, 1251-1259.

(66) Piraud, M.; Pettazzoni, M.; Menegaut, L.; Caillaud, C.; Nadjar, Y.; Vianey-Saban, C.; Froissart, R. Development of a New Tandem Mass Spectrometry Method for Urine and Amniotic Fluid Screening of Oligosaccharidoses. Rapid Commun. Mass Spectrom. 2017, 31, 951-963. 